\title{
PROPAGANDA, FISCALIDAD E IDEAL CRUZADISTA DURANTE EL REINADO DE ENRIQUE IV DE CASTILLA*
}

\author{
POR \\ PABLO ORTEGO RICO ${ }^{1}$ \\ Universidad de Málaga
}

\begin{abstract}
RESUMEN
Estudio de las concesiones de bula de cruzada para la lucha contra Granada otorgadas en 1455 y 1456 por el papa Calixto III a Enrique IV de Castilla, desde la perspectiva de la propaganda regia, y de los beneficios fiscales obtenidos por la monarquía castellana, con especial atención a la intervención de agentes financieros especializados, a la cuantificación del monto total obtenido, y a la instrumentalización del gasto como arma de difamación política.
\end{abstract}

PALABRAS CLAVE: Enrique IV de Castilla; papa Calixto III; bula de cruzada; indulgencias; fiscalidad; guerra de Granada; papado; Castilla; siglo XV.

\section{PROPAGANDA, TAXATION AND CRUSADING IDEAL DURING THE REIGN OF HENRY IV OF CASTILE}

\begin{abstract} Fifteenth century.

$\begin{array}{ll}\text { Recibido/Received } & 14-03-2016 \\ \text { Aceptado/Accepted } & 04-04-2016\end{array}$
\end{abstract}

Study of the concessions of the crusade indulgence for the fight against Granada granted in 1455 and 1456 by Pope Callixtus III to Henry IV of Castile, from the perspective of the royal propaganda and the tax benefits achieved by the Castilian monarchy, with a particular focus on the intervention of specialized fiscal agents, the quantification of the total amount obtained, and the exploitation of expenses as a weapon of political defamation.

KEY WORDS: Henry IV of Castile; Pope Callixtus III; Bull of the Crusade; indulgences; taxation; Granada war; Papacy; Castile;

Cómo CITAR ESTE ARTículo / CITATION: Ortego Rico, P. 2018. «Propaganda, fiscalidad e ideal cruzadista durante el reinado de Enrique IV de Castilla». Hispania Sacra 70, 141: 237-266. https://doi.org/10.3989/hs.2018.019

\footnotetext{
*Este trabajo forma parte de los siguientes Proyectos de Investigación financiados por el Programa Estatal de Fomento de la Investigación Científica y Técnica de Excelencia (Subprograma Estatal de Generación de Conocimiento) del Ministerio de Economía y Competitividad, «Expresiones de la cultura política peninsular en las relaciones de conflicto (Corona de Castilla, 1230-1504)» (HAR2016-76174-P), «El negocio de la fiscalidad: gestión tributaria, redes financieras y grupos de poder en la Corona de Castilla (1450-1550)» (HAR2013-45788-C4-1-P), «Prácticas de comunicación y negociación en las relaciones de consenso y pacto de la cultura política castellana. Ca. 1230-1504» (HAR2013-42211-P) y
}

«Poder, fiscalidad y sociedades fronterizas en la Corona de Castilla al sur del Tajo (siglos XIV-XVI)» (HAR2014-52469-C3-1-P). Siglas y abreviaturas utilizadas: $\mathrm{ACB}=$ Archivo Catedral de Burgos; $\mathrm{AGS}=$ Archivo General de Simancas; $\mathrm{AMMU}=$ Archivo Municipal de Murcia; ARCV = Archivo de la Real Chancillería de Valladolid; $C p=$ carpeta; $C R=$ Cartulario Real; $C S R$ = Casa y Sitios Reales; doc. = documento; EMR = Escribanía Mayor de Rentas; exp. = expediente; f. $/ \mathrm{ff} .=$ folio/folios; $\mathrm{mrs}=$ maravedíes; $\mathrm{PR}=$ Patronato Real; RGS = Registro General del Sello; RR = Libros de Registro; SNAHN = Sección Nobleza del Archivo Histórico Nacional.

1 portego@uma.es/ORCIDiD: http://orcid.org/0000-0002-1780-4633 


\section{INTRODUCCIÓN}

La participación de la monarquía castellana en fuentes de renta cuya aprobación dependía del pontificado constituye uno de los aspectos fundamentales en la redefinición de las relaciones entre ambas instancias observada a fines de la Edad Media, tendentes a consolidar una situación de intervencionismo en los asuntos de la Iglesia por parte de la Corona como parte del proceso de construcción del llamado "Estado moderno». ${ }^{2}$ Es bien sabido que, desde el siglo XIII, los reyes de Castilla venían aprovechando en su favor diversos recursos de origen eclesiástico (tercias reales, préstamos, décimas y subsidios), amparándose fundamentalmente en argumentos de tipo político-religioso, que legitimaban las demandas de apoyo económico presentadas ante las instancias eclesiásticas para afrontar la lucha contra el infiel. ${ }^{3}$ En este sentido, la ampliación de la doctrina sobre las indulgencias incrementó las posibilidades de financiación de los fines de la monarquía a partir de la entrega de limosnas por parte de los fieles, autorizadas por los pontífices y aplicadas bajo control de la Corona a la guerra peninsular contra el infiel -considerada en términos de cruzada o "guerra santa»-, a cambio de la remisión de sus culpas, en virtud de la capacidad reconocida al papa para destinar a la salvación del alma los méritos de Cristo y de los santos, acumulados en el "tesoro de la Iglesia». Estos conceptos -cruzada, limosna e indulgencia - seguían conformando en el siglo XV la base sobre la cual se construía el discurso legitimador de esta importante fuente de renta, a pesar de la decadencia del ideal cruzadista que se observa desde fines del siglo XIII —en paralelo a la pérdida de protagonismo político del pontificado ligada al fin de sus pretensiones universalistas-, y de los primeros debates en torno a la validez de las indulgencias ya presentes en esta época. ${ }^{4}$

La ausencia de concesiones de bula de cruzada que se observa durante los reinados de los tres primeros monarcas trastámara (1369-1406), frente a su mayor operatividad en la época de la llamada "Batalla de Estrecho» desarrollada entre los reinados de Alfonso $\mathrm{X}$ y Alfonso $\mathrm{XI}^{5}$, dio paso durante los años de la minoría de Juan II a una revitalización de la capacidad de la monarquía castellana para percibir el producto de las cruzadas y subsidios otorgados por los papas, con el objetivo teórico de financiar la empresa granadina, tal y como ya se pudo observar a raíz de la campaña del infante don Fernando para la conquista de Antequera (1410). ${ }^{6}$ No obstante, conviene no perder de vista que muchas de las concesiones obtenidas por Juan II tras alcanzar la mayoría de edad en 1418 hay que valorarlas en el marco político posterior al Concilio de Constanza (1414-1418), y más ade-

\footnotetext{
2 Nieto Soria 1993.

3 Para una panorámica general sobre la intervención del poder regio en las rentas eclesiásticas en el contexto de los reinos hispánicos y Francia ver Morelló i Baget 2013. Para Castilla es fundamental la visión de conjunto, incluida en este último volumen, aportada por Villarroel González 2013: 315-343. Para el ámbito francés ver el trabajo de Causse 1988.

4 Sobre la bula de cruzada en Castilla sigue siendo imprescindible la consulta de la obra clásica de Goñi Gaztambide 1958. Ver también las consideraciones sobre cruzadas, subsidios y décimas en su aplicación específica al caso castellano entre mediados del siglo XIII y finales del XV en Ladero Quesada 2011: 196-202; ibídem 2009a: 229-241; Nieto Soria 1988a: 123-130: ibídem 1993: 322-337; Villarroel González 2013: 327-332.

5 Ver, sin ánimo de ser exhaustivo, O'Callaghan 2011.

6 González Sánchez 2013: 214-216.
}

lante como resultado del conflicto existente en el seno de la Iglesia, evidenciado tras la deriva conciliarista adoptada por el Concilio de Basilea inaugurado en febrero de 1431, en un contexto condicionado por la necesidad que el pontificado tenía de contar con la ayuda del rey de Castilla para hacer valer sus posiciones. Estas circunstancias, apoyadas por la reanudación de la guerra contra Granada en momentos puntuales, y ocasionalmente como instrumento de propaganda política ${ }^{7}$, llevó a una multiplicación de las concesiones y renovaciones de cruzada durante el reinado efectivo de Juan II (1421, 1430-1431, 1433, 1437-1438, 1448 y 1452), cuyos resultados económicos no siempre fueron los esperados. ${ }^{8}$

\section{CONCESIONES PAPALES Y PROPAGANDA MONÁRQUICA EN TORNO A LA CRUZADA A COMIENZOS DEL REINADO DE ENRIQUE IV (1455-1457)}

El inicio del reinado de Enrique IV de Castilla en julio de $1454^{9}$ vino acompañado de una nueva revitalización de la lucha contra el emirato nazarí, cuyos objetivos políticos trascendieron desde el primer momento la dimensión estrictamente militar del conflicto, al tiempo que marcaron un nuevo hito en la ampliación de los beneficios fiscales y en términos de propaganda asociados a las concesiones papales de bula de cruzada. Ya en el transcurso de un ayuntamiento celebrado en Cuéllar y Segovia en febrero de 1455, el rey expuso - tras recibir la obediencia de ciudades, nobleza y clero-, su programa político. En él se incluía casi como único punto la reanudación de las campañas contra Granada como forma de pacificar el reino, canalizando hacia un objetivo común la voluntad de las diferentes facciones nobiliarias que hasta entonces habían pugnado por mediatizar el poder regio. ${ }^{10} \mathrm{El}$ "razonamiento» expuesto por el rey ante los procuradores reunidos - recogido por Diego Enríquez del Castillo-, incide en esta idea presentando una efectista argumentación en torno a los beneficios que la guerra contra el infiel tendría para el mantenimiento de la unidad y paz del reino. ${ }^{11}$ Coincide el cronista Alonso de Palencia en las intenciones de Enrique IV - asignando su habitual matiz negativo- cuando refiere por boca del contador mayor Diego Arias Dávila la dimensión política asignada a la campaña, ya que "tanto las querellas del pueblo como las maquinaciones de los levantiscos magnates quedarían acalladas al solo apellido de guerra contra los granadinos». ${ }^{12}$

Además de la pacificación del reino, las campañas contra el emirato nazarí desarrolladas entre abril y julio de 1455 en forma de quemas y talas sobre la Vega de Granada y la Hoya de Málaga ${ }^{13}$, también permitirían fortalecer el liderazgo

\footnotetext{
7 Así se pudo observar tras la victoria castellana de La Higueruela (1431), ligada a la proyección política del privado regio don Álvaro de Luna. Nieto Soria 2010: 389-404.

8 Análisis de las condiciones políticas bajo las cuales Juan II recibió subsidios y cruzadas en Villarroel González 2011: 326-330; ibídem 2013: 327-332; Nieto Soria 1993: 326-327; ibídem 1994: 113-131; Arranz Guzmán 2006: 281-285. Goñi Gaztambide 1958: 345-351.

9 Sobre el reinado enriqueño ver Suárez Fernández 2001; Martín Martín 2002.

10 Arranz Guzmán 2006: 288.

11 Enríquez del Castillo 1994: 146-147.

12 Palencia 1973: I, 64

13 Sobre estas campañas ver Ladero Quesada 2002: 43; Suárez Fernández 2001: 149-151; O’Callaghan 2014: 95-100.
} 
de Enrique IV, y dotar de legitimidad los mecanismos extraordinarios de captación de nuevos recursos fiscales utilizados por el monarca durante la primera década de su reinado, con independencia de que su destino final fuese realmente la lucha contra el infiel. Para lograr ambos objetivos el monarca utilizó todos los resortes políticos a su alcance, empezando por la convocatoria en 1455 de una reunión de Cortes celebrada en Córdoba. En su transcurso el rey pudo hacer visible el consenso de los procuradores en torno a su proyecto político, explicitado mediante la concesión de un servicio bianual de $71.000 .000 \mathrm{mrs}$ (31.000.000 mrs para 1455 y 40.000 .000 mrs para 1456) destinado a sufragar los gastos de las futuras campañas contra Granada. ${ }^{14} \mathrm{El}$ mismo apoyo obtuvo el rey de los nobles, en cuya boca pone Palencia un encendido discurso en el que se exalta la temprana determinación de Enrique, tras su providencial acceso al trono, por acabar con la presencia de infieles en la Península, circunstancia que aportaba una legitimad «de ejercicio» al desempeño del oficio regio heredado. ${ }^{15}$

No obstante, la posibilidad de contar con el apoyo expreso del pontificado, a partir de la consideración como cruzada de las campañas lanzadas contra el emirato nazarí, se reveló como un eficaz instrumento para incrementar el prestigio del monarca mediante la construcción de una cierta imagen de "rey cruzado» ${ }^{16}$, pero también para obtener nuevos recursos, en forma de limosnas aportadas por los súbditos y de exacciones sobre las rentas eclesiásticas de Castilla. ${ }^{17}$ Así lo habría entendido el contador mayor Diego Arias Dávila que, según Alonso de Palencia, aseguró al rey que los posibles gastos de las acciones bélicas emprendidas contra Granada podrían "convertirse en ganancia» si ordenaba sufragar su coste mediante nuevos repartimientos personales de impuestos, y además «impetraba del papa Nicolás V, tan complaciente con los Reyes, una indulgencia, únicamente valedera para los que espontáneamente contribuyesen con quince reales de plata para la expedición ». ${ }^{18}$ Según esta concepción, la verdadera relevancia de las campañas - que en opinión de Palencia, no eran sino un ejercicio de "simulación»- no se encontraría en los éxitos militares, ni tan siquiera en los beneficios territoriales logrados a costa del emirato nazarí, sino en su potencial uso como instrumento de legitimación de las exacciones fiscales. ${ }^{19}$

Al margen de la manipulación a la que, como veremos, sometió el cronista el asunto de la cruzada, lo cierto es que Enrique IV mostró un temprano interés, quizás a iniciativa de Diego Arias Dávila y del marqués de Villena, por obtener del pontificado toda una serie de concesiones que permitiesen dotar de un marcado carácter religioso las campañas que esperaba realizar. Así lo expresaron los embajadores

14 Olivera Serrano 1986: 71-72. La Crónica anónima de Enrique IV señala el interés del monarca en el otorgamiento de nuevos «pedidos» y «monedas», "porque para el año venidero oviese dinero para bolver fazer guerra a los moros», a pesar de que - a decir del cronista- los procuradores eran conscientes de que el desarrollo del tipo de guerra que ya habían podido observar en la campaña inicial no consumiría la totalidad del servicio solicitado. Sánchez Parra 1991: 45-46.

15 Palencia 1973: I, 65.

16 Echevarría Arsuaga 2004: 143-156.

17 Nieto Soria 1996: 174-175.

18 Palencia 1973: I, 64.

19 Ibídem: I, 86 y 93. castellanos enviados en 1455 ante Calixto III, nuevo papa de origen valenciano y sucesor de Nicolás $\mathrm{V}^{20}$, cuyo discurso trató de persuadir al pontífice de los beneficios que el éxito de Enrique IV ante al emirato nazarí podía ofrecer más adelante frente a la expansión de los turcos en el Mediterráneo oriental, a la que el monarca castellano sabría poner freno una vez vencidos los granadinos. Por lo tanto, a tenor de este argumento, convenía al papa auxiliar económicamente a Enrique, para lo cual no sería necesario destinar dinero de la Cámara Apostólica, sino «el que se sacase del espontáneo tesoro de las indulgencias que a los fieles se concedieran $» .^{21}$ Tras la primera concesión de una bula de cruzada el 20 de abril de 1455 , a la que nos referiremos más adelante, una segunda embajada castellana enviada en 1456 - siguiendo la recomendación de una asamblea de nobles celebrada en Ávila a finales de $1455^{22}$ - presionó a Calixto III a fin de que no demorase más el otorgamiento de una nueva bula de indulgencia más generosa. En este sentido, los enviados de Enrique IV fundamentaron su petición, por un lado, en el rotundo éxito de las campañas militares llevadas a cabo el año anterior, solo posibles gracias a la «liberalidad de la Santa Sede», y por otro, en la necesidad -más teórica que real- de emplear artillería y recursos navales, mucho más costosos, para el asedio de las plazas fuertes y la interrupción del apoyo en forma de suministro prestado a Granada por los reinos musulmanes del Norte de África. ${ }^{23}$

Tal y como ha señalado Nieto Soria, es evidente que el contexto político internacional existente al acceder Enrique IV al trono facilitó la aprobación de concesiones pontificias particularmente favorables a los intereses fiscales de la monarquía sobre el clero y la Iglesia castellana, amparadas en la movilización general de la cristiandad contra el avance turco fomentada desde el papado a raíz de la toma de Constantinopla en 1453. Su expresión más destacada en aquel momento sería el voto de tomar la cruz realizado por Calixto III tras su elección, y el posterior intento de colaboración entre el papa y Alfonso $V$ de Aragón para lanzar una expedición naval contra el enemigo mahometano, ahogado a la postre en maniobras dilatorias y conflictos internos. ${ }^{24}$ No obstante, la ineficacia económica y militar de estos llamamientos a nivel europeo tuvo como contrapunto el relativo éxito - al menos desde el punto de

20 Sobre Calixto III es imprescindible la consulta del exhaustivo trabajo de Navarro Sorní 2008a. También las colecciones diplomáticas publicadas sobre su figura, especialmente aquellas referidas a los años de su pontificado. Navarro Sorní 2008b. López Rodríguez 2007. Sobre los Borgia existe una abundantísima bibliografía que, habida cuenta de la falta de espacio, no es posible citar, ni siquiera de forma somera. No obstante, sigue siendo útil, para una panorámica general, el trabajo clásico de Batllori 1999.

21 Palencia 1973: I, 64-65.

22 El relato de esta asamblea nobiliaria presentado por Diego de Valera incurre en diversos errores, pues sitúa esta reunión a finales de 1454, cuando realmente debió tener lugar entre comienzos de noviembre y mediados de diciembre de 1455, y menciona a Nicolás V como sucesor de Calixto III. Valera 1941: 9. Enrique IV estuvo en Ávila entre el 5 de noviembre de 1455 y antes de la Navidad del mismo año. Torres Fontes s/a: 78-82.

23 Palencia 1973: I, 86-87. Sobre esta embajada ver el análisis crítico de Nieto Soria 1996: 174-175 y Echevarría Arsuaga 2004: 148-149.

24 Los aspectos relativos a la cruzada contra el Turco en tiempos de Calixto III en Navarro Sorní 2008a: 377-570; ibídem 2004: 147-167. Ver también Valentini 1974: 91-123. 
vista financiero- de la cruzada predicada en Castilla, cuyo ámbito de aplicación específico quedó circunscrito a la particular guerra contra el infiel librada en la Península que, en definitiva, era una amenaza mucho más próxima que la representada por el Turco. ${ }^{25}$

Entre 1455 y 1457 Calixto III aprobó al menos diez bulas en apoyo de la empresa de Enrique IV - no todas de indulgencia-, de las cuales las más importantes a efectos fiscales fueron las concedidas el 20 de abril de 1455 y el 14 de abril de $1456 .{ }^{26}$ La otorgada en 1455 , con una validez de cuatro años desde la fecha de su publicación, reconocía la remisión de sus pecados a todos aquellos que combatiesen en la guerra de Granada, así como a los fieles que contribuyesen con una limosna de 3 florines de Aragón o 200 mrs. ${ }^{27}$ De este modo, se daba continuidad al progresivo descenso en el precio tasado para las limosnas aplicadas a la cruzada desde la época de Juan II: de los 12 florines establecidos inicialmente en 1431 , se pasó a 5 florines en $1433^{28}$, y a 3 florines en las concesiones de $1448^{29}$ y 1455. El objetivo no era otro que mejorar el rendimiento fiscal de las campañas de predicación mediante una ampliación de la base social de los posibles compradores de bulas, hasta el momento integrada casi de forma exclusiva por los grupos dotados de mayor capacidad adquisitiva que, además, siempre podrían utilizar la toma de la bula como instrumento para publicitar su compromiso con la lucha contra el infiel. ${ }^{30}$

La primera concesión calixtina de cruzada fue ampliada el 14 de abril de 1456 bajo unas condiciones novedosas que autorizaban por primera vez la extensión de los beneficios espirituales «a las ánimas que están en Purgatorio, las quales fueren nonbradas por los fieles en las yndulgençias que tomaren pagando por cada una d'ellas la sobre dicha suma de dinero para ayuda contra los moros». ${ }^{31}$ Estas "amplias facultades

25 Nieto Soria 1993: 328; ibídem 1996: 171-179 y 207-210.

26 Echevarría Arsuaga 2004: 149.

27 Rius Serra 1948: I, 67-69.

28 Goñi Gaztambide 1958: 345. Villarroel González 2011: 328-329. Nieto Soria 1993: 326. Según un registro de documentación pontificia en el año octavo del libro De divissis beneficiis figuraba la reducción de la limosna de la cruzada de 8 ducados a 5 florines de Aragón, además de la comisión dada a ciertos prelados para que castigasen «los que falsean los sygilos de las dichas bullas». Villarroel González 2000: 182. Según el libro de "recepta» de la Real Hacienda castellana desde 1431 la limosna ascendía a 5 florines. AGS, EMR, leg. 1, f. 130.

29 Goñi Gaztambide 1958: 351.

30 Sabemos, por ejemplo, que la infanta Isabel - futura Isabel Itomó una bula firmada el 4 de diciembre de 1458. AGS, PR, leg. 19, doc. 2. Por su parte, el marqués de Villena Juan Pacheco, tomó una bula firmada el 30 de septiembre de 1457. SNAHN, Frías, Cp. 259, doc. 4.

31 Así consta, por ejemplo, en el traslado romanceado de la bula realizado para el concejo de Murcia. AMMU, CR, no 798bis, ff. 64v-65r. Análisis de estas concesiones en Nieto Soria 1993: 329-330; ibídem 1996: 175; Goñi Gaztambide 1958: 358-363; ibídem 1954: 377-391. Las cartas dadas a los receptores de la cruzada desde 1457 para su presentación ante los concejos recuerdan que el papa había concedido «su Santa Cruzada e bulla de indulgençia plenaria con muy grandes e favorables graçias tales que en memoria de los que son bivos non se falla averse otorgado otras semejantes», de la cual podrían beneficiarse tanto aquellos que acudiesen en persona a combatir como los que pagasen, por sí o para sus difuntos, una limosna de 200 mrs destinada al pago del sueldo de los efectivos movilizados, y de los "pertrechos» y artillería que teóricamente serían destinados a la contienda granadina. AGS, EMR, leg. 8, ff. 924-925. para la recaudación del dinero $»^{32}$ incrementaron los beneficios económicos de la concesión, a pesar de los debates relativos a la validez de las indulgencias otorgadas a los finados, de los cuales se hace eco el cronista Palencia ${ }^{33}$. Pese a la controversia despertada, lo cierto es que las dudas sobre la capacidad del papa para autorizar dichas indulgencias fueron resueltas, según la Crónica anónima, de forma favorable a los intereses fiscales de la monarquía, en virtud de las competencias reconocidas al pontífice para absolver a las almas del Purgatorio, argumentadas en la localización física de este espacio en la tierra, y por lo tanto situado bajo la jurisdicción espiritual de los sucesores de San Pedro. ${ }^{34}$ En este sentido, conviene recordar que la polémica en torno a la posibilidad de extender las indulgencias a las almas del Purgatorio a partir de los méritos acumulados por la Iglesia contaba con un largo recorrido que arranca del siglo XIII, aunque hasta 1312 (Concilio de Vienne) no hubo una condena oficial a la remisión de las penitencias a los difuntos, considerada como práctica abusiva. No obstante, el debate se reavivó en el siglo XV en un contexto marcado por la reflexión en torno a las atribuciones y misión del pontífice posterior a la salida del Cisma y la crisis conciliarista abierta en el Concilio de Basilea. ${ }^{35}$

Al margen de estos debates, lo cierto es que el 6 de enero de 1457 Enrique IV recibía en Palencia con gran solemnidad, y en compañía de los prelados que con él estaban, la bula de la cruzada "para bivos e muertos quel Papa Calisto terçero le enbio». La concesión fue predicada en la corte el día de la Candelaria (2 de febrero) por el confesor real fray Alonso de Espina ${ }^{36}$, que se convertiría a partir de este momento en firme defensor de la validez de las indulgencias y de la cruzada enriqueña, según expresa en su Fortalitium Fidei, redactado hacia $1460 .{ }^{37} \mathrm{~A}$ pesar de la parquedad del relato presentado por las crónicas, lo cierto es que los ritos celebrados con

32 Palencia 1973: I, 93.

33 Palencia señala cómo «Diego Arias trató de acallar las murmuraciones de los que negaban fuese católica la aplicación [de las indulgencias] a los difuntos, y de los muchos que decían no tener facultades el Papa para decretar semejantes sufragios por dinero». Palencia 1973: I, 93.

34 Sánchez Parra 1991: 65.

35 Sobre el debate en Castilla en torno a las indulgencias de difuntos ver Baloup 2003-2004: 61-89.

36 Sánchez Parra 1991: 65. Valera 1941: 41. Alonso de Palencia recoge la recepción de la bula en la ciudad de Palencia «con solemne pompa» y su predicación posterior «por teólogos». Palencia 1973: I, 93. En efecto, a tenor de los datos del itinerario regio el monarca estuvo en Palencia al menos hasta el 9 de febrero de 1457. Torres Fontes s./a.: 99-102. Los relatos cronísticos son corroborados por la documentación diplomática. La carta de receptoría de la cruzada del infantazgo de Valladolid dada a Diego Rodríguez de Dueñas, mercader vecino de Valladolid, en Segovia el 30 de mayo de 1457, señala que el rey recibió la bula «con los perlados e grandes de mis reynos que conmigo estavan en la çibdad de Palençia, con aquella solepnidad e proçesiones que a tan eçelente abto convenía». AGS, EMR, leg. 8, ff. 924-925. Por su parte, la Vida del Cardenal D. Pedro González de Mendoza, escrita por Francisco de Medina y Mendoza, señala erróneamente la recepción de la bula en Plasencia - quizás por un error de transcripción-, aunque sitúa la predicación de la indulgencia por fray Alonso de Espina el día de la Candelaria. Medina y Mendoza 1853: vol. VI, 158-159.

37 La negación de la eficacia de las indulgencias aparece en el catálogo de catorce prácticas heréticas señaladas en el Fortalitium Fidei por Alonso de Espina. Goñi Gazambide 1980: 29-30. No obstante, la validez de las indulgencias aplicadas a los difuntos fue puesta en duda por el franciscano. Nieto Soria 1993: 330. La visión apologética sobre la cruzada otorgada por Calixto III a Enrique IV, y la guerra contra Granada expuesta en el Fortalitium Fidei en Echevarría Arsuaga 2004: 155-156. 
motivo de la recepción de este tipo de bulas terminaron por convertirse en un elemento frecuente dentro del aparato ceremonial desplegado por los monarcas de la dinastía trastámara durante el siglo XV. Así se había podido constatar el 3 de junio de 1431 tras la recepción en Córdoba de la bula de cruzada otorgada a Juan II por Martín V ${ }^{38}$, y volvería a observarse tras la recepción y publicación el 20 de abril de 1483 en Madrid de la bula concedida en 1482 por Sixto IV a los Reyes Católicos para la guerra final contra Granada. ${ }^{39}$

Inmediatamente se puso a trabajar toda la maquinaria burocrática y propagandística que permitiría, por un lado, iniciar las labores de recaudación de las limosnas aportadas por los fieles, y por otro, profundizar en la consolidación del liderazgo político del monarca a partir de la construcción y difusión, dentro y fuera de Castilla, de una imagen carismática como «rey cruzado» que prolongaba las atribuciones asociadas al ideal de rey cristianísimo-rey guerrero. ${ }^{40}$ Para contribuir a tal propósito, el 25 de febrero de 1457 el papa permitía a Enrique IV llevar el emblema de la cruz - que sería impuesto por el arzobispo de Sevilla, siguiendo el ceremonial utilizado por el papa para la bendición e imposición de las insignias de la cruzada contra el Turco- y utilizar el pendón de la cruzada $^{41}$, portado tradicionalmente por el ejército castellano en las principales campañas contra el Islam a las que el papado había asignado tal consideración, como las de 1340 (batalla del Salado), 1410 (campaña de Antequera) o 1431 (batalla de La Higueruela). ${ }^{42}$ Ambos elementos reforzaban desde el punto de vista simbólico y ceremonial el perfil político-religioso que la Corona deseaba proyectar como defensora de la cristiandad, y el respaldo papal a una empresa militar que - según el discurso regio- trascendía el ámbito estrictamente castellano. Este apoyo se vio ampliado el 25 de marzo de 1458, cuando Enrique IV recibió con todo boato en el alcázar de Madrid, y en presencia de la corte, una espada y una «ínsula» (ensis) o sombrero cesáreo bendecidos por Calixto III en la Misa de Gallo de 1457, enviados junto

38 Carrillo de Huete 1946: 100; Barrientos 1946: 119.

39 Pulgar 1943: II, 50. La fecha exacta de la recepción y publicación de la bula aparece recogida en AGS, RGS, abril de 1485, f. 51.

40 Nieto Soria 1988b: 80-81.

41 Rius Serra 1948: II, doc. 2792; Goñi Gaztambide 1958: 365; Nieto Soria 1996: 175. El arzobispo de Sevilla también sería el encargado de poner la insignia a todos los combatientes - nacionales o extranjerosque lo solicitasen.

42 El pendón de la cruzada ya había sido utilizado por Alfonso XI en la batalla del Salado, tras ser otorgado en 1340 por el papa junto con la bula de cruzada y una décima. Fernández Gallardo 2010: 63-64. Fue utilizado de nuevo por el infante don Fernando en el cortejo procesional realizado el 1 de octubre de 1410 en Antequera, tras la toma de la ciudad, con el que se inició la ceremonia de bendición de la mezquita del castillo. Abrían la comitiva los «pendones de la Cruzada e del señor Sant Isidro de León e el de Santiago, e sus pendones». Carriazo y Arroquia 1982: 394. También encontramos el uso ceremonial de los pendones de la cruzada - uno colorado y otro blanco, portados respectivamente por dos escuderos de Fernán Arias de Saavedra, alférez de la cruzada-, en la entrada triunfal realizada por el infante don Fernando en Sevilla tras la toma de Antequera. Ibídem: 399-400. Sobre esta ceremonia ver Nieto Soria 2012a: II, 1694-1695. Más adelante, en la batalla de La Higueruela de 1431 encontramos el pendón de la cruzada, portado por don Alfonso de Estúñiga, caballero de la casa de don Álvaro de Luna, junto al pendón del rey y el pendón de la orden de la Banda. Carriazo 1940: 137. Por su parte, la Crónica anónima de Enrique IV señala que ganarían las indulgencias recogidas en la bula de Calixto III aquellos que entrasen a su costa en tierra de moros con el rey de Castilla «o debaxo del pendon de la Cruzada, con entençion e proposyto de les fazer guerra». Sánchez Parra 1991: 66. con un breve por el papa a Castilla con su familiar Pedro Roldán o Rolla, probablemente gracias a la mediación de Rodrigo Sánchez de Arévalo. Con ello el papa distinguía la especial dedicación del monarca a la lucha contra el infiel, tratando quizás de vincularlo a su fallido proyecto de cruzada contra el Turco ${ }^{43}$ pues, como señala el cronista Enríquez del Castillo en su relato de la recepción de ambos presentes, «tan varonilmente se avia [mostrado] en defensión de la Fe católica e aumento de ella». ${ }^{44}$

Más allá de la imagen mostrada a través de la diferente simbología ligada a la cruzada, lo cierto es que en los primeros meses de 1457 el llamamiento a la lucha contra el infiel en Granada se propagó más allá de las fronteras castellanas. Así lo refleja el relato escrito por el caballero suabo Jörg von Ehingen que, estando en la corte portuguesa en el transcurso de su periplo como «caballero andante» por tierras hispanas, tuvo noticia de la intención que albergaba Enrique IV de «capitanear una gran cruzada contra el Rey moro de Granada, como la proyectada con anterioridad, cuando nos hallábamos en la capital de Francia, que no se verificó a consecuencia de cierta peste», a la cual deseaba unirse, como así sucedió. ${ }^{45}$ Del mismo modo, la cruzada concedida al monarca castellano tuvo un impacto notable en el vecino reino de Aragón, que también aportó combatientes para la lucha contra el emirato nazarí, lo que podría entenderse como un éxito de la propaganda ligada al Ilamamiento. ${ }^{46}$ Sin embargo, los intentos de Enrique IV por extender la recaudación de limosnas a la Corona aragonesa resultaron infructuosos. Así se desprende de las evasivas dadas el 22 de marzo de 1459 por Juan II de Aragón al monarca castellano en respuesta a una carta portada por el guarda Diego del Castillo, enviada con evidentes fines fiscales, en la que solicitaba permiso para publicar en los territorios aragoneses

43 Benito Ruano 1960: 268-269; Nieto Soria 1996: 176-177. A la información - no siempre fidedigna - aportada por el cronista Galíndez de Carvajal, hay que añadir el relato de la recepción en la corte enriqueña de la espada y el sombrero papales realizado por el autor de los Hechos del Condestable Miguel Lucas de Iranzo, que sitúa correctamente el episodio en el alcázar real de Madrid el 25 de marzo de 1458. Cuevas Mata y Arco Moya 2001: 3. El breve de Calixto III a Enrique IV (25 de enero de 1458) enviado con los presentes solicitaba además la concesión del hábito de Santiago para Pedro Rolla. AGS, PR, leg. 60, doc. 3. Memorias de don Enrique IV de Castilla. Vol. II. Colección diplomática. 1835-1913: 155-156. El estoque se conservaba, con la signatura G-5, en la Real Armería de Madrid. Según la descripción del catálogo de 1898, «en cada lado de la hoja lleva un escudo circular con un toro en campo de roeles, encimado por la tiara y las llaves, que son las armas de este Pontífice, y a continuación esta leyenda: ACCIPE $\cdot S \cdot$ GLADIVM $\cdot$ MVNVS

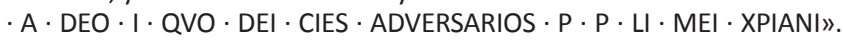
Conde de Valencia de Don Juan 1898: 189-190.

44 Enríquez del Castillo 1878: 108.

45 Fabié 1879: 41. Análisis del viaje de Jörg von Ehingen en Salicrú i Lluch 2004: 224-226.

46 Así lo constata un documento de abril de 1457, en el que se menciona el flujo de fieles catalano-aragoneses que habían decidido acudir "a la sancta cruada contra los enemichs de la fe»; la carta dirigida el 1 de abril del mismo año por la reina María de Aragón a Huesca en respuesta a las denuncias por las irregularidades cometidas por los colectores en esta ciudad, los cuales se negaban a sufragar con las limosnas aportadas por los fieles los gastos del camino de aquellos que habían decidido tomar la cruz, así como a darles las armas que les habían sido entregadas; o la orden dada por la misma reina el 20 de abril de 1457 a los oficiales y vasallos del reino de Aragón y el Principado de Cataluña para que todos aquellos que desearan combatir contra el infiel recibieran salvoconducto y la llicència d'acapte que les facultaba para pedir limosnas de forma legal. Salicrú i Lluch 1998: 468-469. 
la cruzada «contra los moros del regno de Granada, enemigos de nuestra santa fe catolica» concedida por el papa. ${ }^{47}$

Para la difusión interna en Castilla de los fundamentos que legitimaban la convocatoria papal, el rey se valió, entre otros instrumentos, de las cartas libradas desde mayo de 1457 en favor de los receptores encargados de recaudar las limosnas, en las cuales se despliega toda la panoplia de argumentos con los que la monarquía trató de incentivar las aportaciones económicas de sus súbditos. ${ }^{48}$ Estas misivas comienzan resaltando los éxitos militares alcanzados contra el emirato nazarí por Enrique IV tras su acceso al trono, en el marco de una "guerra justa» destinada a recuperar las villas, castillos y fortalezas ocupadas por «el rey e moros del regno de Granada, enemigos de nuestra fe católica», y castigar los daños, robos, prisiones y muertes realizados contra los súbditos castellanos. Todo ello reforzaba la imagen de Enrique IV y su capacidad para liderar personalmente una campaña providencial revestida de caracteres sagrados..$^{49}$ En este sentido, el monarca trataba de forjar un amplio consenso en torno a un proyecto en el que, según se afirmaba, habían participado «muchos de los grandes» del reino y "otra asaz gente», embarcados junto al monarca en las expediciones de hostigamiento lanzadas desde 1455 contra el emirato nazarí, fundamentalmente en forma de operaciones de desgaste - talas y quemas de cosechas y heredades - con el objetivo de asfixiar económicamente Granada en un momento de inestabilidad interna. ${ }^{50}$ No obstante, el sostenimiento de los medios militares teóricamente movilizados - gentes de armas, jinetes, peones, artillería, armadas y «pertrechos de guerra por mar e por tierra»- habría dejado de ser viable toda vez que, siempre a tenor del contenido de estas cartas, ya se habían consumido los recursos destinados hasta el momento a la contienda, entre ellos el "pedido» y «monedas» otorgado por las Cortes para el bienio 1455-1456, y las elevadas sumas extraídas del tesoro regio.

A esta supuesta falta de medios económicos motivada por los grandes dispendios realizados en las campañas previas, que la propaganda regia consideraba un auténtico éxito, y a la tradicional consideración del conflicto con Granada como empresa «justa e santa» - que además permitiría liberar a los vasallos y naturales de Castilla cautivos en el emirato-, se sumaba un argumento novedoso, empleado para reforzar la vinculación de la cruzada concedida para la guerra de Granada con el llamamiento papal que afectaba a toda la cristiandad. Se trata de la conmoción causada por

47 El motivo alegado era la necesidad de consultar en el contexto del Concilio convocado en Mantua desde el verano de 1459 por Pío II, sucesor de Calixto III en el pontificado, «sobre ciertas cosas fazientes por semeiantes indulgencias». Giménez Soler 1908: 374.

48 Tomamos como modelo la carta de receptoría de la Santa Cruzada del infantazgo de Valladolid dada a Diego Rodríguez de Dueñas, mercader vecino de Valladolid, en Segovia el 30 de mayo de 1457. AGS, EMR, leg. 8, ff. 924-925. Ver también la carta enviada al concejo de Murcia el 4 de febrero de 1458, que presenta un formulario semejante. Benito Ruano 1960: 295-299.

49 La carta señala cómo «por la graçia de nuestro Señor son avidos e recobrados algunos de los dichos castillos e fortalezas que asy avían tomado e de los suyos avido otros algunos». Asimismo, Enrique IV justifica la autorización de la cruzada por el papa «por la continuaçión de la dicha guerra, e porque mediante la graçia de nuestro Señor la entiendo seguir contra los dichos moros por ser cosa tanto nesçesaria e conplidera a serviçio de Dyos e mío, e ensalçamiento de nuestra Santa Fe Católica».

50 La actividad militar contra Granada entre 1455 y 1458 puede seguirse en Ladero Quesada 2002: 42-46; O'Callaghan 2014: 93-103. la toma de Constantinopla el 29 de mayo de 1453 a manos de los turcos, a la que se sumaban las tropelías contra fieles, iglesias, reliquias y ornamentos llevadas a cabo por los invasores en la antigua capital bizantina, y el temor que generaba la posibilidad de la expansión otomana hasta Italia y la misma Roma, con sus dramáticas consecuencias para toda la cristiandad. ${ }^{51}$ Esta última motivación también serviría para legitimar en 1456 la aprobación por parte del papa de un subsidio de 200.000 florines sobre las rentas eclesiásticas, complementario al rendimiento de la cruzada, rebajado el 15 de octubre de 1457 a instancias de Enrique IV a 100.000 florines tras las quejas del clero castellano - mitad para la Real Hacienda y mitad para las arcas pontificias-. Su destino teórico sería la lucha contra el Turco, aunque también podría emplearse en la guerra contra el emirato nazarí. ${ }^{52}$

En definitiva, las «imágenes» tópicas que circulaban sobre el Turco - apoyadas fundamentalmente en las ideas de barbarie, depravación y crueldad $^{53}-$, fueron aprovechadas en Castilla para tratar de consolidar, en un contexto emocional particularmente propicio para la recepción de este tipo de mensajes, un estado de opinión favorable a la captación de nuevos recursos económicos destinados a una empresa, como la granadina, integrada desde esta perspectiva en un proyecto político global, legitimado y liderado desde el papado. Ciertamente, en un primer momento esta idea pudo calar en amplios sectores sociales según evidencia, por ejemplo, la mención al «subsidio de los çient mill florines que nuestro señor el papa otorgó al señor rey para ayuda de la guerra contra los moros», incluida en el acta del cabildo burgalés celebrado el 23 de septiembre de 1457, en el cual se nombró a los procuradores que acudirían a la asamblea en la que tendría lugar el reparto por diócesis de esta cantidad. ${ }^{54}$ No obstante, el éxito de la propagada ligada a la justificación de los nuevos beneficios en materia fiscal obtenidos por la monarquía - especialmente en relación al subsidio- pronto quedó en entredicho como consecuencia de los desequilibrios observados en la distribución de la carga fiscal y las protestas lanzadas de forma abierta por el clero castellano en algunas diócesis desde $1458 .{ }^{55}$

51 «...nuestro muy Santo Padre visto esto e los grandes males e dapnos qu'el grand Turco e los moros que con él andavan fezieron en el Inperio de Constantinopola e como se apoderaron d'ella e mató mucha gente de los christianos e derribó todas las yglesias e quemó todas las santas reliquias e ornamentos d'ellas e las tornó mezquitas, tanto que fue a tienpo de llegar a Roma e de se apoderar d'ella e de toda Ytalia siguiendo guerra contra la Christiandad a fin de la estruyr».

52 Nieto Soria 1993: 330-331. Previamente ya se había notificado a algunas diócesis su concesión. Así lo evidencia la entrega realizada por el cabildo burgalés el 12 de septiembre de 1457 de 50 mrs a un escudero de Alonso de Fonseca, arzobispo de Sevilla, encargado de llevar a Burgos unas cartas «sobre el susidio que echó nuestro señor el papa». ACB, RR-16, f. 1 . El 18 de octubre del mismo año se reunía en Olmedo una congregación de la Iglesia del reino, encargada de realizar el reparto de los 100.000 florines atendiendo a la riqueza y nivel de renta de cada diócesis. Nieto Soria 1993: 331.

53 Las diferentes ideas acerca del Turco presentes en la literatura castellana posterior a la toma de Constantinopla - especialmente las mostradas por Rodrigo Sánchez de Arévalo en su De sceleribus Turchi, escrito antes de 1469- han sido analizadas por Fernández Gallardo 2014: 475-495.

54 ACB, RR-2, f. 226v.

55 Así se aprecia, por ejemplo, en la denuncia sobre lo excesivo de los repartimientos del subsidio presentada en octubre de 1458 por el deán de la catedral de Córdoba. SNAHN, Luque, C. 584, doc. 17. 


\section{LA LOGÍSTICA DE LAS CAMPAÑAS DE PREDICACIÓN DE LA CRUZADA}

Al margen de la problemática específica del subsidio - que no abordaremos de forma detallada-, los aspectos burocráticos de la cruzada quizás sean uno de los elementos peor conocidos de las concesiones papales de 1455 y $1456^{56}$, a pesar de su importancia para calibrar el grado de control ejercido por la monarquía sobre el discurso político-religioso puesto en circulación y sobre los recursos económicos obtenidos. En este sentido, el nombramiento de Alonso de Fonseca, arzobispo de Sevilla, oidor de la Audiencia Real y referendario regio, como comisario general ${ }^{57}$ con el cometido de dirigir y coordinar las campañas de predicación de la indulgencia, resulta especialmente sintomático del fuerte intervencionismo de la monarquía en los asuntos de la cruzada, en virtud de la adscripción del prelado al círculo de colaboradores más próximo a Enrique IV. ${ }^{58}$ Ello garantizaba a la Corona un control directo sobre los aspectos logísticos, plasmado en la ausencia de cualquier decisión pontificia en materia de gestión, a pesar del envío a Castilla del nuncio apostólico y colector Antonio Jacobo de Veneris para, entre otras cosas, fiscalizar junto al obispo de Ciudad Rodrigo fray Alonso de Palenzuela, el uso dado a las limosnas autorizadas por el papa. ${ }^{59}$

A las órdenes de Fonseca actuaron por delegación diversos oficiales responsables de la ingente tarea de copiar, firmar y sellar las cartas de bula ofrecidas a los fieles, así como de ejercer el control contable sobre las remesas entregadas, que debían quedar asentadas por los contadores mayores en los libros del rey a fin de evitar «falta nin colusión nin encubierta alguna». ${ }^{60}$ Tal y como consta en las relaciones de remesas de bulas entregadas a los receptores o a sus apoderados, habitualmente se ocupó de firmar las cartas de bula, en nombre del arzobispo de Sevilla, el cronista y secretario del latín del rey Alonso de Palencia. Esta circunstancia explicaría su acceso a información de primera mano referida a la cruzada, instrumentalizada posteriormente en su relato cronístico con el objetivo de desprestigiar la imagen de Enrique IV. ${ }^{61}$ No obstante, en una fase avanzada de las campañas de predicación también intervinieron los secretarios del arzobispo de Sevilla Juan de Arévalo - desde diciembre de 1458 hasta marzo de $1462^{62}$ - y especialmente Fernando de Arce que, entre marzo de 1461 y junio de 1462, firmó algunas de las partidas

56 Tan solo contamos con las referencias de Ladero Quesada 2009a: 230.

57 Así figura en la bula de Santa Cruzada otorgada por Calixto III a Enrique IV, expedida en favor de Juan Pacheco por el arzobispo de Sevilla, comisario general, el 30 de septiembre de 1457. SNAHN, Frías, Cp. 259, doc. 4. También en las cartas remitidas a los concejos con los receptores nombrados para la recaudación. AGS, EMR, leg. 8, ff. 924-925.

58 Ver su perfil prosopográfico en Nieto Soria 1993: 436.

59 Sobre la labor de Veneris como nuncio ver Nieto Soria 1996: $175-$ 176 y 188-189. A pesar de que su intervención en la gestión de la cruzada fue prácticamente inexistente, Veneris tuvo un papel mucho más destacado en las labores de control de los subsidios concedidos por el papa a lo largo de estos años.

60 AGS, EMR, leg. 8, ff. 924-925.

61 Palencia 1973: I, 93.

62 Aparece por primera vez firmando bulas en el asiento correspondiente a la entrega de 986 cartas de bula realizada el 17 de diciembre de 1458 al receptor Diego de Soria. AGS, EMR, leg. 8, f. 1057. La última mención a Juan de Arévalo la encontramos en el asiento correspondiente a la entrega de 300 cartas de bula realizada el 5 de marzo de 1462 al receptor García Martínez de Lerma. AGS, EMR, leg. 8, ff. 935-940 y 1052. de bulas entregadas a los receptores. ${ }^{63}$ Además de la rúbrica de los delegados del comisario general, cada carta de bula también debía ser validada con el sello confeccionado ex profeso para la cruzada, «el qual es de la una parte un castillo e de la otra parte una cruz doblada», a fin de evitar cualquier tipo de falsificación. ${ }^{64}$

Por debajo, y en el marco de cada uno de los distritos fiscales en los que se dividía el reino a efectos de recaudación, actuaban los diferentes receptores/tesoreros. Estos agentes eran los encargados de recibir las cartas de bula que se distribuirían posteriormente a los fieles, de organizar la predicación, de recibir el monto recaudado a partir de las limosnas, y de acometer los pagos ordenados por el rey mediante cartas de libramiento y albalaes. La provisión de los oficios de receptoría de la cruzada era potestad exclusiva del monarca, sin que mediara, como sucedía en el caso de las rentas ordinarias, un proceso de licitación previo. Una vez notificado al interesado su nombramiento mediante carta librada por los contadores mayores, este debía «obligar» sus bienes muebles y raíces "por maravedíes e aver del dicho señor rey». No obstante, para mayor garantía ante el impago, en ocasiones, al igual que era preceptivo en los arrendamientos de las rentas ordinarias, los receptores también tuvieron que presentar fiadores para asegurar con sus bienes las sumas comprometidas con la Corona. ${ }^{65}$ En cualquier caso, cada receptor debía comparecer ante el escribano de cámara del rey y notario público Gonzalo García de Llerena - hombre perfectamente integrado en el organigrama burocrático de la monarquía ${ }^{66}$ y encargado de la gestión de muchos aspectos relativos a la bula de cruzada entre 1457 y 1462-, para asumir formalmente, mediante carta de «obligación» y juramento ante testigos, los compromisos asociados al oficio de receptoría, bajo pena de confiscación de bienes y de incurrir en las censuras señaladas en las bulas dadas por el papa en caso de incumplimiento. Posteriormente, Gonzalo García de Llerena notificaba a los contadores mayores mediante "recaudo» la obligación presentada por cada receptor. ${ }^{67}$

63 Fernando de Arce figura por primera vez como firmante de bulas en el asiento correspondiente a la entrega de una remesa de bulas realizada el 17 de marzo de 1461 al receptor Juan González de Nieva, vecino de Santa María de Nieva. La última referencia a su actividad aparece en la entrega de bulas realizada al mismo receptor el 21 de junio de 1462 . AGS, EMR, leg. 8, ff. 1048-1051.

64 AGS, EMR, leg. 8, ff. 924-925.

65 Uno de los asientos de la cuenta de Diego Rodríguez de Dueñas, receptor del infantazgo de Valladolid, menciona a Francisco de Valladolid, trapero, como «su fiador». AGS, EMR, leg. 8, ff. 1053-1054.

66 Su perfil prosopográfico en Cañas Gálvez 2012: 342-343.

67 Ver, por ejemplo, el "recaudo» de la receptoría de la Santa Cruzada de las villas de Medina del Campo, Arévalo, Olmedo, Madrigal, Alaejos, Castrejón, Valdefuentes, Bobadilla, y sus tierras, dada a Alfón Arias, hijo de Juan Álvarez de Mercado, vecino de la villa de Arévalo, dado por Gonzalo García de Llerena el 14 de junio de 1457. AGS, EMR, leg. 8, ff. 920-921. La mecánica de gestión descrita ya se encontraba en vigor durante la campaña de predicación de la cruzada de 1431. Según el libro de "recepta» de las rentas regias, Juan II encomendó inicialmente a fray Lope de Medina, obispo de Segovia, el sellado de las cartas de indulgencia que fuese necesario dar para la cruzada, entregadas posteriormente a Juan Fernández de Treviño y a Gonzalo Rodríguez de Argüelles, contadores del rey, que serían los encargados de remitirlas a los tesoreros de la cruzada nombrados al efecto, a cambio de recibir obligación «de cómo las resçibían para las dar a las personas que las quisiesen tomar pagando cada persona los dichos çinco florines». AGS, EMR, leg. 1, f. 130. 
Estos «recaudos»-que siguen, con pequeñas variaciones, un mismo formulario- permiten conocer por primera vez para Castilla el marco normativo que regía el funcionamiento interno, organización y desarrollo de las campañas de predicación. ${ }^{68}$ Cada receptor se comprometía a pagar al rey, sin mediar ningún tipo de descuento, embargo o "toma», $150 \mathrm{mrs}$ por cada una de las cartas de bula recibidas del comisario o sus delegados, aunque se aceptaría el «descargo» de aquellas bulas no colocadas. Las sumas obtenidas tras la venta de las indulgencias debían ser puestas, bajo pena del doblo, en la cámara del rey "a su aventura e costa e misión» de tres en tres meses desde el día en que el receptor, u otra persona apoderada en su nombre, recibiese las cartas de bula, o antes si ya hubiese recaudado las limosnas. Asimismo, cada receptor también se obligaba a dar a los contadores mayores, de tres en tres meses, copia "çierta e verdadera» de las cartas de bula distribuidas, a fin de tener constancia del estado en el que se encontraba la recaudación. Finalmente, los receptores se comprometían a distribuir únicamente las cartas de bula recibidas de los contadores mayores, evitando cualquier fraude, y a impedir la publicación o predicación de otras bulas e indulgencias lesivas al rendimiento económico de la cruzada en vigor.

Los 50 mrs que faltaban hasta completar los 200 mrs establecidos como limosna en la concesión papal permanecerían en poder de cada receptor para abonar los derechos que, según orden regia, debían percibir el arzobispo de Sevilla - comisario general-, los contadores mayores, y otras personas contenidas en cierto albalá asentado en los libros de los contadores. El cobro de estos derechos fue aprovechado años más tarde por Alonso de Palencia para atacar la figura del contador mayor Diego Arias Dávila, inductor de la medida según el cronista, y de los cortesanos que supuestamente se estaban beneficiando de una concesión cuyo rendimiento habría sido sistemáticamente desviado de su legítimo destino. Entre estos últimos se contarían el arzobispo de Sevilla, que percibía una cantidad por cada bula firmada; la dama portuguesa doña Guiomar de Castro, supuesta amante del rey y beneficiaria de los derechos «del sello» de las bulas; y el propio contador mayor, que se habría reservado "otra porción más considerable», quedando para el «erario real la dobla con que cada uno había de contribuir». ${ }^{69} \mathrm{Al}$ margen de las consideraciones de Palencia, lo cierto es que, a tenor de los "recaudos» conservados, este $25 \%$ de cada limosna también servía para sufragar diferentes aspectos logísticos, entre ellos el salario de los receptores por «el resçibir e recabdar de los dichos mrs», los gastos ocasionados por el traslado de estas cuantías a la cámara regia, las «despensas» de los predicadores ${ }^{70}$, y los desembolsos realizados en la compra de los «pendones e tronpetas» utilizados en las ceremonias de publicitación de la indulgencia.

Las labores de propaganda religioso-política asociadas a la cruzada también ocupaban un lugar destacado entre los

68 AGS, EMR, leg. 8, ff. 1032-1033.

69 Palencia 1973: I, 93.

70 Alonso de Espina criticó en su Fortalitium Fidei el aprovechamiento económico del rendimiento de la cruzada realizado por muchos predicadores que «más bien son mercenarios» ya que «se ajustan para recaudar el dinero de ciertas bulas como si fueran operarios que se contratan en las plazas para cultivar viñas, de tal manera que reciben un tanto por cada bula que despachan». Goñi Gaztambide 1958: 367. compromisos organizativos asumidos por los agentes designados por la monarquía. De esta forma, cada receptor era el encargado, por un lado, de poner en su distrito fiscal buenos predicadores - «los mejores que pudiere aver y tantos quantos bastaren»- responsables de distribuir entre los fieles la mayor cantidad posible de bulas, y por otro, de hacer que estos últimos recorrieran todas las villas, lugares y aldeas de la circunscripción a su cargo, junto a él o sus delegados, «publicando e faziendo que se predique la dicha indulgençia de la dicha Santa Cruzada». De igual forma, en cada villa o lugar el receptor se comprometía a entregar a personas «llanas e contiosas»-es decir, solventes económicamenteun número de bulas suficiente para su venta posterior a "los que las quisieren resçebir estando enfermos o en vida, o para el artyculo de la muerte», lo cual suponía extender la colaboración en la campaña más allá del estamento clerical.

No obstante, más allá de las menciones genéricas incluidas en los "recaudos», apenas tenemos datos sobre la actuación y el contenido de los sermones pronunciados por los predicadores, cuyo papel en la difusión del ideario político que legitimaba la petición de limosnas y de los argumentos teológicos y religiosos en los cuales se basaba la remisión de los pecados ofrecida era esencial, tal y como ha puesto de relieve D. Baloup. ${ }^{71}$ Tan solo conocemos la actividad desarrollada en Sevilla por el confesor real fray Alonso de Espina que, a decir de Diego Ortiz de Zúñiga, «atenía en sus sermones a persuadir a los fieles como se habian de aprovechar de la Cruzada» ${ }^{72}$ y, como se recordará, ya se había encargado previamente de predicar la indulgencia en la corte enriqueña tras la recepción de la bula por el monarca a comienzos de 1457.

Otras cláusulas, incluidas en los «recaudos» emitidos desde finales de 1457, momento en el que la campaña ya contaba en algunas circunscripciones con un recorrido de varios meses, denuncian algunos de los fraudes más generalizados. Así, había predicadores y religiosos que ofrecían a personas carentes de recursos económicos la posibilidad de recibir la absolución sin que mediara la entrega de la correspondiente bula, abonando parte del precio establecido para la limosna, con objeto de apropiarse posteriormente de estas sumas en connivencia con los agentes que tenían a su cargo los oficios de tesorería. En otros casos, los predicadores trataban de recuperar «por dineros e de graçia» - es decir, gratuitamente- las cartas de bula ya vendidas, convenciendo a los fieles que las habían tomado de que, una vez absueltos, ya no necesitarían conservarlas. A continuación, estas cartas recobradas eran vendidas a receptores, predicadores, clérigos y otras personas que, tras una nueva reventa posterior, podrían extraer un rendimiento extra al margen de la contabilidad oficial. Ambos fraudes atentaban gravemente "contra el thenor e forma de las bullas apostólicas [...] y en deserviçio de Dios, e en menospreçio de nuestra Santa Fee, e en grand dapno de la dicha Santa Cruzada». Por ello, para combatirlos la Corona exigió a los receptores el desempeño de labores de control que incluían el apremio a los predicadores para que en sus sermones advirtiesen de tales prácticas; la inspección de la labor de estos últimos; y la notificación al rey de

\footnotetext{
71 Baloup 2003: 315-323; ibídem 2003-2004: 79-88.

72 Ortiz de Zúñiga 1796: III, 12.
} 
cualquier irregularidad detectada, previo encarcelamiento de los infractores y embargo de sus bienes. ${ }^{73}$

La labor desempeñada por receptores y predicadores, cada uno en su ámbito competencial, era complementada con el apoyo prestado por los poderes concejiles en una doble vertiente: por un lado, facilitando el soporte logístico necesario para la predicación y cobro de las indulgencias; por otro, contribuyendo a la difusión en el escenario local de los argumentos que legitimaban la petición de las limosnas. Consciente de la importancia que tenía para el desarrollo exitoso de las campañas de predicación la cooperación de las autoridades concejiles, como correa de transmisión de las órdenes regias y del discurso elaborado desde la Cancillería, la Corona remitió a las villas cabecera de cada circunscripción cartas informando de la identidad de los receptores, de las condiciones de recaudación, y de la finalidad que se daría a las sumas percibidas. ${ }^{74}$ Estas misivas complementaban el contenido de las bulas papales, cuyos traslados romanceados - se conservan los realizados para el concejo de Murcia ${ }^{75}$ - contribuían a difundir un discurso político-religioso semejante, al tiempo que facilitaban a las autoridades locales información directa sobre los beneficios espirituales aprobados por el papa, a fin de evitar fraudes.

Las cartas enviadas por el rey ponen especial énfasis en el solemne recibimiento en forma de cortejo procesional, "con las cruzes e reliquias e ornamentos de las yglesias cathedrales e perrochias, tañiendo las canpanas de todas las dichas iglesias», que las autoridades concejiles debían dispensar tras su llegada a cada localidad, tanto a los religiosos encargados de publicar y predicar la cruzada, como a los otros clérigos y legos responsables de recaudar las limosnas, y de portar la bula y los pendones reales y trompetas que la acompañaban. Esta conjunción de elementos ceremoniales reforzaba la legitimidad del acto refrendado por las autoridades eclesiásticas y concejilesy contribuía a crear en los fieles un estado emocional favorable a la entrega de limosnas condicionado por la vistosidad del ambiente simbólico y sonoro creado, y por la oratoria desplegada posteriormente desde el púlpito por los predicadores. Asimismo, resulta especialmente significativa la aparición del pendón real en estas ceremonias como forma de resaltar el especial patrocinio ejercido por la Corona sobre la cruzada a través de la presencia simbólica del monarca, mediante un instrumento que reforzaba la comunión entre rey y reino materializando el concepto abstracto de monarquía. ${ }^{76}$

73 Estas cláusulas referidas a los fraudes en la predicación aparecen, por ejemplo, en el «recaudo» de García Martínez de Lerma, alcalde mayor de la ciudad de Burgos, dado el 10 de diciembre de 1457 por Gonzalo García de Llerena para la receptoría de las bulas de la Santa Cruzada de las merindades de Rioja y Logroño. AGS, EMR, leg. 8, ff. 933-934.

74 Ver, por ejemplo, la carta de receptoría de la Santa Cruzada del infantazgo de Valladolid dada en favor de Diego Rodríguez de Dueñas, mercader vecino de Valladolid, en Segovia el 30 de mayo de 1457. AGS, EMR, leg. 8, ff. 924-925. O la carta enviada al concejo de Murcia el 4 de febrero de 1458. Benito Ruano 1960: 295-299.

75 «Romançe de la primera bulla que se otorgó al rey, nuestro señor, para la Cruzada» en AMMU, CR, no 798bis, ff. 63v-64v. Traslado romanceado de la bula de Calixto III dada en 1456 en la que se ampliaba la indulgencia a las almas del Purgatorio en AMMU, CR, no 798bis, ff. $64 v-65 r$.

76 Sobre el uso y significado del pendón real en Castilla ver Carrasco Manchado 2006: 524-527.
Más allá de su colaboración en los aspectos ceremoniales, las autoridades concejiles también debían dar todo tipo de facilidades para la predicación de la «Santa Cruzada» en iglesias y plazas, evitando la difusión de otras indulgencias. Asimismo, estaban obligadas a asistir a todos los sermones pronunciados, lo que en última instancia era susceptible de amplificar la difusión del mensaje transmitido por los predicadores en virtud de la capacidad de atracción que los actos en los cuales participaban las elites podían tener sobre sus gobernados. También se encargarían las elites locales de comunicar a la población, mediante pregón dado en plazas y mercados, la situación de seguro y amparo real otorgada por la Corona a los predicadores y receptores para el correcto desempeño de su actividad, y de pregonar igualmente los domingos y fiestas en las iglesias de cada localidad la prohibición - a fin de evitar engaños- de recibir bulas de otras personas, al margen del receptor o de sus delegados. En definitiva, estos pregones en favor de la cruzada - junto a las ceremonias religiosas y sermones - eran susceptibles de mejorar la aceptación por parte de los fieles de los fundamentos políticos y religiosos que respaldaban la campaña de predicación, contribuyendo a su éxito fiscal y al reforzamiento de la imagen del rey. Por ello, habría que considerarlos dentro de las formas de comunicación utilizadas por la monarquía en el marco de las relaciones políticas para difundir rápidamente mediante un formato común noticias cuyo conocimiento se consideraba necesario a fin de crear un estado de opinión favorable entre los súbditos. ${ }^{77}$

Además de los elementos propagandísticos, la logística resultaba igualmente fundamental para el éxito de la predicación, de manera que los poderes locales también se ocuparían de facilitar el alojamiento gratuito de la comitiva en posadas seguras «que non sean mesones» - quizás por su consideración como lugares deshonestos-, buscando en todo momento su integridad personal y la de sus bienes. Los restantes gastos de manutención de predicadores y receptores teóricamente correrían a cargo de cada individuo, aunque las autoridades concejiles estaban obligadas a suministrar las otras cosas "que menester ovieren». Por último, la justicia local sería la encargada de encarcelar y secuestrar los bienes de todos aquellos que importunasen a los predicadores, o incitasen a los fieles a no tomar la bula, para su posterior envío a la corte, donde serían castigados por la justicia regia. Estas medidas podrían constituir un indicio de las posibles resistencias de la población a tomar la bula, argumentadas quizás en la dificultad para aceptar la doctrina de las indulgencias - máxime sobre los fieles difuntos-, o de forma más probable, en la consideración de la "venta» de bulas de cruzada como simonía o mero instrumento de exacción. En este sentido, las fuentes apenas aportan datos sobre el pago de las limosnas por parte de los fieles, aunque parece claro que ya se encontraban operativas prácticas como el empadronamiento de bulas que constatan los límites impuestos a la teórica libertad o "espontaneidad» de los fieles para tomar la bula. ${ }^{78}$

\footnotetext{
77 Nieto Soria 2012b: 77-102.
}

78 Por ejemplo, sabemos que el 30 de marzo de 1460 Enrique IV encomendaba a Cristóbal de Elguera, Juan de Segovia y Juan de Santo Domingo, vecinos de Burgos, el cobro de las cantidades adeudadas a Francisco Martínez de Ávila, morador en Cebreros y recaudador de las bulas de las merindades de Carrión, Saldaña y Aguilar de Campoo con 
EL NEGOCIO FISCAL EN TORNO A LA CRUZADA: PERFIL SOCIO-PROFESIONAL DE LOS RECEPTORES

Más allá de la dimensión política y el carácter religioso asignado a la predicación de la cruzada, las tareas de gestión llevadas a cabo por los receptores nombrados por la monarquía también tenían asociado un marcado componente lucrativo en virtud de la consideración como «negocio» que era susceptible de adoptar la distribución de las indulgencias entre los fieles. Hay que tener en cuenta que la gestión de la bula de cruzada se regía por los mismos parámetros vinculados a la búsqueda del beneficio económico $-y$ también de la inserción en las estructuras de poder, tanto a nivel local como general, a partir del servicio prestado a la Corona- que guiaban la actuación de los grupos financieros en otros campos hacendísticos, como el arrendamiento de tributos regios ordinarios y extraordinarios. ${ }^{79}$ No obstante, resulta complejo dilucidar para esta época el margen de beneficio extraído de la actividad de los receptores ${ }^{80}$, el marco gerencial configurado por estos agentes (formación de sociedades, reparto de beneficios, intervención de agentes delegados o factores...), y los vínculos del negocio establecido en torno a la distribución de las bulas con otras esferas políticas y económicas.
A fin de profundizar en estos aspectos, se propone un acercamiento global a la identidad y perfil socio-profesional de los receptores de la cruzada predicada desde 1457. Para ello se ha elaborado una nómina (ver Tabla 1) a partir de la consulta de las cartas de "recaudo" y otra documentación complementaria, y de los datos incluidos en el cargo o ingreso de los maravedíes de la cruzada recibidos desde mayo de 1461 hasta fines de septiembre de 1462 por el contador mayor Diego Arias Dávila, que gestionó - tal y como veremos - el producto de una parte sustancial de los fondos procedentes de las campañas de predicación. ${ }^{81}$ En total, conocemos la identidad de 28 receptores de la cruzada que desarrollaron su actividad en las diferentes circunscripciones en las que se dividía el reino a efectos de recaudación. Estos distritos se estructuraban a partir de criterios de delimitación política tradicional - merindades en la zona norte de Castilla, condado y señorío de Vizcaya-, y de la división eclesiástica del territorio castellano en arzobispados, obispados y arcedianazgos establecida en el siglo XIII, que en parte también conformaba a mediados del siglo XV la base de la división administrativa del reino a efectos de tributación ordinaria (alcabalas y tercias, moneda forera) y extraordinaria (servicios de Cortes). ${ }^{82}$

TABLA 1

Receptores de la cruzada nombrados por Enrique IV ${ }^{83}$

\begin{tabular}{|c|c|c|c|c|c|}
\hline Partido/circunscripción & Receptor & Vecindad & Oficio/ cargo & $\begin{array}{l}\text { Fecha de } \\
\text { nombramiento }\end{array}$ & $\begin{array}{l}\text { Fecha del } \\
\text { recaudo y } \\
\text { juramento }\end{array}$ \\
\hline 1. Ávila, ob. & Blázquez, Fernán & & Chantre de Ávila & & \\
\hline 2. Badajoz, Coria y Cáceres, ob. & Soria, Diego de & Toledo & & & $1457-6-14$ \\
\hline $\begin{array}{l}\text { 3. Campos con Palencia, merindad, con la } \\
\text { villa de Paredes de Nava }\end{array}$ & $\begin{array}{l}\text { González de Sevilla, } \\
\text { Francisco }\end{array}$ & Palencia & Escribano de cámara del rey & 1457-5-30. Segovia & \\
\hline 4. Cartagena, ob., con el reino de Murcia & Alcalá, Diego de & Uclés & Escribano de cámara del rey & 1458-2-4. Madrid & \\
\hline 5. Castilla Vieja, merindad & González de Cisneros, Alfonso & & [Escribano de cámara del rey] & & \\
\hline 6. Córdoba, ob. & Peñafiel, Juan de & & & & \\
\hline $\begin{array}{l}\text { 7. Cuenca, ciudad y ob., con el infantazgo } \\
\text { de Huete, sin Huete y su arciprestazgo; } \\
\text { lugares del marquesado de Villena en } \\
\text { los ob. de Cuenca y Cartagena }\end{array}$ & González de Nieva, Juan & Santa María de Nieva & Escribano del rey & 1457-5-30. Segovia & \\
\hline 8. Écija, partido de & García de Madrid, Alonso & & & & \\
\hline 9. Guadalajara, arc. & Díaz de Alcocer, Fernando & Alcalá de Henares & Escribano de cámara del rey & & \\
\hline $\begin{array}{l}\text { 10. Huete, ciudad, y las villas y lugares del } \\
\text { partido de la Provincia de Castilla de la } \\
\text { orden de Santiago }\end{array}$ & Fernández de Toledo, Pedro & $\begin{array}{l}\text { [Escribano de cámara } \\
\text { del rey] }\end{array}$ & & 1457-5-30. Segovia & \\
\hline
\end{tabular}

81 Se ha consultado el original de este documento, conservado en AGS, CSR, leg. 97, ff. 56-146, a pesar de que cuenta con un excelente estudio general, en el cual, sin embargo, no se registra la identidad de los agentes fiscales referidos en el documento. Ladero Quesada 2009b: 543-559. Los datos referidos a los receptores y tesoreros de la cruzada se encuentran en AGS, CSR, leg. 97, ff. 77-81.

82 Sobre la división del reino en partidos fiscales ver el trabajo de

Liébana y Pernía, una vez examinadas «las obligaçiones e conoçimientos e padrones e otras escripturas» entregadas por el receptor. AGS, EMR, leg. 6, ff. 12-13.

79 Ver a este respecto Ortego Rico 2015.

80 Ya se ha señalado que, teóricamente, de cada 200 mrs de limosna 50 mrs quedaban en poder del receptor. No obstante, era necesario descontar los derechos del comisario general, de los contadores mayores, y el salario de los predicadores y el restante personal encargado de la recaudación. adero Quesada 2009c: 487-505.

83 Fuentes: AGS, EMR, leg. 8, ff. 920-921, 924-925, 927-930, 933-934, 943-944, 995-996, 1005-1009, 1016-1018, 1021-1024, 10301035, 1038-1041, 1046-1047, 1053-1056 y 1058-1066: AGS, CSR, leg. 97, ff. 77r-v, 78r-v, 79r-v, 80r y 102r; AMMU, CR, no 798bis, ff. 61v-63r. Abreviaturas empleadas: arc. = arcedianazgo; arz. = arzobispado; ob. = obispado. Entre corchetes se incluyen los oficios o cargos no mencionados explícitamente en la documentación referida a la cruzada, pero conocidos a partir de otras fuentes. 


\begin{tabular}{|c|c|c|c|c|c|}
\hline Partido/circunscripción & Receptor & Vecindad & Oficio/ cargo & $\begin{array}{c}\text { Fecha de } \\
\text { nombramiento }\end{array}$ & $\begin{array}{l}\text { Fecha del } \\
\text { recaudo y } \\
\text { juramento }\end{array}$ \\
\hline 11. Jaén, ob. & Sánchez de Córdoba, Sancho & Úbeda & Regidor de Úbeda & 1457-5-30. Segovia & $1457-7-5$ \\
\hline $\begin{array}{l}\text { 12. León y Palencia, ob.; Logroño, Nájera y } \\
\text { Calahorra }\end{array}$ & $\begin{array}{l}\text { González de Madrid, } \\
\text { Francisco }\end{array}$ & & $\begin{array}{l}\text { [Escribano de cámara del } \\
\text { rey] }\end{array}$ & & \\
\hline 13. Madrid, arc., con el Real de Manzanares & $\begin{array}{l}\text { Sánchez de Salamanca, } \\
\text { Benito }\end{array}$ & Madrid & $\begin{array}{l}\text { Escribano de cámara del rey } \\
\text { y su vasallo }\end{array}$ & & $1457-6-20$ \\
\hline $\begin{array}{l}\text { 14. Medina del Campo, Arévalo, Olmedo, } \\
\text { Madrigal, Alaejos, Castrejón, } \\
\text { Valdefuentes y Bobadilla, con sus tierras }\end{array}$ & $\begin{array}{l}\text { Arias, Alfón. Hijo de Juan } \\
\text { Álvarez de Mercado }\end{array}$ & Arévalo & & & $1457-6-14$ \\
\hline 15. Osma, ob. & González Mercadal, Diego & & & & \\
\hline 16. Plasencia, ob.; Talavera, arc. & González de San Martín, Ruy & [Talavera, Toledo] & [Escribano de cámara del rey] & & \\
\hline 17. Rioja y Logroño, merindades & Martínez de Lerma, García & Burgos & Alcalde mayor de Burgos & & $1457-12-10$ \\
\hline $\begin{array}{l}\text { 18. Salamanca, ob. sin Medina, Alaejos, } \\
\text { Castrejón y Bobadilla }\end{array}$ & López de San Miguel, Alfón & Medina del Campo & Vasallo del rey & 1457-12-10. Madrid & $1457-12-10$ \\
\hline $\begin{array}{l}\text { 19. Saldaña, Aguilar de Campoo, Liébana, } \\
\text { Pernía, Carrión y su arc., merindades, } \\
\text { sin Paredes de Nava }\end{array}$ & Martínez de Ávila, Francisco & Cebreros & Escribano del rey & 1457-12-19. Madrid & $1457-12-20$ \\
\hline $\begin{array}{l}\text { 20. Santiago, arz., con los ob. de Tuy, } \\
\text { Orense, Lugo y Mondoñedo; Oviedo, } \\
\text { ob., con San Vicente de la Barquera y su } \\
\text { tierra; Astorga con su tierra y ob. }\end{array}$ & Oviedo, Juan de & Oviedo & $\begin{array}{l}\text { Mayordomo del Principado } \\
\text { de Asturias }\end{array}$ & $\begin{array}{l}\text { 1457-4-9. Santo } \\
\text { Domingo de la Calzada }\end{array}$ & \\
\hline 21. Segovia, ob. & García de la Torre, Pedro & & & & \\
\hline 22. Sevilla, arz. & Sánchez Alemán, Juan & Sevilla & Jurado de Sevilla & & \\
\hline 23. Sigüenza, ob. & Sánchez de Torre, Juan & [Sigüenza] & [Escribano de cámara del rey] & 1457-5-30. Segovia & \\
\hline 24. Toledo, arc. & Cota, Alonso & [Toledo] & Tesorero & & \\
\hline 25. Valladolid, Infantazgo & Rodríguez de Dueñas, Diego & Valladolid & Mercader & 1457-5-30. Segovia & \\
\hline $\begin{array}{l}\text { 26. Vizcaya, condado y señorío, con } \\
\text { las Encartaciones, la Provincia de } \\
\text { Guipúzcoa y la merindad de Allendebro }\end{array}$ & Sánchez de Salinas, Juan & Nájera & & 1457-3-30. Segovia & $1457-7-26$ \\
\hline 27. Zamora y Ciudad Rodrigo, ob. & $\begin{array}{l}\text { Fernández de Zamora, } \\
\text { García }\end{array}$ & & $\begin{array}{l}\text { [Escribano de cámara del } \\
\text { rey] }\end{array}$ & & $1457-10-31$ \\
\hline 28. - & González de Ágreda, Diego & & & & \\
\hline
\end{tabular}

El perfil profesional de un número significativo de estos receptores de la cruzada remite en primer lugar a agentes del entorno regio adscritos a los cuadros burocráticos de la monarquía, muchos de los cuales contaban, además, con experiencia previa en la gestión de capitales financieros y mercantiles. Así, entre los receptores cuyo oficio o actividad profesional al margen de la gestión de la cruzada conocemos aparecen nueve escribanos de cámara del rey, dos escribanos reales, un tesorero y el mayordomo del Principado de Asturias. En este sentido, la nutrida presencia de agentes integrados en los diferentes escalones de la burocracia cortesana, o dedicados a la gestión de rentas de la monarquía, probablemente responde, en primer lugar, a las facilidades que el acceso al entorno regio, o el sostenimiento de relaciones informales con los centros de poder de la corte -fundamentalmente con el polo aglutinado en torno a los contadores mayores, aunque no solo-, habilitaba a la hora de acceder, desde una posición ventajosa, a un oficio como el de receptor de la cruzada otorgado directamente por el monarca. Además, desde el punto de vista de la Real Hacienda, y de los oficiales que la dirigían, la posibilidad de contar con este tipo de operadores facilitaba el control sobre su actividad, y ofrecía garantías de cara al desarrollo exitoso de las campañas de predicación al situar su gestión logística y financiera en manos de personal cualificado con experiencia en tareas administrativas y recaudatorias que requerían, además, de un buen conocimiento del territorio en el cual se desarrollaría su función, y de una red de relaciones formales e informales previamente establecida en muchos casos.

Pasando al análisis de los datos concretos, los escribanos de cámara del rey desempeñaron -como en otros aspectos de la gestión hacendística y fiscal durante esta época ${ }^{84}-$ un papel muy destacado en la recaudación de la cruzada. Los nueve receptores conocidos que desempeñaron este oficio se encuadran dentro de un mismo perfil, en el que la integración en el entorno cortesano des de la década de 1440, por un lado, y la intervención previa o simultánea en labores de recaudación de rentas regias ordinarias y extraordinarias,

84 Los vínculos de los escribanos de cámara con la gestión hacendística y fiscal han sido abordados por Cañas Gálvez 2012: 124-139. Para el ámbito del arzobispado de Toledo y obispado de Sigüenza, las relaciones entre agentes integrados en las estructuras burocráticas de la monarquía (escribanos del rey, escribanos de cámara) y la corte regia y el negocio fiscal ver Ortego Rico 2015: 203-216. 
por otro, eran notas habituales. Así se deduce del análisis de los siguientes perfiles prosopográficos:

- El escribano de cámara Juan Sánchez de Torre, vecino de Sigüenza y receptor de la cruzada en el mismo obispado, figura como fiador por 150.000 mrs anuales de Fernán López de Burgos, vecino de Toledo y recaudadorarrendador mayor durante el cuatrienio 1455-1458 de las alcabalas del arcedianazgo de Calatrava. ${ }^{85}$

- Alfonso González de Cisneros, receptor de la cruzada en la merindad de Castilla la Vieja, venía desempeñando desde al menos 1447 un oficio de escribanía de cámara. Ese mismo año ejerció como recaudador mayor de las 24 monedas de la merindad de Carrión, contando con la fianza de Francisco González de Madrid. ${ }^{86}$ Este último agente se encontraba avecindado en Palencia y ocupaba una escribanía de cámara desde al menos 1442. Su trayectoria como financiero le llevó a intervenir entre 1441 y 1453 en distintos arrendamientos de rentas regias por mayor en su entorno más cercano (merindades de Monzón, Cerrato, Carrión y Campos con Palencia) ${ }^{87}$, y finalmente a ocupar la receptoría de la cruzada de los obispados de León y Palencia, y de Logroño, Nájera y Calahorra.

- Ruy González de San Martín, vecino de San Martín de Valdeiglesias - aunque también figura en algunos momentos como vecino y regidor de Toledo-, ocupaba desde 1446 una escribanía de cámara y venía participando desde al menos la década de 1440 en la gestión "por mayor» de rentas regias ordinarias y extraordinarias - fundamentalmente correspondientes al arcedianazgo de Talavera - junto a su hermano Pedro González de San Martín. ${ }^{88}$ Esta circunstancia explicaría su nombramiento como receptor de la cruzada en el arcedianazgo talaverano y en el vecino obispado de Plasencia, donde la familia tenía asentadas sus bases económicas y políticas. Cabe señalar, como nota complementaria, que Ruy González fue el encargado de recibir la limosna de 200 mrs entregada por la infanta Isabel de Castilla para la cruzada. ${ }^{89}$

- De los restantes escribanos de cámara incluidos en la nómina de receptores únicamente conocemos - a la espera de ampliar su cursus honorum - su intervención en el ámbito de la fiscalidad regia a partir de la gestión de la cruzada. Es el caso de Diego de Alcalá, vecino de Uclés, y receptor de la cruzada en el obispado de Cartagena y reino de Murcia; de Benito Sánchez de Salamanca, receptor en el arcedianazgo de Madrid ${ }^{90}$;

85 La renta también fue avalada por Juan García de Almazán, vecino de Sigüenza, y Juan García de Tordesillas, vecino de Molina de Aragón. AGS, EMR, leg. 4-2, f. 726.

86 Cañas Gálvez 2012: 367.

87 Ibídem: 378.

88 Ibídem: 382-383; Ortego Rico 2015: 149-156.

89 La bula fue expedida el 4 de diciembre de 1458 y está firmada por Alonso de Palencia, "coronista e secretario de latyn» de Enrique IV y diputado por el arzobispo de Sevilla para la cruzada. AGS, PR, leg. 19, doc. 2. Palencia 1999: 538-539.

90 Benito Sánchez de Salamanca era padre de Diego de Aguilar, vecino de Madrid, que en 1485 solicitaba a los Reyes Católicos autorización para cobrar ciertas deudas de las cuales era acreedor su difunto padre. AGS, RGS, abril de 1485, f. 59 de Pedro Fernández de Toledo, receptor de la ciudad de Huete y la Provincia de Castilla de la orden de Santiago ${ }^{91}$; de Francisco González de Sevilla, vecino de Palencia y receptor de la cruzada en la merindad de Campos con Palencia, con la villa de Paredes de Nava92; de García Fernández de Zamora, receptor de la cruzada en los obispados de Zamora y Ciudad Rodrigo ${ }^{93}$; y del judeoconverso Fernando Díaz de Alcocer, vecino de Alcalá de Henares y receptor de la cruzada en el arcedianazgo de Guadalajara, perfectamente integrado desde fines del reinado de Juan II en los cuadros burocráticos de la monarquía ${ }^{94}$, de los cuales también formaría parte en el futuro su hijo Juan Díaz de Alcocer, importante consejero de los Reyes Católicos. ${ }^{95}$

Además de los profesionales de la escritura adscritos a la burocracia cortesana - escribanos de cámara, y escribanos del rey ${ }^{96}$-, los oficios de tesorería y de centralización de caudales, bajo las diversas formas y nomenclaturas que podían adoptar, fueron igualmente utilizados en algunos casos como plataforma de acceso a las receptorías de la cruzada. Por ejemplo, al frente de la receptoría del arcedianazgo de Toledo se situó el jurado, fiel ejecutor toledano y tesorero Alonso Cota, destacado operador judeoconverso que identificamos con el personaje homónimo cuya casa había sido blanco de la ira popular durante la revuelta anti-conversa de 1449 al ser considerado instigador del empréstito solicitado por don Álvaro de Luna que dio origen al conflicto. ${ }^{97}$ En el caso de Alonso Cota, la integración política y la red de relaciones sostenidas en Toledo probablemente actuaron como condicionantes favorables para su designación como tesorero de la cruzada en este espacio, amplificada gracias a dos circunstancias complementarias. Por un lado, la convergencia de intereses con el staff cortesano en virtud de los vínculos familiares y en términos de identidad socio-religiosa que sostenía con el contador mayor Diego Arias Dávila, cuyo hijo Pedro Arias Dávila contrajo matrimonio - según apunta F. Cantera-, con María Ortiz, hija de Alonso Cota. ${ }^{98}$ Por otro, el control ejercido por Cota sobre la recaudación de las alcabalas de Toledo durante el cuatrienio 1459-1462 a través de su criado

91 En septiembre de 1469 Gonzalo García de Llerena renunciaba 10.000 mrs a favor de Francisco Fernández de Sevilla, contador del rey, y 4.000 mrs a favor de Pedro Fernández de Toledo, escribano de cámara de Enrique IV. Cañas Gálvez 2012: 342. No obstante, desconocemos si ya en 1457-1462 Fernández de Toledo ejercía como escribano de cámara.

92 Quizás pueda ser identificado con el Francisco González de Sevilla, escribano de cámara, referido en Cañas Gálvez 2012: 386-387.

93 En diciembre de 1444 era escribano del número de Zamora y desde al menos 1448 ocupaba una escribanía de cámara. Ibídem: 332.

94 Fue escribano de cámara y guarda - esto último desde 1447- de Juan II. Tras su muerte el infante Alfonso, intitulándose rey, ordenaba el 12 de febrero de 1468 a sus contadores mayores que los 18.000 mrs que tenía «de por vida» con el oficio de la escribanía de cámara pasasen, igualmente de por vida, a su hijo Sancho Díaz de Alcocer. AGS, EMR, leg. 15, f. 414.

95 Cañas Gálvez 2012: 296; Rábade Obradó 1990: 261-263.

96 Juan González de Nieva, escribano del rey, ejerció como receptor de la cruzada en la ciudad y obispado de Cuenca y el marquesado de Villena, y Francisco Martínez de Ávila, igualmente escribano del rey, fue nombrado receptor de la cruzada en las merindades de Saldaña, Aguilar de Campoo, Liébana, Pernía y Carrión.

97 Sobre los Cota toledanos ver Cantera Burgos 1969 y la información y bibliografía recogida en Ortego Rico 2015: 181-192.

98 Cantera Burgos 1969: 11-12. 
Juan García de Palencia99, que le permitió dirigir a lo largo de estos años la gestión de la fiscalidad regia en la Ciudad Imperial en unos términos casi «monopolísticos».

En otras ocasiones, las funciones de tesorería ejercidas en un espacio concreto facilitaron el acceso al oficio de receptor de la cruzada en unas condiciones ventajosas que implicaban, además, una extensión de la actividad a entornos próximos, y con ello una ampliación de las bases del negocio fiscal. Es el caso del mayordomo y recaudador mayor del Principado de Asturias Juan de Oviedo, vecino de Oviedo y entre 1449 y 1465 figura de confianza de Enrique IV para la gestión hacendística de este espacio situado bajo el control directo del monarca a pesar de su acceso al trono ${ }^{100}$-, nombrado receptor de la cruzada en un amplísimo territorio que englobaba el reino de Galicia (arzobispado de Santiago con los obispados de Tuy, Orense, Lugo y Mondoñedo), el obispado de Oviedo con San Vicente de la Barquera y el obispado de Astorga. ${ }^{101}$

Aunque en una escala menor, esta misma diversificación en el desempeño de oficios hacendísticos se constata al profundizar en los perfiles profesionales de otros agentes que, antes de su nombramiento como receptores, también habían llevado a cabo funciones recaudatorias en las mismas áreas donde posteriormente desarrollarían su actividad al frente de la administración de la bula de cruzada. Es el caso de Alfón López de San Miguel, vecino de Medina del Campo, vasallo del rey, y receptor de la cruzada en el obispado de Salamanca — sin Medina, Alaejos, Castrejón y Bobadilla-, cuya intervención en la recaudación de alcabalas y tercias en el obispado salmantino - particularmente en Ledesmaestá constatada en $1456 .{ }^{102}$ También de Juan Sánchez de Salinas, vecino de Nájera, y receptor de la cruzada en el condado y señorío de Vizcaya, con las Encartaciones, la Provincia de Guipúzcoa y la merindad de Allendebro, cuyos servicios como mayordomo del marqués de Santillana son conocidos. ${ }^{103}$

Por otro lado, también encontramos una abundante representación de individuos adscritos a las oligarquías urbanas -así consideradas en función del desempeño de cargos dotados de responsabilidad política (escribanos del concejo, jurados, regidores, alcaldes) - al frente de

99 Juan García de Palencia fue nombrado arrendador y recaudador mayor con la fianza de su patrono Alonso Cota, y de Sancho Cota, hermano de este último AGS, EMR, leg. 5-2, ff. 496-502.

100 Buena parte de las rentas cobradas en el Principado disfrutado por Enrique IV pasaron a ingresar en la «cámara real». Ladero Quesada 2009b: 547-550.

101 Sobre Juan de Oviedo ver González González 2015: 291-323.

102 El 12 de enero de 1456 Diego Álvarez de Córdoba, Pedro González del Castillo y Juan de Cuéllar, arrendadores y recaudadores mayores por tercios de las alcabalas y tercias del obispado de Salamanca de 1456, comunicaban al concejo de Ledesma que Alfón López de San Miguel, vecino de Medina del Campo, sería el encargado de recaudar las rentas de la villa y su tierra en virtud de la postura que había presentado sobre las mismas. Martín Expósito y Monsalvo Antón 1986: 168-169.

103 En septiembre de 1465 Juan Sánchez de Salinas era mencionado como mayordomo del marqués de Santillana en la sentencia arbitral en la que se fijaban los límites territoriales de Chinchetru y de otras aldeas vecinas, con la aldea despoblada de Elguea. Goicolea Julián 2002: 193. Desconocemos si se trata del mismo Juan Sánchez de Salinas que en 1436 figura como mayordomo de Fernán Pérez de Ayala en el testamento de este último, aunque la distancia temporal parece indicar que nos encontramos ante dos personajes diferentes. García de Cortázar y Ruiz de Aguirre 1979: 141. oficios de receptoría de cruzada en aquellos distritos donde desarrollaban su función política. Esta circunstancia siempre podría contribuir a consolidar una posición de fortaleza en el escenario local, en virtud del especial servicio prestado a la Corona, de los vínculos habilitados más allá del entorno más inmediato gracias a las relaciones estrechadas con la corte y la administración hacendística de la monarquía, y de las ganancias derivadas de la organización de las campañas de predicación. ${ }^{104}$ En este grupo, además del jurado toledano Alonso Cota, o de Ruy González de San Martín - regidor de Toledo desde al menos $1447^{105}$ - , habría que incluir a agentes como el alcalde mayor de Burgos García Martínez de Lerma, receptor de la cruzada en las merindades de Rioja y Logroño, y figura destacada de la oligarquía burgalesa ${ }^{106}$; el jurado sevillano Juan Sánchez Alemán, receptor del arzobispado de Sevilla, y miembro de una familia integrada en la élite del común hispalense con amplia representación en el ámbito de las finanzas concejiles y en la actividad mercantil durante la segunda mitad del siglo $\mathrm{XV}^{107}$; o el regidor de Úbeda Sancho Sánchez de Córdoba, receptor de la cruzada en el obispado de Jaén, que en septiembre de 1459 es mencionado junto a Diego Ávila, vecino de Baeza, como recaudador del «pedido» y «monedas» del obispado de Jaén cobrado dicho año. ${ }^{108}$

A la nómina de agentes adscritos a las oligarquías urbanas también podrían incorporarse Alonso García de Madrid, receptor de la cruzada en el partido de Écija, y quizás Pedro García de la Torre, receptor de la cruzada en el obispado de Segovia. En el primer caso, aunque las fuentes consultadas no mencionan la vecindad de Alonso García de Madrid, podemos identificarlo con el jurado de Écija homónimo, en cuyas casas - sitas en la collación de San Juan de Écijapernoctó el contador mayor Diego Arias Dávila el 10 de febrero de 1464 durante la estancia de la corte enriqueña en la ciudad. ${ }^{109} \mathrm{~A}$ este elemento, que resaltaría la especial

104 Sin embargo, la presencia de miembros de las elites clericales entre los receptores se limita únicamente al chantre de Ávila Fernán Blázquez, receptor del obispado abulense, quizás porque -a pesar de su marcado componente religioso- la Corona trató de evitar interferencias eclesiásticas en la gestión de la cruzada.

105 Ortego Rico 2015: 153.

106 Sobre esta familia ver Guerrero Navarrete 1986: 164-166. García Martínez de Lerma obtuvo el oficio tras la renuncia realizada por su padre Sancho Martínez de Lerma en 1450. Ibídem 2013: 82.

107 La intervención del jurado Juan Sánchez Alemán en la fiscalidad concejil sevillana está acreditada. El 9 de octubre de 1458 se menciona su actividad como fiel del vino de Sevilla, junto al veinticuatro Pedro de León. Kirschberg Schenck 2012: 71. Por su parte, en 1475 Tomás Sánchez de Jaén y Alemán Pocasangre, este último probablemente familiar de Juan Sánchez Alemán, arrendaban por diez años el oficio de mayordomía del concejo de Sevilla. El mismo Alemán Pocasangre fue recaudador del partido de la madera de Sevilla en 1472 y tesorero de la Hermandad de la provincia de Sevilla en 1478. Collantes de Terán Sánchez 2000: 19 y 22-23; Triano Milán 2015: 71-72. Por su parte, Diego Sánchez Alemán, figura como cambiador de Sevilla. Otte 1996: 169.

108 Porras Arboledas 2006: 328.

109 El testimonio está sacado del acta de la licitación presentada en Écija en la noche del 10 de febrero de 1464 por Jerónimo Verdugo, criado de Sancho Cota, para el arrendamiento de las alcabalas de la ciudad de Toledo del bienio 1464-1465. Ortego Rico 2015: 188-189. Nos parece más correcta la identificación del receptor Alonso García de Madrid con el jurado homónimo de Écija, en virtud del avecindamiento en el área de implantación donde llevaría a cabo las tareas recaudatorias, que con el agente fiscal del mismo nombre, vecino de Madrid, que venía interviniendo en el arrendamiento de rentas de la monarquía desde la 
proximidad y vinculación entre ambos personajes - cuyos orígenes judeoconversos eran, además, notorios- ${ }^{110}$ habría que añadir de nuevo la experiencia previa alcanzada por Alonso García de Madrid en el marco del negocio fiscal como arrendador y recaudador mayor entre 1455 y 1457 de la mitad de los diezmos de la mar y alfolíes de Galicia. ${ }^{111}$ En el caso de Pedro García de la Torre, receptor en el obispado de Segovia, aunque es segura su identificación con el personaje homónimo que, como escribano del número del concejo segoviano, levantó el acta que recoge la ceremonia de proclamación de Isabel I como reina el 13 de diciembre de $1474^{112}$, desconocemos si a la altura de 1457 ya desempeñaba algún oficio en el marco de la política urbana.

Finalmente, las menciones a receptores vinculados estrictamente al ámbito mercantil son escasas, y se limitan únicamente a Diego Rodríguez de Dueñas, mercader vecino de Valladolid y receptor de la cruzada en el infantazgo de Valladolid, acaso familiar de Alfonso Rodríguez de Dueñas y de su hijo Luis Rodríguez de Dueñas, adscritos ambos a los cuadros de la burocracia cortesana durante el reinado de Juan II13; y quizás a Diego de Soria, vecino de Toledo y receptor de la cruzada en los obispados de Badajoz, Coria y Cáceres. En este último caso existen dudas sobre su posible filiación con el mercader burgalés homónimo nombrado por los Reyes Católicos en marzo de 1480 como receptor y depositario de las bulas de la "santa indulgencia de Canaria», junto al mercader genovés residente en Sevilla Francisco Pinelo ${ }^{114}$; aunque lo cierto es que el desempeño de un oficio semejante podría constituir un indicio de su identificación como la misma persona.

En resumen, a pesar de las carencias documentales y la dificultad para rastrear las carreras y perfiles socioprofesionales de la totalidad de los receptores de la cruzada, es posible ofrecer un conjunto de rasgos generales. Así, al menos un $46 \%$ de estos agentes se encontraba adscrito a los círculos de la burocracia cortesana a través del desempeño de escribanías de cámara (32\%), escribanías reales (7\%) y oficios de tesorería (7\%). La importancia cuantitativa de la vinculación de los receptores de cruzada con el ámbito cortesano es igualmente extensible a la intervención previa de estos agentes en actividades de índole hacendística o financiera - que afecta al menos a un $36 \%$ de los receptoresy a la adscripción a los cuadros dirigentes urbanos, de los cuales procedían al menos un $25 \%$ de los operadores

década de 1440, aunque no podemos descartar ninguna hipótesis. Así, un Alonso García de Madrid, vecino de Madrid y escribano de cámara del rey, fue obligado como fiador en cuantía de 50.000 mrs por Fernán Alonso de Sevilla, escribano de cámara del rey y vecino de Toledo, para el arrendamiento de las alcabalas y tercias del arcedianazgo de Toledo del bienio 1444-1445. AGS, EMR, leg. 2, ff. 236r-237. Por otro lado, Alonso García de Madrid, guarda del rey, y Alonso de Madrid, criado de Alonso González de Herrera - ambos vecinos de Madrid-, arrendaron «por mitad» las tercias del arcedianazgo de Madrid durante el bienio 14441445. AGS, EMR, leg. 2, f. 238r.

110 Un Alonso García de Madrid, marido de Leonor García - condenada por judaizante-figura como escribano público de Écija. Gil 2003: 379.

111 En este caso, es mencionado explícitamente como vecino de Écija. La otra mitad de la renta quedó en manos de Juan García de Villadiego, vecino de Segovia. Rubio Martínez 2010: 114-115.

112 Grau 1949: 20-39. Sobre la familia segoviana de la Torre ver Asenjo González 1986: 405.

113 Cañas Gálvez 2012: 430.

114 Rumeu de Armas 1969: 209-212. conocidos. De este modo, nos encontramos ante un grupo especial de servidores de la monarquía, a caballo entre los tres ámbitos delimitados - burocracia regia, ámbito financiero y poder concejil-, cuya proyección socio-política a partir del desempeño de receptorías de cruzada pudo verse amplificada.

TABLA 2.

Adscripción socio-profesional de los receptores de cruzada en tiempos de Enrique IV

\begin{tabular}{|l|r|r|}
\hline \multicolumn{1}{|c|}{ Categoría } & \multicolumn{1}{|c|}{ No } & \multicolumn{1}{c|}{ \% } \\
\hline Escribanos de cámara & 9 & 32 \\
\hline Escribanos del rey & 2 & 7 \\
\hline Tesoreros & 10 & 36 \\
\hline $\begin{array}{l}\text { Receptores de la cruzada que desempeñaron algún } \\
\text { oficio hacendístico (tesorero, mayordomo, recaudador, } \\
\text { arrendador...), o intervinieron en el negocio fiscal }\end{array}$ & 7 & 25 \\
\hline Receptores adscritos a la oligarquía política concejil & 2 & 7 \\
\hline
\end{tabular}

Menos datos tenemos, por el contrario, sobre los aspectos referidos al personal que, por delegación de los receptores, tomó parte en las tareas de gestión de la cruzada a lo largo de estos años. Las relaciones de entrega de cartas de bula que conservamos únicamente refieren la intervención de diversos agentes secundarios que, previo poder, en ocasiones se encargaron de recibir en nombre de los receptores las remesas de bulas de los delegados de la monarquía. La nómina de apoderados confeccionada (Tabla 3) incluye fundamentalmente dos tipologías de agentes. Por un lado encontramos criados de los receptores, cuyas funciones de representación acaso resultasen equivalentes a las desarrolladas por los factores que trabajaban para las compañías comerciales y las sociedades financieras dedicadas al arrendamiento de rentas regias $^{115}$, aunque adaptadas a las particulares circunstancias asociadas a la gestión de la cruzada. Por otro, aparecen agentes vinculados al entorno familiar de los receptores (hijos, cuñados, yernos), que probablemente iniciaban su aprendizaje ycursus honorum en este tipo de actividades, lo que vendría a sancionar, por otra parte, el marcado componente familiar asociado a este tipo de empresa.

Asimismo, la delegación en operadores secundarios de las labores organizativas de las campañas de predicación en las circunscripciones asignadas a cada receptor, y de las tareas asociadas a la colecta y pagaduría - probablemente a cambio de un salario-, debió ser una práctica habitual, si tenemos en cuenta el grado de diversificación alcanzado por las actividades desarrolladas por muchos de los receptores de la cruzada. De ello da fe, por ejemplo, el poder entregado en Uclés el 8 de marzo de 1458 por Diego de Alcalá, receptor de la cruzada en el obispado de Cartagena y reino de Murcia, a Fernando de Guadalajara, vecino de Uclés, para que, en su nombre, pudiera recaudar y recibir cualesquier maravedíes procedentes de la toma de bulas de cruzada en dicha circunscripción, y realizar las diligencias oportunas (prendas, requerimientos, emplazamientos, solicitudes de venta de bienes...) para cobrar las deudas asociadas a este concepto. ${ }^{116}$

115 Caunedo del Potro 1998: 97-11; Ortego Rico 2015: 41-43.

116 AMMU, CR, no 798 bis, f. 63r-v. 
TABLA 3

Apoderados para la recepción de bulas en nombre de los receptores de la cruzada cuyas relaciones de entrega se conocen

\begin{tabular}{|c|c|c|}
\hline Receptor de la cruzada & Apoderado/ representante para la recepción de las bulas & $\begin{array}{l}\text { Fecha de la actividad como } \\
\text { receptor de bulas }{ }^{117}\end{array}$ \\
\hline Alfón Arias ${ }^{118}$ & Fernando de Villarreal, criado de García de Alcocer & 1457-1-7 [fecha del poder] \\
\hline \multirow{3}{*}{ García Martínez de Lerma ${ }^{119}$} & Juan de Valladolid, criado de García Martínez de Lerma & $1457-6-25$ a $1461-12-2$ \\
\hline & Pedro García de Mazuelo, mercader vecino de Burgos & $1458-10-19 *$ \\
\hline & Juan de Madrid, «facedor» de García Martínez de Lerma & $1462-1-18$ a $1462-3-5$ \\
\hline \multirow{3}{*}{ Francisco González de Madrid ${ }^{120}$} & Pedro de Huete, criado de Francisco González de Madrid & $1457-7-15$ a $1458-6-3^{121}$ \\
\hline & Diego González de Madrid, hermano de Francisco González de Madrid & $1457-7-25^{*}$ \\
\hline & Luis de Sahagún, criado de Francisco González de Madrid & $1459-7-6^{*}$ \\
\hline Francisco Martínez de Cebreros ${ }^{122}$ & Juan Martínez, yerno de Francisco Martínez, vecino de Cebreros & $1458-2-4$ a $1458-2-9$ \\
\hline \multirow{3}{*}{ Diego González de Ágreda ${ }^{123}$} & Fernando, hijo de Diego González de Ágreda & $1457-6-25$ a $1457-6-28$ \\
\hline & Marcos Garcés & $1457-12-10$ a $1462-4-10$ \\
\hline & Juan de Ágreda, hijo de Diego González de Ágreda & $1460-5-30$ a $1462-3-10$ \\
\hline \multirow{4}{*}{ Juan Sánchez de Salinas ${ }^{124}$} & Lope Gutiérrez & $1457-10-18$ a $1457-10-28$ \\
\hline & Pedro de Bilbao, escudero de Juan Sánchez de Salinas & $1458-3-9$ a $1458-3-16$ \\
\hline & Juan Gallo, criado de Juan Sánchez de Salinas & $1459-5-11$ a $1459-5-21$ \\
\hline & Pedro González, yerno de Juan Sánchez de Salinas & $1459-10-17$ a $1459-10-27$ \\
\hline Pedro Fernández de Toledo ${ }^{125}$ & Gonzalo de Bazán, hijo de Pedro Fernández de Toledo & $1457-9-29$ a $1461-7-29$ \\
\hline \multirow{3}{*}{ Ruy González de San Martín ${ }^{126}$} & Fernando de Gálvez, criado de Ruy González de San Martín & $1457-9-28$ a $1461-3-10$ \\
\hline & Rodrigo de San Martín, hijo de Ruy González de San Martín & $1458-4-13^{*}$ \\
\hline & Diego de Calderón, sobrino de Ruy González de San Martín & $1459-8-31^{*}$ \\
\hline Fernando Díaz de Alcocer ${ }^{127}$ & Sancho de Alcocer, hijo de Fernando Díaz de Alcocer & $1457-7-20$ a $1458-6-29$ \\
\hline \multirow{4}{*}{ Juan González de Nieva ${ }^{128}$} & Cristóbal de Medina & $1457-12-10$ a $1462-6-21$ \\
\hline & Juan González de Aranda, cuñado de Juan González de Nieva & $1461-3-17^{*}$ \\
\hline & Alfón López, trapero vecino de Segovia & $1461-12-22^{*}$ \\
\hline & Pedro de Valdeolivas Sentado & $1462-3-22^{*}$ \\
\hline Diego de Soria ${ }^{129}$ & Lope de Villarreal $^{130}$ & $1457-6-14$ [fecha del poder $]^{131}$ \\
\hline
\end{tabular}

\section{EL RENDIMIENTO ECONÓMICO DE LA CRUZADA}

La ausencia de registros contables completos impide realizar una cuantificación exacta de los ingresos obtenidos

117 Entre las cuales está constatada la intervención de un apoderado en la recepción de bulas. Con un asterisco $(*)$ se indica aquellos casos en los cuales solo se observa una única intervención del agente en la recepción de bulas. Igualmente, se especifica entre corchetes [], la fecha del poder dado por los receptores a los agentes que recibirían en su nombre las bulas, cuando se conoce.

118 El 7 de enero de 1457 Alfón Arias otorgó poder a Fernando de Villarreal, criado de García de Alcocer, para recibir cualesquier cartas de bula y hacer cargo de ellas. AGS, EMR, leg. 8, ff. 922-923.

119 AGS, EMR, leg. 8, ff. 935-940 y 1052

120 AGS, EMR, leg. 8, ff. 999-1002.

121 En nota al margen del asiento correspondiente a la entrega de 1.006 cartas de bula realizada en Medina del Campo el 11 de enero de 1459 se señala lo siguiente: «ojo. Revocó el poder que dio a Pedro de Huepte».

122 AGS, EMR, leg. 8, ff. 1010-1011.

123 AGS, EMR, leg. 8, ff. 1016-1018.

124 AGS, EMR, leg. 8, ff. 1025-1027.

125 AGS, EMR, leg. 8, ff. 1036-1037.

126 AGS, EMR, leg. 8, ff. 1038-1039.

127 AGS, EMR, leg. 8, ff. 1042-1043.

128 AGS, EMR, leg. 8, ff. 1048-1051.

129 AGS, EMR, leg. 8, f. 1057.

130 Mencionado también como Lope de Ciudad.

131 El 14 de junio de 1457 ante Gonzalo García de Llerena, escribano de cámara del rey, dio poder Diego de Soria a Lope de Villarreal «para reçebir qualequier cartas de bullas para los obispados de Badajoz e Coria e Cáçeres, e para fazer cargo d'ellas en los libros del rey». Testigos: el tesorero Alonso Cota, Gómez González de la Hoz y Gutierre de Toledo. de la venta de indulgencias, de forma que para aproximarse a la cuestión es necesario recurrir a los testimonios cronísticos. Alonso de Palencia cifra en 800.000 ducados el total ingresado en las arcas regias en concepto de cruzada a lo largo de estos años ${ }^{132}$, mientras que los datos de la Crónica anónima y los aportados por Diego de Valera establecen en 100.000 .000 mrs el rendimiento fiscal de las campañas de predicación, descontados los gastos de tesoreros y receptores. ${ }^{133}$ Esta última cantidad quizás no sea exagerada, a tenor de los registros de entrega de bulas firmados por los receptores/ tesoreros - los primeros sobre esta fuente de renta que se han conservado para Castilla-, en los cuales se hizo constar la siguiente información: día y lugar de recepción de las cartas de bula, agente al cual le eran entregadas (el propio tesorero/ receptor o algún apoderado), número total de bulas recibidas, nombre del delegado del arzobispo de Sevilla que firma las bulas, y testigos presentados para dar fe de la entrega.

Los datos procedentes de los registros conservados -que se refieren únicamente a 10 circunscripciones de las 28 conocidas $^{134}$ - permiten cuantificar el rendimiento teórico obtenido por la Real Hacienda en estos territorios en

132 Palencia 1973: I, 93. En otra parte de la crónica se establece el rendimiento en 1.000.000 ducados. Ibídem: I, 66 .

133 Sánchez Parra 1991: 66. Valera 1941: 41.

134 El registro de las cartas de bula dadas a Diego de Soria, receptor de los obispados de Badajoz, Coria y Cáceres está incompleto, y no se incluye en los datos generales ofrecidos, a fin de no distorsionarlos. Hasta el 17 de diciembre de 1458 había recibido 6.418 cartas de bula. AGS, EMR, leg. 8, f. 1057. 
31.932.150 mrs, correspondiente a 212.881 cartas de bula por cuya entrega se habrían recaudado un total de 42.576 .200 mrs sin descontar el $25 \%$ correspondiente a los gastos logísticos. ${ }^{135}$ Sorprende el elevado número de bulas asignadas para su distribución en circunscripciones de tamaño reducido como las merindades de Rioja y Logroño, o la que englobaba a los territorios vascongados - condado y señorío de Vizcaya con las Encartaciones, la provincia de Guipúzcoa y la merindad de Allendebro-, frente al menor número de indulgencias entregadas a los receptores de demarcaciones más extensas, por ejemplo la ciudad y obispado de Cuenca con el infantazgo de Huete y los lugares del marquesado de Villena en los obispados de Cuenca y Cartagena. No obstante, sabemos de la existencia de trasvases o "préstamos» de bulas entre los receptores de unas y otras circunscripciones que habría que relacionar, entre otras motivaciones, con los niveles de éxito en la colocación de bulas observados en cada territorio. ${ }^{136}$

Según los registros conservados, la entrega de cartas de bula a los receptores se mantuvo de forma intermitente entre junio de 1457 y junio de $1462 .{ }^{140}$ El período $1457-1459$ concentró el $90 \%$ de las entregas conocidas - solo en 1458 se dieron 96.737 cartas de bula para su distribución en las 10 circunscripciones para las cuales contamos con datos, correspondientes al 46 $\%$ del total conocido-, con picos importantes en octubre y noviembre de 1457, febrero, marzo, mayo y junio de 1458 , y mayo y octubre de 1459. Durante el trienio $1460-1462$ las remesas entregadas cayeron notablemente (4\% del total en $1460,6 \%$ en 1461 y $1 \%$ en 1462), quizás porque los propios receptores todavía contaban con un stock de bulas suficiente, procedente de entregas previas, o porque en aquel momento ya existían dificultades para seguir colocando cartas de bula en el «mercado de limosnas», quizás como consecuencia del propio agotamiento económico de los fieles, o de su falta de motivación para seguir aportando recursos a una empresa, como la granadina, que apenas había arrojado resultados en términos de ganancia territorial. Asimismo, un elevado porcentaje de las bulas registradas - hasta el $60 \%$ - fue distribuido a los receptores durante los meses de mayo-junio

TABLA 4

№ de bulas recibidas en cada circunscripción, ingresos derivados de su venta, y gasto conocido ${ }^{137}$

\begin{tabular}{|c|c|c|c|c|}
\hline Partido/circunscripción & № bulas & $\begin{array}{l}\text { Total } \\
\text { Hacienda } \\
\text { Real }^{138}\end{array}$ & $\begin{array}{l}\text { Gasto } \\
\text { conocido }\end{array}$ & $\begin{array}{l}\text { Total } \\
\text { recaudado }^{139}\end{array}$ \\
\hline $\begin{array}{l}\text { Medina del Campo, Arévalo, Olmedo, Madrigal, Alaejos, Castrejón, } \\
\text { Valdefuentes y Bobadilla con sus tierras }\end{array}$ & 6.508 & 976.200 & - & 1.301 .600 \\
\hline Valladolid, Infantazgo & - & - & 1.296 .759 & - \\
\hline Rioja y Logroño, merindades & 76.079 & 11.411 .850 & 8.477 .847 & 15.215 .800 \\
\hline Campos con Palencia, merindad, con la villa de Paredes de Nava & 24.205 & 3.630 .750 & - & 4.841 .000 \\
\hline $\begin{array}{l}\text { Saldaña, Aguilar de Campoo, Liébana, Pernía, Carrión y su } \\
\text { arcedianazgo, merindades, sin Paredes de Nava }\end{array}$ & 13.516 & 2.027 .400 & 2.037 .455 & 2.703 .200 \\
\hline Receptoría de Diego González de Ágreda, de partidos desconocidos & 10.139 & 1.520 .850 & 1.518 .021 & 2.027 .800 \\
\hline $\begin{array}{l}\text { Vizcaya, condado y señorío, con las Encartaciones, la Provincia de } \\
\text { Guipúzcoa y la merindad de Allendebro }\end{array}$ & 48.259 & 7.238 .850 & 5.248 .041 & 9.651 .800 \\
\hline $\begin{array}{l}\text { Huete, ciudad, y las villas y lugares del parrido de la Provincia de } \\
\text { Castilla de la orden de Santiago }\end{array}$ & 5.618 & 842.700 & - & 1.123 .600 \\
\hline Plasencia, obispado; Talavera, arcedianazgo & 6.381 & 957.150 & & 1.276 .200 \\
\hline Guadalajara, arcedianazgo & 4.941 & 741.150 & 740.693 & 988.200 \\
\hline $\begin{array}{l}\text { Cuenca, ciudad y obispado, con el infantazgo de Huete, sin Huete } \\
\text { y su arciprestazgo; lugares del marquesado de Villena en los } \\
\text { obispados de Cuenca y Cartagena }\end{array}$ & 17.235 & 2.585 .250 & - & 3.447 .000 \\
\hline Cartagena, obispado, con el reino de Murcia & - & - & 1.198 .578 & - \\
\hline TOTAL CONOCIDO & 212.881 & 31.932 .150 & 20.517.394 & 42.576 .200 \\
\hline
\end{tabular}

( 58.579 bulas, correspondientes al $28 \%$ ) y octubre-noviembre (67.113 bulas, correspondientes al $32 \%$ ), circunstancia que hay que poner en relación con el destacado papel que las

135 Ladero habla de un rendimiento de más 35.000 .000 mrs referido tan solo a los partidos cuyas cuentas se conocen. Ladero Quesada 2009a: 230.

136 Por ejemplo, a Gonzalo Martínez de Lerma le fueron cargadas 1.600 cartas de bula, «que le prestó lohan Sánchez de Salinillas, reçebtor de çiertas merindades, las quales se descargan al dicho lohan Sánchez». AGS, EMR, leg. 8, ff. 935-940 y 1052.

137 Fuentes: AGS, EMR, leg. 8, ff. 922-923, 935-942, 999-1002, 1010-1013, 1016-1020, 1025-1029, 1036-1039, 1042-1045, 1048-1054 y $1063-1064$

138 A $150 \mathrm{mrs} /$ bula.

139 A $200 \mathrm{mrs} /$ bula. dos ferias celebradas en Medina del Campo (mayo y octubre) tuvieron como punto de centralización de la entrega de bulas, aprovechando la concentración de pagos en esta plaza. Entre estos desembolsos, encontramos muchos de los referidos a

140 La última remesa de bulas documentada se entregó en Medina del Campo el 21 de junio de 1462 a Juan González de Nieva, receptor de la cruzada en la ciudad y obispado de Cuenca, con el infantazgo de Huete, sin Huete y su arciprestazgo, y con los lugares del marquesado de Villena en los obispados de Cuenca y Cartagena. AGS, EMR, leg. 8, ff. 1048-1051. 
las cantidades recaudadas en concepto de cruzada por los mismos receptores a los que se entregarían - aprovechando su presencia en Medina- nuevas remesas de bulas. Además de Medina del Campo, también Madrid y Segovia, como principales centros de aposentamiento de la corte enriqueña a lo largo de este período, fueron lugares habituales para la entrega de cartas de bula a los receptores. ${ }^{141}$

TABLA 5

Distribución por años de las cartas de bulas recibidas por los receptores de la cruzada cuyas registros de entrega se conocen $(1457-1462)^{142}$

\begin{tabular}{|c|c|c|}
\hline Año & No cartas de bula & \% \\
\hline 1457 & 37.813 & 18 \\
\hline 1458 & 96.737 & 46 \\
\hline 1459 & 54.152 & 26 \\
\hline 1460 & 7.488 & 4 \\
\hline 1461 & 13.162 & 6 \\
\hline 1462 & 1.929 & 1 \\
\hline TOTAL & $\mathbf{2 1 1 . 2 8 1}{ }^{143}$ & $\mathbf{1 0 0}$ \\
\hline
\end{tabular}

Gráfico 1

Evolución cronológica de la recepción de cartas de bula por parte de los receptores de la cruzada cuyos registros de entrega se conocen (1457-1462) ${ }^{144}$

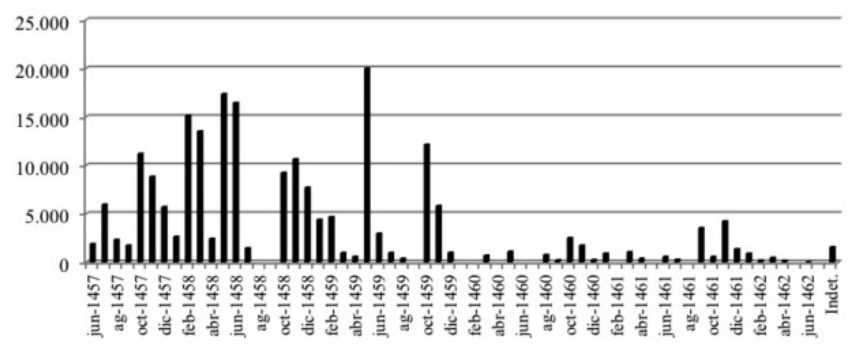

141 Sobre las estancias de la corte enriqueña en Madrid y Segovia, y sus implicaciones políticas, ver Rábade Obradó 2009: 8; Foronda 2003: 521-542.

142 Fuentes: AGS, EMR, leg. 8, ff. 922-923, 935-942, 999-1002, 1010-1013, 1016-1020, 1025-1029, 1036-1039, 1042-1045, 1048-1054 y 1063-1064. El gráfico recoge los datos conjuntos de las siguientes circunscripciones: Medina del Campo, Arévalo, Olmedo, Madrigal, Alaejos, Castrejón, Valdefuentes y Bobadilla con sus tierras; merindades de Rioja y Logroño; merindad de Campos con Palencia, y Paredes de Nava; merindades de Saldaña, Aguilar de Campoo, Liébana, Pernía, Carrión y su arcedianazgo, sin Paredes de Nava; receptoría de Diego González de Ágreda; Vizcaya y provincia de Guipúzcoa; ciudad de Huete, y Provincia de Castilla de la orden de Santiago; arcedianazgo de Talavera y obispado de Plasencia; arcedianazgo de Guadalajara; obispado de Cuenca, con el Infantazgo de Huete y el marquesado de Villena.

${ }^{143}$ A este total habría que sumar las 1.600 bulas entregadas en fecha desconocida por el receptor Juan Sánchez de Salinillas o Salinas al receptor Diego Martínez de Lerma.

144 Fuentes: AGS, EMR, leg. 8, ff. 922-923, 935-942, 999-1002, 1010-1013, 1016-1020, 1025-1029, 1036-1039, 1042-1045, 1048-1054 y 1063-1064. El gráfico recoge, por meses, el número total de cartas de bula recibido por los receptores de las siguientes circunscripciones: Medina del Campo, Arévalo, Olmedo, Madrigal, Alaejos, Castrejón, Valdefuentes y Bobadilla con sus tierras; merindades de Rioja y Logroño; merindad de Campos con Palencia, y Paredes de Nava; merindades de Saldaña, Aguilar de Campoo, Liébana, Pernía, Carrión y su arcedianazgo, sin Paredes de Nava; receptoría de Diego González de Ágreda; Vizcaya y provincia de Guipúzcoa; ciudad de Huete, y Provincia de Castilla de la
La continuidad de la entrega de cartas de bula a los receptores entre 1457 y 1462 (ver Gráfico 1) entraría teóricamente en contradicción con la limitación temporal de la vigencia de la cruzada otorgada por Calixto III a cuatro años, contados desde la fecha de recepción de la bula de concesión (1457-1460). A este elemento se vendría a sumar la suspensión de cualquier otorgamiento anterior, ordenada por el nuevo papa Pío II en el llamamiento general a la cruzada contra el Turco realizado el 14 de enero de 1460 (bula Ecclesiam Christi) como resultado del concilio reunido en Mantua desde comienzos de junio de $1459 .{ }^{145}$ No obstante, el 18 de enero de 1460 el papa daba licencia para que las bulas concedidas por su antecesor a favor de Enrique IV siguieran en vigor, aunque Pío II ordenaba que las sumas recaudadas se dividieran entre ambas empresas - la granadina y la turca-, lo cual suponía homologarlas de nuevo como parte del mismo proyecto unitario de lucha contra el infiel. ${ }^{146}$

Los nuevos llamamientos realizados por el pontífice para hacer frente a la amenaza turca tampoco dejarían en suspenso las bulas autorizadas por Calixto III para la guerra de Granada, motivo por el cual - como ha quedado señalado - la Real Hacienda pudo seguir ingresando en sus arcas recursos procedentes de la cruzada a lo largo de todo el bienio $1461-1462 .{ }^{147}$ Estas sumas serían complementadas con las procedentes del cobro del subsidio de 100.000 florines para la guerra contra el Turco aprobado en 1460 sobre las rentas eclesiásticas ${ }^{148}$ que, según la orden dada el 14 de febrero de 1462 por Pío II al nuncio Antonio de Veneris, debían compartirse con Enrique IV para su empleo en el conflicto con el emirato nazarí. ${ }^{149}$ De nuevo, el 12 de febrero de 1462 una nueva bula reiteraba la vigencia de las concesiones de Calixto III para la guerra de Granada, prorrogadas por tres años más para todos aquellos fieles del reino que abonasen 40 mrs. ${ }^{150}$

orden de Santiago; arcedianazgo de Talavera y obispado de Plasencia; arcedianazgo de Guadalajara; obispado de Cuenca, con el Infantazgo de Huete y el marquesado de Villena.

145 Valentini 1975: 249-282; Corradini 2006: 263-278.

146 Benito Ruano 1960: 299-301; Nieto Soria 1993: 333; ibídem 1996: 209.

147 Ibídem 1993: 333-334. El 12 de marzo de 1462 Pío II confirmaba las indulgencias concedidas por Calixto III a aquellos que tomasen parte en la guerra de Granada, exceptuándolos de la suspensión ordenada en el Concilio de Mantua. Benito Ruano 1960: 304-306.

148 La problemática sobre este subsidio, y las resistencias generadas entre el clero castellano en Nieto Soria 1993: 334-335.

149 Benito Ruano 1960: 301-302. Mención explícita al reparto del subsidio de 100.000 florines - mitad para el rey y mitad para el papaen AGS, CSR, leg. 97, f. 85r-v. De la recaudación efectiva de esta contribución eclesiástica ha quedado rastro en diferentes archivos catedralicios. El 17 de septiembre de 1460 el cabildo salmantino nombraba al canónigo Gonzalo López de la Torre como colector del subsidio del Santo Padre, encargado de su recaudación en el obispado de Salamanca, a presentación de Juan Rodríguez de Toro, deán de la catedral de Coria y canónigo en la catedral de Salamanca, que también ocupaba los cargos de provisor y vicario general del obispado salmantino previo nombramiento por el obispo Gonzalo de Vivero. Previamente al nombramiento se recibió notificación del nuncio apostólico Antonio de Veneris. Archivo Catedral de Salamanca, Actas Capitulares, 2, f. 302. Reg. Abad Raúl 2008: 356. En el caso del arzobispado toledano el 5 de enero de 1461 se daba en Toledo la carta de pago por valor de 9.780,5 florines en concepto de subsidio. Torija Rodríguez 2012: 220.

150 Nieto Soria 1993: 333-334. 
Todavía en 1464 el monarca castellano trató de aprovechar en su favor el contexto internacional en un último intento por revitalizar su imagen como «rey cruzado» y obtener nuevos frutos económicos a costa de la convocatoria papal. El 22 de junio de 1464 el rey ordenaba suspender en Castilla la predicación de la bula otorgada por Pío II contra el Turco hasta que su contenido fuese aclarado tanto por el papa como por una comisión integrada por el nuncio Veneris, algunos miembros del Consejo Real y ciertos maestros en Teología, pues existían dudas relativas a la aplicación de los beneficios recogidos en el documento de concesión. En la misma misiva se instaba a los predicadores a acudir a la corte para recibir de la mencionada comisión de expertos información sobre "lo que se deue predicar e dibulgar de la indulgencia de la dicha cruzada». Más allá del objetivo declarado de evitar los «errores e engaños» en la predicación que habrían llevado a muchos fieles a abandonar Castilla para luchar contra el Turco - la carta señala, de forma intencionalmente exagerada, que se esperaba el abandono de hasta 20.000 casas-, esta medida también pudo responder a un intento deliberado de la Corona por controlar la difusión del discurso que deseaba transmitir a sus súbditos. Acaso el objetivo final fuese consolidar una corriente de opinión favorable a la suspensión ordenada, que podría ser aprovechada para canalizar en favor de los intereses regios el estado emocional generado por el llamamiento papal contra los turcos. Por este motivo, la provisión real también informaba de la súplica realizada por Enrique IV al papa para que le fuesen concedidas las mismas indulgencias «a todos aquellos que fueren o enviaren comigo a la guerra de los moros del reino de Granada», que prometía reanudar, evitando así el desgaste de los súbditos castellanos que estaban dispuestos a luchar como cruzados en tierras lejanas y contra "gentes e naciones tan bárvaras e estrañas» como los turcos. ${ }^{151}$

Las reticencias de Enrique IV ante la convocatoria lanzada por Pío II cobraron un nuevo impulso avanzado el verano. El 6 de agosto de 1464, apenas ocho días antes del fallecimiento del pontífice en Ancona cuando esperaba la llegada de las naves venecianas que habrían de participar en la proyectada $-\mathrm{y}$ a la postre frustrada- expedición cruzada, el rey comunicaba a los prelados castellanos, al conde de Plasencia don Álvaro de Estúñiga, y a las justicias de las villas y lugares de Andalucía, el Principado de Asturias, la provincia de Guipúzcoa y el condado de Vizcaya, la petición presentada ante Pío II para que la cruzada e indulgencia plenaria otorgada para la lucha contra el Turco fuese reconocida con las mismas condiciones «a todos aquellos que comigo e por mi mandado fuesen contra los moros del reyno de Granada». La misma misiva volvía a prohibir bajo pena de cárcel, pérdida de "naturaleza» y embargo de bienes, la salida del reino de los hombres «de caballo» o "de pie» que habían respondido favorablemente al llamamiento papal, pues de nuevo se informaba de que «se esperavan muy en breve conseguir las mismas graçias e yndulgençias que eran otorgadas en la dicha cruzada». Una vez más, esta circunstancia se venía a sumar, a decir del rey,

151 Benito Ruano 1960: 308-311. Otra edición del mismo documento en Molina Grande 1988: 522-525. al engaño con el que acudían muchos de los combatientes que habían optado por tomar la cruz, instigados por predicadores que no había comprendido y difundido correctamente el contenido de la indulgencia. Finalmente, a todo ello se añadía el hecho de que, más allá de llegar "perdidos e gastados» a su destino, estos guerreros tampoco conocían la suspensión temporal de la cruzada contra el Turco como consecuencia de la enfermedad del papa y de la falta de compromiso de los reyes y príncipes europeos con el proyecto. ${ }^{152}$

\section{EL GASTO DE LA CRUZADA: INSTRUMENTALIZACIÓN PROPAGAN- DÍSTICA Y REALIDAD DOCUMENTAL}

Los problemas expresados en torno a la cuantificación del ingreso de la cruzada son extensibles al análisis del gasto de los recursos captados que, según expresan las cartas libradas desde mayo de 1457 por el rey en favor de los receptores encargados de recaudar las limosnas, serían aplicados únicamente a la guerra contra Granada, "e non en otras cosas nin nesçesidades algunas». ${ }^{153}$ Estas dificultades se acentúan si tenemos en cuenta que, a la falta casi total de documentación contable conservada, se suma la instrumentalización del destino de los fondos como arma de propaganda política realizada por los adversarios de Enrique IV. Estos no dudaron en deslegitimar la acción del rey resaltando el empleo del dinero de la cruzada en conceptos ajenos a su motivación inicial como acción contraria al reino, pero también a Dios, en virtud de la consideración "sacrílega» que podía adoptar el gasto realizado. No en vano, el confesor real fray Alonso de Espina, encargado de predicar la indulgencia en la corte tras la recepción de la bula calixtina en enero de 1457, ya había puesto especial énfasis en la obligatoriedad de destinar el monto recaudado, una vez descontada la parte destinada al mantenimiento de los predicadores y cogedores, exclusivamente en la "guerra de los moros». De lo contrario el monarca incurriría en «descomunion mayor, de la qual no podie ser assuelto sin perssonalmente requerir la sede apostolica». ${ }^{154}$

Los cronistas más hostiles al monarca inciden en este hecho, situando la mala gestión de los fondos percibidos como uno de los primeros motivos de descontento nobiliario con la política enriqueña. Alonso de Palencia apunta que, a fin de "conseguir el lucro que esperaba de la indulgencia», el rey únicamente recurrió en la campaña militar de 1456 a los caballeros más cercanos de su corte, entre los que figuraba el marqués de Villena y su hermano Pedro Girón, maestre de Calatrava, los 300 capitanes españoles y granadinos - caballeros moriscos-que le acompañaban regularmente, además de algunos grandes "aunque no en atavío de guerra», el arzobispo de Toledo Alonso Carrillo y la propia reina Juana. ${ }^{155}$ No obstante, la referencia al teórico beneficio económico extraído de la cruzada que habría obtenido el

152 La carta enviada a Jerez en Abellán Pérez s/a.: 239-241. La carta enviada a Murcia, de contenido idéntico, en Benito Ruano 1960: 311-314.

153 AGS, EMR, leg. 8, ff. 924-925.

154 Sánchez Parra 1991: 65. El relato de Valera es semejante. Valera 1941: 41.

155 Palencia 1973: I, 87. 
monarca gracias al ahorro derivado de la organización de una campaña de escasa envergadura no resiste la crítica, si tenemos en cuenta que la predicación y cobro generalizado de indulgencias no comenzó en Castilla hasta bien entrado 1457.

Por su parte, la Crónica anónima afirma genéricamente que de los maravedíes recaudados en concepto de cruzada «muy poca parte se gasto en la guerra de los moros, de lo qual todos los grandes del reyno fueron mucho turbados». ${ }^{156}$ La impresión es corroborada por Palencia, que destaca igualmente la indignación de algunos "grandes» una vez conocido el empleo de los 800.000 ducados percibidos en empresas al margen de la lucha contra el infiel «sin que de tan enorme cantidad se gastase una sola libra en la guerra de Granada». ${ }^{157}$ Ante esta situación, Pedro Fernández de Velasco, conde de Haro, habría sido el primer noble en dar un paso al frente "por reformar estos reynos, como convenía al serviçio de Dios e del rey y del bien común dello", concertando una confederación con el arzobispo de Toledo Alonso Carrillo, el almirante don Fadrique, el marqués de Santillana, los condes de Benavente y Alba, y otros caballeros y ciudades. ${ }^{158}$ El potencial peligro de esta alianza fue desactivado por Enrique IV gracias a la concordia suscrita con Juan de Navarra en las vistas de Alfaro de mayo de 1457, que alejaba cualquier posibilidad de intervención directa del magnate en los asuntos castellanos, y a la posterior mediación del marqués de Villena, el arzobispo de Sevilla y el contador mayor Diego Arias con el conde de Haro, al que trataron de convencer para que aplacase los ánimos del arzobispo de Toledo, el almirante y los restantes caballeros confederados. ${ }^{159}$ No obstante, resulta igualmente improbable que esta alianza nobiliaria pudiera realmente utilizar el gasto de la cruzada como elemento deslegitimador de la acción regia - al menos con conocimiento de causa-, si tenemos en cuenta que los primeros receptores y tesoreros encargados de la recaudación no fueron nombrados hasta fines de mayo de 1457, y que - a tenor de las cuentas conservadas - las primeras remesas de dinero recaudado no se libraron hasta octubre de $1457 .{ }^{160}$

Del mismo modo, tampoco existe constancia fehaciente de que Enrique IV entregase a Beltrán de la Cueva 80.000 florines «juntos» procedentes del rendimiento de la cruzada como afirma el autor de la Crónica anónima ${ }^{161}$, elemento que, sin embargo, serviría a sus enemigos para resaltar el fulgurante ascenso político y enriquecimiento del privado regio. En este mismo contexto habría que situar la mención realizada por Francisco de Medina y Mendoza, cronista del linaje mendocino, en la Vida del Cardenal D. Pedro González

156 Sánchez Parra 1991: 66. Valera afirma lo mismo. Valera 1941: 41.

157 Palencia 1973: I, 93.

158 Seguimos el relato de la Crónica anónima. El listado de nobles confederados aportado por Palencia únicamente incluye al conde de Haro, el arzobispo de Toledo, el Almirante y el conde de Alba.

159 Sánchez Parra 1991: 66-67. Palencia 1973: I, 93-94.

160 El primer pago conocido fue realizado por el receptor Diego González de Ágreda en favor de Ruy Fernández Morejón, receptor mayor, en la feria de octubre de Medina del Campo de 1457 (40.058 mrs). AGS, EMR, leg. 8, f. 1019.

161 Sánchez Parra 1991: 65. En la documentación correspondiente a Beltrán de la Cueva no se consigna ningún pago de esta naturaleza. Carceller Cerviño 2006. de Mendoza, redactada ya en el siglo XVI, a la junta reunida en 1459 en el castillo de Uceda por el entonces obispo de Calahorra Pedro González de Mendoza y el arzobispo de Toledo Alonso Carrillo, a la que fueron convocados muchos de los "grandes» a fin de que "se doliesen de la inobediençia de la yglesia», tras conocerse la supuesta entrega realizada por el rey a Beltrán de la Cueva y "otros sus privados» de mercedes con cargo a los fondos de la cruzada «de manera que no se consiguió del dinero della el fin del Papa». ${ }^{162}$ En este sentido, la malversación de fondos procedentes de la cruzada como recurso difamatorio contra la privanza de Beltrán de la Cueva se situaba en la estela de algunas de las acusaciones vertidas en la misma dirección durante el reinado de Juan II contra don Álvaro de Luna en el contexto de su pugna con los infantes de Aragón, para desprestigiar su imagen política a partir de su supuesto enriquecimiento mediante el disfrute de rentas eclesiásticas o destinadas a la lucha contra el infiel. ${ }^{163}$

Almargendetodasestasafirmaciones, muycondicionadas por el uso que la propaganda anti-enriqueña hizo a posteriori de la gestión de la cruzada, y con independencia de su grado de veracidad, los fragmentos contables conservados, que en este caso se refieren únicamente a siete receptorías, aportan datos que permiten abordar parcialmente desde una perspectiva "no intencional» la cuestión del gasto de los recursos captados.

Así, la lectura de las cuentas de los receptores conservadas refleja en primer lugar trasvases de dinero realizados a favor de Ruy Fernández de Morejón, receptor mayor de distintas cantidades de la cruzada entre al menos octubre de $1457^{164}$ y el 19 de septiembre de $1458 .{ }^{165}$ Este oficial, mencionado en otras fuentes como vecino de Medina del Campo y escribano ${ }^{166}$, centralizó en un primer momento los recursos

162 Francisco de Medina y Mendoza refiere la asistencia a la Junta de Uceda de varios miembros del linaje mendocino, como Diego Hurtado de Mendoza y sus hermanos Lorenzo Suárez e Íñigo López de Mendoza, todos ellos hijos del marqués de Santillana Íñigo López de Mendoza. Medina y Mendoza 1853: 159. La datación de la Junta de Uceda en ibídem: 163-164.

163 Uno de los aspectos señalados en el escrito remitido por los infantes de Aragón a Juan II, firmado en Medina de Rioseco el 20 de febrero de 1439 , en el que se instaba al monarca a apartar de la corte al Condestable, hacía precisamente referencia a la toma fraudulenta de rentas regias y a la conformación de un importante tesoro en Venecia y otros lugares fuera del reino por parte del privado regio. En este sentido, el texto incluido en la Crónica del Halconero llega a referir cómo don Álvaro «puso las manos en los florines de la villa de Marchena, e de la cruzada, e aun es de crer que las porná en lo que agora an de dar los perlados e clérigos», en referencia al subsidio aprobado para el bienio 1438-1439. Carrillo de Huete 1946: 326. Sobre el subsidio de 1438-1439 ver Villarroel González 2011: 327. El cobro de este subsidio también está certificado por la carta de pago dada el 6 de octubre de 1440 por el canónigo Álvaro Yanes en favor de Teresa de Figueroa, II señora de Villagarcía, por la entrega de $750 \mathrm{mrs}$ en concepto de subsidio eclesiástico. SNAHN, Osuna, Cp. 82, doc. 21.

164 Cuenta de los mrs que Diego González [de Ágreda] ha dado y pagado de su receptoría de la Santa Cruzada. AGS, EMR, leg. 8, ff. 1019-1020.

165 Cuenta de los mrs que Juan Sánchez de Salinas ha dado y pagado de su receptoría de la Santa Cruzada. AGS, EMR, leg. 8, ff. 1028-1029.

166 Castro Toledo 1981: docs. 624 y 627. Al margen de estas menciones, la única referencia localizada sobre este personaje figura en la carta ejecutoria dada el 9 de octubre de 1487 en el pleito litigado por Ruy Fernández Morejón, vecino de Bobadilla del Campo (Valladolid) con el concejo de Bobadilla sobre el arrendamiento de alcabalas. Según 
obtenidos en las campañas de predicación -en total 1.952.730 mrs procedentes de los partidos cuyas cuentas conocemos, equivalentes al $10 \%$ del total abonado por estos receptores-, quizás aprovechando su avecindamiento en una de las plazas que más pagos concentraba ya en aquel momento. ${ }^{167}$ Sin embargo, la pérdida de sus cuentas impide conocer el destino último otorgado a estas sumas $y$, por lo tanto, corroborar o desmentir los datos aportados por los diferentes cronistas.

Ruy Fernández Morejón fue remplazado en su actividad principal por el judeoconverso Diego Arias Dávila, ${ }^{168}$ contador mayor del rey y "hombre fuerte» de Enrique IV en los asuntos hacendísticos, que desde enero de 1460 centralizó en sus manos por mandato regio todas las cuantías enviadas a la corte y cámara real por los recaudadores del variado conjunto de rentas y derechos que percibía la Corona en aquel momento. ${ }^{169}$ En lo que se refiere a la cruzada, el cargo de los maravedíes recibidos por el contador mayor entre el 1 de mayo de 1461 y fines de septiembre de 1462 para atender a diversos gastos incluye un total de 6.586.303 mrs procedentes del rendimiento de la predicación de indulgencias en todo el reino, además de 16.220 florines ( $2.270 .800 \mathrm{mrs}$ a $140 \mathrm{mrs} /$ florín) del subsidio aprobado en 1461, recibidos previa autorización del nuncio apostólico y colector Antonio de Veneris. ${ }^{170}$

A estas cuantías, no obstante, habría que añadir los maravedíes percibidos por Arias Dávila desde al menos diciembre de $1457^{171}$ «para fazer d'ellos las cosas que Su Señoría mandase», "para tener en la corte para serviçio del rey» o "para las cosas conplideras a serviçio del dicho señor rey», que son algunos de los conceptos genéricos utilizados

parece, Ruy Fernández Morejón había sido arrendador y recaudador mayor de las alcabalas y tercias de la villa de Medina del Campo y de los lugares y señoríos de Bobadilla y otros en 1469, 1470 y 1471. ARCV, Ejecutorias, Caja 10, exp. 37.

167 La cuenta de Diego González [de Ágreda] refiere el pago en la feria de Medina del Campo de octubre de 1457 de 40.058 mrs realizado a favor de Ruy Fernández Morejón, recibidos por Juan de Herrera. AGS, EMR, leg. 8, f. 1019.

168 No obstante, en la cuenta de Diego Arias Dávila se menciona un pago de 200.000 mrs «en cuenta de su reçebtoría» realizada por Ruy Fernández Morejón, «reçebtor de çiertos mrs que le fueron librados en çiertos thesoreros de la dicha cruzada», por albalá del rey dado el 10 de mayo de 1462. AGS, CSR, leg. 97, f. 81r.

169 Estos recursos procedían de las siguientes fuentes de renta: dineros de la «cámara» cobrados en el realengo y en el Principado, servicios de Cortes, moneda forera, bula de Cruzada y subsidio eclesiástico, rentas de la «mesa maestral» de la orden de Santiago, derechos de las casas de la moneda, albaquías o deudas, y derechos de recaudamiento. Sobre la receptoría de Diego Arias Dávila ver Ladero Quesada 2009b: 545-561.

170 Ibídem: 552. Entre los «asientos» contables del cargo de Diego Arias Dávila se encuentra el siguiente: «Del reverendo dotor miçer Antonio de Veneris, nunçio e coletor de nuestro Santo Padre, çinco mill florines de oro de Aragón en cuenta de los çinquenta mill florines que ovo a dar al dicho señor rey de los çient mill florines del subsidio que el dicho nuestro Santo Padre mandó repartyr por las clerezías e yglesias melitares de los regnos e señoríos del dicho señor rey, de los quales dichos çinco mill florines yo di mi carta de pago firmada de mi nombre al dicho nunçio» (fecha de la carta de pago: 1461-mes en blanco-día en blanco). AGS, CSR, leg. 97, f. 85r-v.

171 El primer pago conocido en favor de Diego Arias Dávila figura en la cuenta del receptor Fernando Díaz de Alcocer, y fue librado por carta del rey dada en Medina del Campo el 20 de diciembre de 1458. AGS, EMR, leg. 8, f. 1044. para aludir al dinero líquido entregado al monarca para los gastos de su cámara y Casa, y para su libre disposición personal o política. En este sentido, las menciones a estas remesas incluidas en las cuentas de los receptores de la cruzada confirman la hipótesis de M. Á. Ladero Quesada referida al desempeño por parte de Arias Dávila del cargo de receptor de las sumas que llegaban a la corte regia con anterioridad a 1460. ${ }^{172}$ Además de estas cantidades, las mismas cuentas de la cruzada también incluyen pagos a Diego Arias Dávila fechados durante el bienio 1461-1462 que no fueron anotados en el cargo o ingreso del contador mayor por motivo desconocido. ¿Constituye este hecho un indicio del aprovechamiento fraudulento de la cruzada denunciado por Alonso de Palencia, que llega a afirmar en tono difamatorio de Arias Dávila que «con pretexto de la concesión apostólica, iba recaudando sumas inmensas, destinadas más bien a la ruina de las virtudes que al exterminio de los moros?». ${ }^{173}$

En cualquier caso, solo las cuentas de las siete receptorías conocidas registran pagos al contador mayor por casi $16.000 .000 \mathrm{mrs}$ (78\% del total conocido), muchos de ellos cobrados en su nombre por algunos de sus criados - Juan de Herrera, Pedro de Aguilar, Juan de Roa o Álvaro de Lugo-, de manera que cabe suponer que el total ingresado por Arias Dávila en concepto de cruzada fue mucho mayor al reflejado en la cuenta de su cargo (6.586.303 mrs). Aunque de nuevo la pérdida de la data de Diego Arias Dávila impide realizar valoraciones concluyentes sobre la adecuación del gasto de las sumas recaudadas a la finalidad perseguida en los documentos de concesión, lo cierto es que la centralización de la mayor parte del ingreso de la cruzada en sus manos otorgaba al rey una enorme libertad de acción frente a las limitaciones teóricas establecidas en las bulas papales, al no existir un control eficaz por parte de los delegados pontificios sobre el destino dado al monto recaudado, similar al efectuado por el nuncio apostólico y colector Antonio de Veneris sobre el cobro del subsidio. ${ }^{174}$

Además de los pagos a Ruy Fernández Morejón y Diego Arias Dávila, las siete cuentas de cruzada conocidas también incluyen un total de 63 asientos (ver Apéndice final) con datos referidos a la entrega directa por parte de los receptores de sumas destinadas al pago de sueldos militares. Estos pagos comenzaron en abril de 1460 , momento en el que las campañas de predicación se encontraban en una fase muy avanzada, y se prolongaron hasta una fecha tan tardía como diciembre de 1465, cuando el reino se encontraba ya dividido en dos obediencias y parte del remante del dinero de la cruzada pudo servir para pagar el sueldo de algunos vasallos leales a Enrique IV. ${ }^{175}$ No obstante, la mayor parte

\footnotetext{
172 Ladero Quesada 2009b: 545.

173 Palencia 1973: I, 107; Goñi Gaztambide 1958: 365.

174 Sobre su actividad en Castilla desde 1457 ver Nieto Soria 1996:

175 Por ejemplo, en diciembre de 1465, cuando la situación política y económica de Enrique IV se encontraba enormemente comprometida tras su destronamiento en efigie, el rey llegó a ordenar a Fernando Díaz de Alcocer, receptor de la cruzada en el arcedianazgo de Guadalajara, pagos por una cuantía total de $45.800 \mathrm{mrs}$ para el sueldo adeudado a varios vasallos leales (Gonzalo de Olmedo, Juan de Medina, Juan de Arévalo, Martín de Córdoba, Pedro López de Toledo y Pedro de Córdoba) «para cada tres lanças con pajes que han tenido en su serviçio este dicho
} 176-177. 
TABLA 6

Resumen de los pagos conocidos con cargo a las sumas recaudadas en concepto de cruzada desde $1457^{176}$

\begin{tabular}{|l|c|c|c|}
\hline \multirow{2}{*}{\multicolumn{1}{|c|}{ Partido/ circunscripción }} & \multicolumn{2}{c|}{ Destinatarios de los pagos (mrs) } \\
\cline { 2 - 4 } & $\begin{array}{c}\text { Ruy Fernández } \\
\text { Morejón }\end{array}$ & Diego Arias Dávila & $\begin{array}{c}\text { Pago directo de } \\
\text { sueldos militares }\end{array}$ \\
\hline Valladolid, Infantazgo & 514.340 & 606.596 & 175.823 \\
\hline Rioja y Logroño, merindades & 861.203 & 6.378 .668 & 1.237 .976 \\
\hline $\begin{array}{l}\text { Saldaña, Aguilar de Campoo, Liébana, Pernía, Carrión y su } \\
\text { arcedianazgo, merindades, sin Paredes de Nava }\end{array}$ & 47.712 & 1.929 .513 & 60.230 \\
\hline $\begin{array}{l}\text { Receptoría de Diego González de Ágreda, de partidos } \\
\text { desconocidos }\end{array}$ & 92.658 & 1.367 .365 & 57.998 \\
\hline $\begin{array}{l}\text { Vizcaya, condado y señorío, con las Encartaciones, la Provincia de } \\
\text { Guipúzcoa y la merindad de Allendebro }\end{array}$ & 331.817 & 4.435 .570 & 480.654 \\
\hline Guadalajara, arcedianazgo & 45.000 & 557.363 & 138.330 \\
\hline Cartagena, obispado, con el reino de Murcia & 60.000 & 689.985 & 448.593 \\
\hline TOTAL (MRS) & $\mathbf{1 . 9 5 2 . 7 3 0}$ & $\mathbf{1 5 . 9 6 5 . 0 6 0}$ & $\mathbf{2 . 5 9 9 . 6 0 4}$ \\
\hline \% SOBRE EL TOTAL (20.517.394 mrs) & $\mathbf{1 0}$ & & $\mathbf{7 8}$ \\
\hline
\end{tabular}

de ${ }^{176}$ las cuantías asociadas a este concepto fue abonada durante el bienio 1461-1462 en un contexto de relativa estabilidad interna. ${ }^{177}$

En total, estos desembolsos suponen casi 2.600 .000 mrs (12\% del total de gasto conocido), destinados fundamentalmente a abonar el "sueldo" y «acostamiento» de las tropas movilizadas en conflictos que nada tenían que ver con la contienda granadina - fundamentalmente la guerra contra Navarra de $1461-$, y a la retribución de los servicios militares prestados por diferentes vasallos reales y algunos de los nobles y cortesanos más próximos al monarca hasta el estallido de la crisis política en 1464.

Entre estos últimos beneficiarios encontramos figuras políticas de primer orden, empezando por el marqués de Villena don Juan Pacheco, que recibió algunas sumas para pagar las mesnadas movilizadas para sofocar la revuelta de Pedro Fajardo en Murcia ${ }^{178}$, y las tropas enviadas a Ocaña con el objetivo de hacer frente, por consejo del rey, a las gentes del arzobispo de Toledo "y de sus amigos», y facilitar un acuerdo. ${ }^{179}$ Su hermano Pedro Girón, maestre de Calatrava, recibió con cargo a la cruzada al menos 900.000 mrs para el

año». AGS, EMR, leg. 8, f. 1045. Cabe suponer que estas cantidades procedían del remanente de las campañas de predicación desarrolladas entre 1457 y 1461 que todavía quedaba en manos del tesorero.

176 Fuentes: AGS, EMR, leg. 8, ff. 941-942, 1012-1013, 1019-1020, 1028-1029, 1044-1045, 1053-1054 y 1063-1064.

177 Ladero Quesada 1991: 237-274.

178 El 19 de diciembre de 1460 Enrique IV firmaba la orden para que don Juan Pacheco y Pedro Girón combatiesen a Pedro Fajardo, que resistió hasta la toma de Caravaca el 7 de diciembre de 1461. Sobre la revuelta murciana ver el trabajo de Torres Fontes 2001.

179 Los pagos, librados en Diego de Alcalá, receptor de la cruzada en el obispado de Cartagena y reino de Murcia, son los siguientes: 121.795 mrs para el sueldo de 150 lanzas que tuvo el marqués de Villena en 1461 al servicio del rey en Ocaña hasta su licencia el 27 de agosto; 73.022 mrs para el sueldo de 50 lanzas que tuvo «en 1461 en la guarda» hasta el 25 de noviembre en que fueron despedidas 30; y 109.235 mrs para el sueldo de 4 lanzas y 150 peones movilizados el mismo año contra Alonso Fajardo, hasta su despido el 23 de octubre. AGS, EMR, leg. 8, ff. 10631064. La movilización de tropas para reforzar la guarnición de Ocaña es relatada en Palencia 1973: I, 127. pago de las 1.500 lanzas de «hombres de armas» y «de la jineta» destacadas en Navarra y su frontera. ${ }^{180}$ Asimismo, las cuentas también reflejan cantidades destinadas al pago de sueldos militares entregadas directamente por los receptores al contador mayor Diego Arias Dávila ${ }^{181}$, y a sus hijos Pedro Arias Dávila, que le sucedió en su oficio hacendístico y fue nombrado capitán general en la guerra de Navarra ${ }^{182}$, y Juan Arias Dávila, obispo de Segovia. ${ }^{183}$ La nómina también incluye a importantes eclesiásticos próximos al círculo enriqueño, como el arzobispo de Santiago Alonso de Fonseca - sobrino del arzobispo de Sevilla homónimo, que tenía destacadas 1.500 lanzas en Valladolid ${ }^{184}$ - , el obispo de Osma Pedro García de Huete o de Montoya - que también movilizó tropas en la frontera de Navarra ${ }^{185}$-, o el obispo de Cuenca Lope de Barrientos. ${ }^{186}$ Finalmente, encontramos pagos de

180900.000 mrs por el sueldo de 1.500 lanzas de «hombres de armas» y «de la jineta» puestas al servicio del rey en 1461 en Navarra y su frontera. AGS, EMR, leg. 8, ff. 941-942 y 1053-1054. La movilización de don Pedro Girón es corroborada por Alonso de Palencia, que señala el Ilamamiento que hizo Enrique IV al maestre de Calatrava «para encaminarse con el ejército a Logroño, ciudad fronteriza de Navarra, a orillas del Ebro». Palencia 1973: I, 127.

181100.000 mrs por el sueldo de las lanzas que en 1461 tuvo en servicio del monarca hasta su despido.

$18215.388 \mathrm{mrs}$ para las 40 lanzas y jinetes movilizadas hasta fines de agosto de 1461 y otras 6 hasta que fueron despedidas.

$18322.844 \mathrm{mrs}$ para el sueldo de 21 lanzas y jinetes de 1461. Sobre la familia Arias Dávila ver Álvarez Rubiano 1944; Cantera Burgos 1971.

$18470.297 \mathrm{mrs}$ para el sueldo de 1.500 lanzas que tomó en Valladolid hasta su despido el 8 de septiembre de 1461 . Otro asiento señala el pago de 50.000 mrs realizado por Diego Rodríguez de Dueñas, receptor de la cruzada en el infantazgo de Valladolid, al escribano de cámara del rey Alfón de Córdoba, «para que d'ellos pague sueldo de çierto tienpo al arçobispo de Santiago e conde de Osorno e a otras çiertas personas que por mandado del dicho señor rey han estado e están en la villa de Valladolid».

18552.322 mrs para el sueldo de las lanzas que tenía «en la guarda» hasta su despido, y otros 12.730 para el sueldo de la gente que llevó a la frontera de Navarra. Pedro de Montoya había formado parte del Consejo Real en época de Juan II y era miembro de la Audiencia Real, aunque mostró su oposición al rey tras la sublevación nobiliaria de 1465 . Nieto Soria 1993: 160.

$18640.000 \mathrm{mrs}$ de su «acostamiento» de 1461. 
menor entidad a otros miembros del estamento nobiliario, como el conde de Benavente don Rodrigo Pimentel ${ }^{187}$, el conde de Osorno, el señor de Teba Juan de Guzmán ${ }^{188}$, o el capitán Íñigo Ortiz de Estúñiga. ${ }^{189}$

No obstante, tal y como se apuntaba, el grueso de estos pagos directos de carácter militar fue destinado a sufragar los gastos de la guerra de Navarra iniciada en el verano de 1461 en el marco del conflicto sostenido con Juan II de Aragón, motivado por el apoyo que Enrique IV brindaba al príncipe Carlos de Viana - hijo del monarca aragonésen la disputa que sostenía con su padre, y posteriormente por la cesión de Navarra al rey de Castilla realizada por su antigua esposa Blanca, heredera del trono tras la muerte del príncipe Carlos en septiembre de $1461 .{ }^{190}$ Además de las libranzas ordenadas en favor de Pedro Girón, Pedro Arias Dávila y el obispo de Osma para el pago de las tropas desplazadas a la frontera de Navarra en 1461, encontramos otros desembolsos realizados por los receptores de la cruzada de las merindades de Rioja, Logroño, y de los territorios vascongados, que eran zonas próximas al escenario del conflicto bélico.

Por ejemplo, Antón de Baena, vasallo del rey, recibió en fecha no especificada al menos $300.000 \mathrm{mrs}$ de la cruzada para pagar por mandato del rey el sueldo de la gente de armas destacada en Navarrete - villa situada a 8 km de Logroño-, mientras que entre el 13 de agosto y el 29 de septiembre de 1461 Enrique IV ordenaba en varios albalaes a los receptores García Martínez, Juan Sánchez de Salinas y Diego González de Ágreda llevar a Logroño 361.200 mrs de la cruzada para su entrega al escribano de cámara Diego de Çetina, encargado a su vez de pagar el sueldo a la gente "de cavallo e de pie» que servía al rey en ciertos castillos de Navarra. Finalmente, las obras realizadas en algunas fortalezas fronterizas también fueron sufragadas, en parte, con cargo a estos mismos recursos. Así lo constata la entrega ordenada al receptor Juan Sánchez de Salinas por el rey el 30 de julio de 1461 de 49.900 mrs a Diego de Vergara y Diego de Corcuera, antiguo alcaide de Clavijo, para los gastos realizados en los castillos de Jubera y Clavijo. ${ }^{191}$ Ello confirma el empleo de importantes sumas procedentes de la cruzada en la financiación de este conflicto, al cual también se destinaron al menos 4.633 florines del subsidio (648.620

18720.000 mrs en cuenta de 100.000 mrs que el rey le mandó librar en 1462 para su «ayuda de costa» y el sueldo de cinco meses.

$1886.022 \mathrm{mrs}$ del sueldo que debía recibir para 15 jinetes hasta su despido.

189 Por carta de libramiento del rey (1461-10-2. Madrid) se ordenó el pago de $13.547 \mathrm{mrs}$ «que los ovo de aver de sueldo de çinco días para çierta gente de cavallo e de pie que tovo ayuntada por mandado del rey este dicho año».

190 Desarrollo fáctico del conflicto y análisis de las diferentes alianzas en Suárez Fernández 2001: 222-231; Martín Martín 2002: 111-113 y 115-133.

191 Por albalá del rey (1461-7-30) Juan Sánchez de Salinas, receptor del condado y señorío de Vizcaya, con las Encartaciones, la Provincia de Guipúzcoa y la merindad de Allendebro, recibió orden de pagar a Diego de Vergara y Diego de Corcuera, alcaide que fue de Clavijo 49.900 mrs "por çierto sueldo e trastos en esta guisa: al dicho Diego de Vergara $36.700 \mathrm{mrs}$ de çierto sueldo e costas que fizo en la fortaleza de Jubera, e al dicho Diego de Corcuera 13.200 mrs de çiertos onbres e gastos e reparos que fizo en la fortaleza de Clavijo». AGS, EMR, leg. 8, ff. 1028-1029. mrs), entregados al maestre de Calatrava para el pago de las tropas movilizadas, según albalá del rey dado el 8 de julio de 1461 al nuncio Antonio de Veneris. ${ }^{192}$

Si el desvío de recursos económicos procedentes de la venta de indulgencias y del subsidio en fines ajenos a la guerra de Granada - prácticamente paralizada entre 1458 y 1462 como consecuencia de las sucesivas treguas firmadas y renovadas con el emirato nazari ${ }^{193}$ - pudo pasar desapercibido a nivel político en un momento de relativa calma interna, lo cierto es que a partir de 1464, cuando el consenso en torno al gobierno de Enrique IV se rompía de forma definitiva, los instigadores del levantamiento nobiliario no dudaron en amplificar en sus denuncias el mal uso dado a la cruzada. El objetivo no era otro que atacar la posición del monarca alegando su falta de compromiso con las obligaciones religiosas que como "rey católico» tenía asignadas y de mermar, con ello, el apoyo brindado por el pontificado desde comienzos de su reinado. ${ }^{194}$

Según Alonso de Palencia, el mensajero enviado a Roma por el arzobispo de Toledo Alonso Carrillo una vez conocida la súplica del monarca para que el papa otorgase a Beltrán de la Cueva el maestrazgo de Santiago -que según el testamento de Juan II debía corresponder al infante Alfonso-, incluyó entre los argumentos expuestos ante Pío II para difamar a Enrique IV, además del desprecio del rey a la religión y su simpatía hacia los moros, "la exacción de 800.000 ducados por la Bula de cruzada, parte consumidos en torpes empleos y parte encerrados en el real tesoro». ${ }^{195}$ El razonamiento del emisario de Carrillo habría sido ignorado por el papa, que en aquel momento se encontraba mucho más pendiente de organizar su proyecto de cruzada contra el Turco, aprovechado por el monarca castellano para obtener de la convocatoria nuevos beneficios en términos económicos y de propaganda política. ${ }^{196}$ No obstante, la muerte de Pío II en Ancona el 14 de agosto de 1464 avocaba al fracaso el último intento

192 El «asiento» del cargo de Diego Arias Dávila señala lo siguiente: «Del dicho dotor miçer Antonio, nunçio del dicho Santo Padre, quatro mill e seysçientos e treynta e tres florines en cuenta de los dichos çinquenta mill florines que ovo de dar al dicho señor rey del dicho subsidio, los quales me pagó por él el maestre de Calatrava por un alvalá del dicho señor rey, por el qual dicho alvalá el dicho señor rey me mandó que diese al dicho maestre los dichos florines en cuenta de los mrs del sueldo que del dicho señor rey ovo de aver para la gente que traxo e tovo en su serviçio el dicho año de sesenta e uno en la frontera de Navarra, de los quales dichos di al dicho maestre un alvalá del dicho señor rey fecho ocho días de jullio del dicho año de sesenta e uno por do su señoría mandó al dicho señor nunçio que me diese los dichos florines de los quales di mi carta de pago al dicho maestre de cómo los resçebí del dicho maestre en la dicha carta de pago que de los dichos florines le di para el dicho nunçio que es fecha el dicho día ocho de jullio, por las quales dichos quatro mill e seysçientos e treynta e tres florines yo cargo sobre mí seysçientas e quarenta e ocho mill e seysçientos e veynte mrs que en los dichos florines monta, contados a razón de çiento e quarenta mrs cada un florín, segund a la sazón vale». AGS, CSR, leg. 97, f. 86r.

193 Ladero Quesada 2002: 45-46.

194 Nieto Soria 1996: 178.

195 Palencia 1973: I, 152; Nieto Soria 1993: 332. Las denuncias de Carrillo ante Pío II también son recogidas por Galíndez de Carvajal 1946: 151.

196 La bula de Pío II en la que se ofrecía la indulgencia plenaria a aquellos que respondiesen al llamamiento para luchar contra el Turco fue notificada a Enrique IV en Madrid por el nuncio Antonio de Veneris. Benito Ruano 1960: 309. 
de Enrique IV por restaurar su imagen de "rey cruzado» contando con el apoyo pontificio, en un contexto marcado por el agravamiento de la crisis del reino al que se asiste desde septiembre del mismo año.

En este convulso escenario, el destino de los fondos procedentes de la cruzada predicada desde 1457 volvió a situarse en el punto de mira de la nobleza levantisca como elemento de crítica, a pesar de que el propio papa se había encargado de legitimar en marzo de 1462 cualquier uso fraudulento del dinero recaudado absolviendo al rey, previa confesión, de las censuras en que hubiera podido caer al emplear fondos de la cruzada en empresas ajenas a la finalidad declarada, a cambio de su compromiso para reanudar la guerra contra Granada. ${ }^{197}$ Ignorando esta circunstancia, el memorial de agravios que los prelados y nobles conjurados remitieron al monarca el 28 de septiembre de 1464 incluye reproches muy explícitos sobre el destino otorgado a las rentas obtenidas durante su reinado - entre ellas las derivadas de la "santa cruzada" y el subsidio obtenido de los papas «so color de faser guerra a los moros»-, alejado de las motivaciones finales que podían legitimar su percepción, entre ellas el "servicio de Dios», la defensa de la fe, la administración de la justicia del reino, y el «bien de la república». ${ }^{198}$

\section{CONCLUSIÓN}

A pesar de sus limitaciones, la documentación contable conservada confirma la libertad con la que Enrique IV pudo utilizar el producto de la bula de cruzada otorgada por Calixto III en empresas que respondían a sus intereses políticos más inmediatos, sin ajustarse a la finalidad teórica perseguida en los documentos de concesión pontificia. Lejos de suponer una novedad, con ello se daba continuidad a una práctica relativamente frecuente ligada al aprovechamiento por parte de la monarquía de fuentes de renta que requerían de la aprobación pontificia como elemento característico del «Estado fiscal» castellano a fines de la Edad Media. En este sentido, más allá de la instrumentalización realizada por el bando anti-enriqueño del uso ilegítimo dado al producto de la venta de indulgencias como elemento de crítica política, lo cierto es que la cruzada percibida desde 1457 llevó aparejada una serie de novedades frente a concesiones anteriores.

En primer lugar, el particular contexto internacional que habilitaba la expansión del Turco en el Mediterráneo oriental fue hábilmente aprovechado por la monarquía castellana para vincular los llamamientos generales a la cruzada lanzados por Calixto III y Pío II a toda la cristiandad con la particular guerra librada por Castilla contra Granada. Esta circunstancia, más allá de aportar un cauce de legitimación a la hora de plantear la solicitud de nuevas concesiones pontificias, aportaría desde 1457 una vía de financiación extraordinaria a las arcas reales con la que, teóricamente, se habría de sufragar el proyecto político enriqueño de unidad en torno a la lucha contra Granada planteado desde los inicios de su reinado.
En segundo lugar, aunque carecemos de datos previos con los cuales realizar comparaciones de tipo cuantitativo, es muy probable que el rendimiento fiscal de las concesiones pontificias se viera incrementado en virtud de la rebaja de la limosna acordada, y de la posibilidad de ampliar las indulgencias a los difuntos, reconocida - a pesar del debate teológico suscitado- por primera vez en 1456. A estos elementos habría que añadir al control ejercido por la Corona sobre la colecta, realizada al margen de la actividad desplegada por los delegados pontificios y puesta en manos de receptores afines al poder regio, que pudieron utilizar sus oficios para consolidar posiciones económicas y políticas en sus respectivos ámbitos de implanación, tal y como se desprende del análisis prosopográfico de gestores realizado.

Finalmente, y a pesar de lo limitado de las conquistas militares obtenidas frente a Granada (Estepona, Gibraltar y Archidona), y del desvío de fondos para la financiación de empresas alejadas de la finalidad que había motivado la concesión papal - como la guerra de Navarra-, lo cierto es que las bulas otorgadas por Calixto III a Enrique IV permitieron difundir, con relativo éxito inicial, una imagen carismática del monarca castellano como "rey cruzado» a partir de la construcción de un discurso que reforzaba su liderazgo político al frente del reino. En este sentido, pese a su virulencia, la posterior propaganda y difamación anti-enriqueña no lograría borrar de forma completa esta imagen de la «memoria política». Así se aprecia, por ejemplo, en el relato de los principales acontecimientos sucedidos en Castilla entre 1454 y 1536 realizado en la Crónica anónima castellana, que probablemente hay que identificar con la segunda parte del Catálogo real de los reyes de Castilla de Gonzalo Fernández de Oviedo. El texto, que para la época de Enrique IV sigue de cerca el relato del cronista Enríquez del Castillo, ofrece una imagen marcadamente favorable del monarca como impulsor de la lucha contra el infiel que «como a deboto y religioso príncipe convenía hazer, teniendo tanta devoçión y fee y industria como los cathólicos príncipes han de tener para guerrear contra los moros». ${ }^{199}$ Esta idea contrasta con la imagen de debilidad frente a Granada, y de depredación de los recursos fiscales otorgados por el pontificado para la guerra contra el emirato nazarí, presentada por Alonso de Palencia o por el autor de la Crónica anónima que, con independencia de su grado de veracidad, ha primado tradicionalmente a la hora de construir la "memoria» de la acción política enriqueña durante los primeros años de su reinado.

\footnotetext{
197 Benito Ruano 1960: 302-303. Goñi Gaztambide, J. 1958: 367.

198 Memorias de Don Enrique IV de Castilla. Vol. 2. 1835-1913: 330.
}

\footnotetext{
199 Nieto Soria 2015: 108.
} 


\section{APÉNDICE}

\section{DOCUMENTO 1}

\section{7-6-14. S.I.}

Traslado del recaudo que Alfón Arias, hijo de Juan Álvarez de Mercado, vecino de la villa de Arévalo, hizo de la receptoría de la Santa Cruzada de la villas de Medina del Campo, Arévalo, Olmedo, Madrigal, Alaejos, Castrejón, "Valle Fuentes» [Valdefuentes] y Bobadilla, y sus tierras.

\section{AGS, EMR, leg. 8, ff. 920-921}

Señores contadores mayores de nuestro señor el rey.

Bien sabedes que Su Alteza proveyó de la reçebtoría de los mrs de las bullas de la Santa Cruzada de las villas de Medina del Canpo e Arévalo e Olmedo e Madrigal e Alahejos e Castrejón e Val de Fuentes e Bobadilla e sus tierras a Alfón Arias, fijo de Juan Álvarez de Mercado, vezino de la villa de Arévalo, e sobr'ello le mandó dar e dio su carta firmada de su nombre e sellada con su sello e librada de vosotros señores, e agora sabed que por ante mí Gonçalo Garçía de Llerena, escrivano de cámara de nuestro señor el rey e su notario público en la su corte e en todos los sus regnos e señoríos el dicho Alfón Arias se obligó de dar e pagar al dicho señor rey o a quien por Su Alteza lo oviere de aver e de recabdar de cada una de las cartas que de las dichas bullas de la dicha Santa Cruzada resçibiere él o otro por él çiento e çinquenta mrs d'esta moneda usual que dos blancas viejas o tres nuevas valen un maravedí entera e conplidamente syn descuento alguno, puestos en la su corte en la su cámara a su ventura e costa e misión desde el día qu'él o otro por él resçibiere las dichas cartas de las dichas bullas en adelante de tres en tres meses como se fueren dando e destribuyendo o ante sy ante los oviere resçibido e el dicho señor rey le enbiare mandar que los traya so pena del doblo por pena e por postura e por nonbre de ynterese comerçió mal, a la quel dicha pena se obligó sy en ella cayere como al dicho debdo prinçipal con todas las costas e daños e menoscabos que sobr'ello fizieren e recresçieren fasta los cobrar, e los çinquenta mrs fyncables a conplimiento de los dozientos mrs que de cada una de las dichas cartas han de pagar los que las asy tomaren e resçibieren el dicho Alfón Arias, reçebtor, los ha de aver para que d'ellos pague los derechos que son ordenados por el dicho señor rey que ayan d'ellas el arçobispo de Sevilla e vos los dichos contadores mayores e las otras personas a quien el dicho señor rey los manda dar segund se contiene en un su alvalá que para vosotros señores mandó dar, que está asentado en los sus libros, e para su salario por el resçibir e recabdar de los dichos mrs de las dichas cartas, e por el traher d'ellos a la cámara del dicho señor rey e para los otros gastos e despensas, asy de los predicadores que han de predicar la dicha Santa Cruzada como de los pendones e tronpetas e otras costas e gastos que en lo sobredicho se fizieren e gastaren en tal manera que fynque para el dicho señor rey de cada una de las dichas cartas los dichos çiento e çinquenta mrs enteramente syn costa nin otro descuento alguno, segund dicho es, para lo qual asy tener e guardar e conplir e pagar e aver por firme obligó asy a sus bienes muebles e rayzes avidos e por aver como por mrs e aver del dicho señor rey, pero que sea entendido que sy todas las dichas cartas qu'él o otro por él asy resçibiere non se destribuyeren e gastaren, que de las cartas que d'ellas tornaren le sea fecho descargo o le sean resçibidos en cuenta los mrs que en ellas montaren por la forma e manera que le fueren cargados.

Otrosy se obligó que desde el dicho día que asy resçibiere las dichas cartas en adelante de tres en tres meses primeros siguientes traher o enbiar a vos los dichos contadores mayores copia çierta e verdadera con juramento que sobr'ello faga en manera que faga fe de todas las dichas cartas que fasta el dicho tienpo oviere dado e destribuydo por que podades d'ello ynformar al dicho señor rey e fazer çerca d'ello lo que cunple a su serviçio.

Otrosy se obligó que en el dicho cargo de la dicha reçebtoría se avrá bien e diligentemente, e que porná buenos pedricadores, los mejores que pudiere aver, tantos quantos bastaren para que se den e destribuyan las más cartas que ser pueda, por tal manera que por falta nin mengua nin ynigligençia de lo tal non venga nin venir pueda deserviçio al dicho señor rey e que andará e fará que anden e discurran los tales pedricadores e el otro o otros por él con ellos por todas las villas e lugares e sus tierras publicando e faziendo que se pedrique la dicha yndulgençia de la dicha Santa Cruzada, e poniendo en ello e sobr'ello aquel recabdo e acuçia e deligençia que a serviçio del dicho señor rey fuere conplidero.

Otrosy que dexará en cada villa o tierra a cargo suyo a personas Ilanas e contiosas cartas de la dicha yndulgençia, las que fuere menester, para los que las quisieren resçibir estando enfermos o en vida o para el artículo de la muerte la resçiban sy quisieren pagando el presçio que por ellas han de dar por tal manera qu'el serviçio de Dios sea más acresçentado e sea guardado el serviçio del dicho señor rey en ello.

Otrosy se obligó que non dará él <nin> otro por él, nin será en fabla nin en dicho nin consejo, que se den otras cartas de la dicha Cruzada, salvo las dichas cartas que asy resçibe e resçibiere de vos los dichos contadores mayores e que non tomará nin levará más de los dichos çinquenta mrs de cada una de las dichas cartas para lo que de susodicho es, e que en ello non fará nin consentirá que sea fecho nin se faga arte nin engaño nin encubierta alguna nin deserviçio del dicho señor rey e daño de la dicha Santa Cruzada.

Otrosy se obligó que fará publicar e pedricar la dicha Santa Cruzada por las dichas villas e tierras e que non consentirá nin dará lugar que se publique nin pedrique otra bulla nin ande otra demanda alguna, e que guardará e fará que sean guardadas e conplidas en todo su leal poder todas las otras cosas que son contenidas e se conternán en las cartas de poderes del dicho señor rey, e en las otras provisiones que sobre la dicha razón e en favor de la dicha Santa Cruzada por Su Alteza se han dado e librado e se dieren e libraren por vos los dichos contadores mayores.

Otrosy se obligó que non será en dicho nin en fecho nin en consejo que sea fecho nin se faga toma nin enbargo alguno en mrs algunos de la dicha yndulgençia nin dará a ello lugar direte nin yndirete, e sy fuere fallado que él fue o sopo o dio lugar a la tal toma o tomas, enbargo o enbargos, que por el mismo fecho non le sean resçibidos en cuenta los tales mrs, más antes que sea tenudo e obligado e se obligó de dar e pagar al dicho señor rey lo que montare la 
tal toma o enbargo con lo quatro tanto en dineros contados syn contradiçión alguna.

E obligose de tener e guardar e conplir todas las cosas susodichas e cada una d'ellas so pena de perdimiento de sus bienes e demás de las penas contenidas en la bulla del Santo Padre, e dio poder a las justiçias sobre sy e sobre los dichos sus bienes, los quales se obligó como por mrs e aver del dicho señor rey e en guarda d'ello renunçió todas las leyes e otorgó carta fuerte e firme ante mí el dicho Gonçalo Garçía qual paresçiere signada con mi signo e aparte d'esto fizo juramento en forma devida de non traher a pleito nin a rebuelta, e de pagar bien e llanamente e de tener e guardar las cosas suso dichas.

Fecha a catorze días de junio año del nasçimiento del nuestro señor Ihesu Christo de mill e quatroçientos e çinquenta e syete años. Gonçalo Garçía.

Testigos d'este recabdo: Lope Garçía, Alvar Gonçález de Llerena e Juan de la Fuente. [rúbrica] Gonçalo Garçía.

$<$ Recabdo Lope de Çaranes>

\section{DOCUMENTO 2}

Cantidades pagadas directamente por los receptores en concepto de sueldos militares con cargo al producto de la cruzada.

[1] Pagos de Diego Rodríguez de Dueñas, receptor del infantazgo de Valladolid ${ }^{200}$

\begin{tabular}{|l|l|}
\hline Destinatario y concepto & $\begin{array}{c}\text { Cuantía } \\
\text { (mrs) }\end{array}$ \\
\hline 1. $\begin{array}{l}\text { Alfón de Córdoba, escribano de cámara del } \\
\text { rey. Por nómina del rey firmada de su nombre } \\
\text { (1461-8-2), «a bueltas de otros en que enbió } \\
\text { mandar al dicho Rodrigo de Dueñas, thesorero } \\
\text { susodicho, e a Françisco de Valladolid, } \\
\text { trapero, su fiador, que de a Alfón de Córdova, } \\
\text { su escrivano de cámara, 50.000 mrs para } \\
\text { que d'ellos pague sueldo de çierto tienpo al }\end{array}$ & \\
arçobispo de Santiago e conde de Osorno e a \\
otras çiertas personas que por mandado del \\
dicho señor rey han estado e están en la villa de \\
Valladolid, e que tomen el traslado de la dicha \\
nómina e su carta de pago en las espaldas de los \\
mrs que así le dieren e pagaren»
\end{tabular}

200 AGS, EMR, leg. 8, ff. 1053-1054.

\begin{tabular}{|l|r|}
\hline \multicolumn{1}{|c|}{ Destinatario y concepto } & \multicolumn{1}{|c|}{$\begin{array}{c}\text { Cuantía } \\
\text { (mrs) }\end{array}$} \\
\hline 5. $\begin{array}{l}\text { Pero Méndez, vecino de Palencia. Por carta } \\
\text { de libramiento del rey (1461-12-2. Madrid), } \\
\text { «de sueldo para dos ginetes fasta que fue } \\
\text { despedido» }\end{array}$ & 2.016 \\
\hline 6. $\begin{array}{l}\text { Alfón García de Arévalo. Por carta de } \\
\text { libramiento del rey (1461-12-2. Madrid), «de } \\
\text { sueldo a conplimiento de lo que le montó aver } \\
\text { para tres lanças fasta que fue despedido» }\end{array}$ & 2.400 \\
\hline 7. $\begin{array}{l}\text { Gonzalo de Villafranca. Por carta de libramiento } \\
\text { del rey (1461-12-10. Madrid), «de sueldo» }\end{array}$ & 2.525 \\
\hline 8. Pero Niño. Por carta del rey (1461-11-30. & \\
Madrid) «de sueldo» & 6.068 \\
\hline 9. $\begin{array}{l}\text { Alonso de Arévalo, hijo de Alonso García. Por } \\
\text { carta (1461-12-2. Madrid) 438 mrs «de sueldo». } \\
\text { Nota al margen: «no pasó» [cantidad tachada] }\end{array}$ & \\
\hline [TOTAL] & [175.823] \\
\hline
\end{tabular}

[2] Pagos de García Martínez, receptor de las merindades de Rioja y Logroño 201

\begin{tabular}{|l|c|}
\hline \multicolumn{1}{|c|}{ Destinatario y concepto } & $\begin{array}{c}\text { Cuantía } \\
\text { (mrs) }\end{array}$ \\
\hline 10. $\begin{array}{l}\text { Antón de Baena, vasallo del rey. Para pagar } \\
\text { sueldo a la gente que estaba en Navarrete } \\
\text { por mandado del rey }\end{array}$ & 150.000 \\
\hline 11. Por un albalá del rey (1461-8-13) «que \\
lleve a la çibdat de Logroño çient mill mrs \\
e los de a Diego de Çetina, su escrivano de \\
cámara, para que d'ellos pague sueldo de \\
çierto tienpo a la gente de cavallo e de pie \\
$\begin{array}{l}\text { que está en su serviçio en çiertos castillos e } \\
\text { fortalezas del regno de Navarra» }\end{array}$ & 100.000 \\
\hline 12. Diego Arias Dávila, contador mayor del rey \\
y de su Consejo. Por carta de libramiento \\
del rey (1461-9-sd. Madrid), 100.000 mrs \\
«que los ovo de aver en cuenta del sueldo \\
que le es devido para las lanzas que ha \\
tenido en serviçio del dicho señor rey que \\
le fueron despedidas». Que tome su carta \\
de pago
\end{tabular}

201 AGS, EMR, leg. 8, ff. 941-942. 


\begin{tabular}{|c|c|}
\hline Destinatario y concepto & $\begin{array}{c}\text { Cuantía } \\
\text { (mrs) }\end{array}$ \\
\hline 16. Pedro Girón, maestre de Calatrava y del \\
$\begin{array}{l}\text { Consejo del rey. Por carta del rey (1461- } \\
\text { 11-28. Madrid) 800.000 mrs "que las ha } \\
\text { de aver en cuenta del sueldo que ovo de } \\
\text { aver para las IUD lanzas omes de armas e } \\
\text { de la gineta que tovo en serviçio del dicho } \\
\text { señor rey este dicho año, así en el reyno de } \\
\text { Navarra e en la frontera d'él como en otras } \\
\text { partes conplideras a su serviçio, desde que } \\
\text { las ayuntó fasta que fueron despedidas». }\end{array}$ \\
Que tome su carta de pago & \\
\hline [TOTAL] & 800.000 \\
\hline
\end{tabular}

[3] Pagos de Francisco Martínez de Cebreros, receptor de las merindades de Saldaña, Aguilar de Campoo, Liébana, Pernía, Carrión y su arcedianazgo, sin Paredes de Nava ${ }^{202}$

\begin{tabular}{|l|r|}
\hline \multicolumn{1}{|c|}{ Destinatario y concepto } & $\begin{array}{c}\text { Cuantía } \\
\text { (mrs) }\end{array}$ \\
\hline $\begin{array}{l}\text { 17. Por una carta nómina de libramiento del } \\
\text { rey (1461-9-18. Illescas), que comienza } \\
\text { en Alonso de Córdoba y acaba en Alonso } \\
\text { de Padilla en 203 mrs, 9.177 mrs para } \\
\text { que recuda con ellos a las personas allí } \\
\text { contenidas, "que los ovieron de aver de } \\
\text { sueldo» }\end{array}$ & 9.177 \\
\hline 18. $\begin{array}{l}\text { Don Juan Arias, obispo de Segovia. Por } \\
\text { carta de libramiento (1461-9-18. Illescas) } \\
\text { «que los ovo de aver de sueldo para XXI } \\
\text { lanzas e ginetes» }\end{array}$ & 22.844 \\
\hline 19. $\begin{array}{l}\text { Martín de Valduerna, vasallo del rey. Por } \\
\text { carta (1461-9-3. Madrid), 4.000 mrs «de } \\
\text { su tierra e acostamiento para dos lanças } \\
\text { d'este dicho año», para que le de la mitad } \\
\text { en fin de diciembre y la otra mitad en fin } \\
\text { de enero }\end{array}$ & \\
\hline 20. Pedro de Torres, vasallo del rey, vecino de \\
Cáceres. Por carta (1461-11-30) & 4.000 \\
\hline 21. Juan Martínez de Cebreros, vecino de Ávila. \\
$\begin{array}{l}\text { Por carta (1461-12-12. Madrid), de cierto } \\
\text { sueldo que debía recibir por un jinete }\end{array}$ & 22.109 \\
\hline [TOTAL] & [60.230] \\
\hline
\end{tabular}

[4] Pagos del receptor Diego González [de Ágreda] ${ }^{203}$

\begin{tabular}{|c|c|}
\hline Destinatario y concepto & $\begin{array}{c}\text { Cuantía } \\
\text { (mrs) }\end{array}$ \\
\hline $\begin{array}{l}\text { 22. Don Pedro, obispo de Osma. Por carta de } \\
\text { libramiento del rey (1461-12-2. Madrid), } \\
\text { «en cuenta del sueldo que ovo de aver } \\
\text { para las lanças que traya en la guarda fasta } \\
\text { que le fueron despedidas» }\end{array}$ & 16.000 \\
\hline $\begin{array}{l}\text { 23. Diego González Mercadal, tesorero. Por } \\
\text { carta de libramiento del rey (1461-12-10. } \\
\text { Madrid), de su acostamiento para dos } \\
\text { lanzas que debía recibir este año }\end{array}$ & 4.000 \\
\hline
\end{tabular}

\begin{tabular}{|c|c|}
\hline Destinatario y concepto & $\begin{array}{c}\text { Cuantía } \\
\text { (mrs) }\end{array}$ \\
\hline $\begin{array}{l}\text { 24. Don Rodrigo Pimentel, conde de } \\
\text { Benavente. Por carta de libramiento del rey } \\
\text { (1462-3-25. Madrid), en cuenta de } 100.000 \\
\text { mrs que el rey le mandó librar de su ayuda } \\
\text { de costa y de cierto sueldo de cinco meses } \\
\text { «que agora estovo en su serviçio» }\end{array}$ & 20.000 \\
\hline $\begin{array}{l}\text { 25. Gonzalo de Miranda, vecino de Soria. Por } \\
\text { carta del rey (1462-4-28. Madrid), de su } \\
\text { acostamiento de } 1461 \text { para ocho lanzas }\end{array}$ & 16.000 \\
\hline $\begin{array}{l}\text { 26. Juan de Aguilar. Por carta (1462-9-9. } \\
\text { Ágreda), "que los ovo de aver de sueldo } \\
\text { para dos lanças fasta en fin de setienbre } \\
\text { de LXI» }\end{array}$ & 1.998 \\
\hline [TOTAL] & [57.998] \\
\hline
\end{tabular}

[5] Pagos de Juan Sánchez de Salinas, receptor del condado y señorío de Vizcaya, con las Encartaciones, la Provincia de Guipúzcoa y la merindad de Allendebro ${ }^{204}$

\begin{tabular}{|l|c|}
\hline Destinatario y concepto & $\begin{array}{c}\text { Cuantía } \\
\text { (mrs) }\end{array}$ \\
\hline 27. Antón de Baena. Por carta del rey (1460- & \\
4-8) «para pagar el sueldo a la gente que \\
estava en Navarra» & 150.000 \\
\hline 28. Por nómina del rey (1461-8-2) «a bueltas & \\
de otros en que enbió mandar al dicho \\
Juan Sánchez de Salinas, thesorero \\
susodicho, que de a Alonso de Córdova, \\
su escrivano de cámara, dozientas mill mrs \\
para que d'ellos pague sueldo de çierto \\
tienpo al arçobispo de Santiago e conde \\
de Osorno, e otros cavalleros e personas & \\
que por mandado del dicho señor rey han \\
estado e están en la villa de Valladolid, e \\
que tome el traslado de la dicha nómina \\
signado e su carta de pago en las espaldas \\
d'ella de los mrs que así le diere e pagare \\
fasta las dichas CCU e non más». Nota al \\
margen: «no los ha de pagar» \\
\hline 29. Por albalá del rey (1461-8-13) «que lleve \\
a la çibdad de Logroño treynta e siete \\
mill mrs que los de a Diego de Çetina, su \\
escrivano de cámara, para que d'ellos \\
pague sueldo de çierto tienpo a la gente de \\
cavallo e de pie que está en su serviçio en \\
çiertos castillos e fortalezas del regno de \\
Navarra e que tome su carta de pago»
\end{tabular}




\begin{tabular}{|l|r|}
\hline Destinatario y concepto & $\begin{array}{c}\text { Cuantía } \\
\text { (mrs) }\end{array}$ \\
\hline 31. $\begin{array}{l}\text { Por albalá del rey (1461-9-29) «que lleve a } \\
\text { la çibdat de Logroño 124.200 mrs e los de } \\
\text { a Diego de Çetina, su escrivano de cámara, } \\
\text { para que d'ellos pague sueldo a la dicha } \\
\text { gente de cavallo e de pie que está en los } \\
\text { dichos castillos de Navarra» }\end{array}$ & 124.200 \\
\hline 32. $\begin{array}{l}\text { Capitán Íñigo Ortiz de Estúñiga. Por carta } \\
\text { de libramiento del rey (1461-10-2. Madrid) } \\
\text { "que los ovo de aver de sueldo de çinco } \\
\text { días para çierta gente de cavallo e de pie } \\
\text { que tovo ayuntada por mandado del rey } \\
\text { este dicho año, e que recuda con ellos al } \\
\text { dicho mariscal e ge los de luego» }\end{array}$ & 13.547 \\
\hline 33. $\begin{array}{l}\text { Diego de Çetina, guarda y vasallo del rey. } \\
\text { Por carta del rey (1461-10-6) «para que } \\
\text { d'ellos pague sueldo a la gente que ha } \\
\text { estado e está e estoviere en serviçio del } \\
\text { dicho señor rey en el reyno de Navarra». } \\
\text { «Dale poder para los cobrar del dicho Juan } \\
\text { Sánchez e de sus fiadores» }\end{array}$ & 100.000 \\
\hline 34. Juan de Deza. Por carta del rey (1461-12-2. \\
Madrid) «de sueldo»
\end{tabular}

[6] Pagos de Fernando Díaz de Alcocer, receptor del arcedianazgo de Guadalajara ${ }^{205}$

\begin{tabular}{|c|c|}
\hline Destinatario y concepto & $\begin{array}{c}\text { Cuantía } \\
\text { (mrs) }\end{array}$ \\
\hline $\begin{array}{l}\text { 37. Don Pedro, obispo de Osma. Por carta del } \\
\text { rey (1461-10-3. Madrid), } 12.730 \mathrm{mrs} \text { "que } \\
\text { le montó aver de sueldo para la gente que } \\
\text { llevó a la frontera de Navarra» }\end{array}$ & 12.730 \\
\hline $\begin{array}{l}\text { 38. Don Pedro, obispo de Osma. Por carta del } \\
\text { rey (1461-10-3. Madrid), } 19.882 \mathrm{mrs} \text { «de } \\
\text { sueldo para veynte lanzas de guarda fasta } \\
\text { fin de agosto» }\end{array}$ & 19.882 \\
\hline $\begin{array}{l}\text { 39. Juan de Rueda. Por carta del rey (1461-11- } \\
\text { 30. Madrid), } 3.871 \text { mrs «a conplimiento del } \\
\text { sueldo que le montó aver para tres ginetas } \\
\text { fasta que fue despedido» }\end{array}$ & 3.871 \\
\hline $\begin{array}{l}\text { 40. Gonzalo de León. Por carta del rey (1461- } \\
\text { 12-6. Madrid), } 4.000 \text { mrs «de su tierra e } \\
\text { acostamiento para dos lanças d'este año» }\end{array}$ & 4.000 \\
\hline $\begin{array}{l}\text { 41. Don Pedro, obispo de Osma. Por carta de } \\
\text { libramiento del rey (1461-12-2. Madrid), } \\
16.440 \text { mrs «en cuenta del sueldo que ovo } \\
\text { de aver para las veynte lanzas que tenya en } \\
\text { la guarda fasta que le fueron despedidas» }\end{array}$ & 16.440 \\
\hline $\begin{array}{l}\text { 42. Ortuño de "Cuçibay». Por carta del rey } \\
\text { (1461-12-2. Madrid), } 4.412 \mathrm{mrs} \text { "de } \\
\text { sueldo para quatro ginetas fasta que fue } \\
\text { despedido» }\end{array}$ & 4.412 \\
\hline
\end{tabular}

\begin{tabular}{|c|c|}
\hline Destinatario y concepto & $\begin{array}{l}\text { Cuantía } \\
\text { (mrs) }\end{array}$ \\
\hline $\begin{array}{l}\text { 43. García de Alcocer. Por carta del rey (1461- } \\
\text { 12-2. Madrid), } 3.588 \mathrm{mrs} \text { «de sueldo» }\end{array}$ & 3.588 \\
\hline $\begin{array}{l}\text { 44. Don Martín de Luna. Por carta del rey } \\
\text { (1461-12-2. Madrid), } 4.565 \mathrm{mrs} \text { "de } \\
\text { sueldo» }\end{array}$ & 4.565 \\
\hline $\begin{array}{l}\text { 45. Martín de Mirones. Por carta del rey (1461- } \\
\text { 11-30. Madrid), } 3.877 \text { mrs de sueldo }\end{array}$ & 3.877 \\
\hline $\begin{array}{l}\text { 46. Pedro de Tostaros. Por carta del rey (1461- } \\
\text { 12-12. Madrid), } 2.105 \text { mrs de sueldo }\end{array}$ & 2.105 \\
\hline $\begin{array}{l}\text { 47. Ruy Jorge, criado de «Brecaydal». Por carta } \\
\text { del rey (1461-12-2. Madrid), } 1.957 \text { mrs de } \\
\text { sueldo }\end{array}$ & 1.957 \\
\hline $\begin{array}{l}\text { 48. Juan de Quetaria y Diego de Quetaria, } \\
\text { criados del alcalde de [टं?]. Por carta del rey } \\
\text { (1461-12-12. Madrid), de sueldo }\end{array}$ & 5.400 \\
\hline $\begin{array}{l}\text { 49. Juan de Morales, vecino de Soria. Por carta } \\
\text { del rey (1461-12-12. Madrid), de sueldo }\end{array}$ & 2.504 \\
\hline $\begin{array}{l}\text { 50. Juan de Quebedo. Por carta del rey (1461- } \\
\text { 12-2. Madrid), de sueldo }\end{array}$ & 5.577 \\
\hline $\begin{array}{l}\text { 51. García de Alcocer. Por carta del rey (1461- } \\
\text { 12-20. Madrid), de sueldo hasta que fue } \\
\text { despedido }\end{array}$ & 1.622 \\
\hline $\begin{array}{l}\text { 52. Gonzalo de Olmedo, Juan de Medina y } \\
\text { Juan de Arévalo, vasallos del rey. Por carta } \\
\text { del rey (1465-12-18. Segovia), «en cuenta } \\
\text { del sueldo que les es devido para cada } \\
\text { tres lanças con pajes que han tenido en su } \\
\text { serviçio este dicho año» }\end{array}$ & 21.300 \\
\hline $\begin{array}{l}\text { 53. Martín de Córdoba, Pedro López de Toledo } \\
\text { y Pedro de Córdoba, vasallos del rey. Por } \\
\text { carta del rey (1465-12-18. Segovia), «en } \\
\text { cuenta del sueldo de otras tres lanzas del } \\
\text { dicho año» }\end{array}$ & 24.500 \\
\hline TOTAL & 138.330 \\
\hline
\end{tabular}

[7] Pagos de Diego de Alcalá, receptor del obispado de Cartagena y reino de Murcia ${ }^{206}$

\begin{tabular}{|c|c|}
\hline Destinatario y concepto & $\begin{array}{c}\text { Cuantía } \\
\text { (mrs) }\end{array}$ \\
\hline $\begin{array}{l}\text { 54. Marqués de Villena [don Juan Pacheco]. } \\
\text { Por carta de libramiento del rey (1461- } \\
\text { 12-5. Madrid), «en cuenta del sueldo para } \\
\text { çiento e çinquenta lanzas que tovo este } \\
\text { dicho año en serviçio del dicho señor rey e } \\
\text { por su mandado en la villa de Ocaña fasta } \\
\text { XXVII de agosto que fueron despedidas, e } \\
\text { que ge los de luego en dineros contados e } \\
\text { tome su carta de pago» }\end{array}$ & 121.795 \\
\hline $\begin{array}{l}\text { 55. Marqués de Villena [don Juan Pacheco]. } \\
\text { Por carta de libramiento del rey (1461- } \\
\text { 12-5. Madrid), "en cuenta de su sueldo } \\
\text { para otras çinquenta lanzas que traya } \\
\text { en la guarda este dicho año fasta XXV de } \\
\text { novienbre que las XXX d'ellas le fueron } \\
\text { despedidas, e ge os de segund dicho es e } \\
\text { tome su carta de pago» }\end{array}$ & 73.022 \\
\hline
\end{tabular}




\begin{tabular}{|c|c|}
\hline Destinatario y concepto & $\begin{array}{l}\text { Cuantía } \\
\text { (mrs) }\end{array}$ \\
\hline $\begin{array}{l}\text { 56. Marqués de Villena [don Juan Pacheco]. } \\
\text { Por carta de libramiento del rey (1461- } \\
\text { 12-5. Madrid), "en cuenta de su sueldo } \\
\text { para quatro lanzas e CL peones que tovo } \\
\text { este dicho año contra Alonso Fajardo fasta } \\
\text { XXIII de otubre que çiertas d'ellas le fueron } \\
\text { despedidas e ge los de segund de suso, e } \\
\text { tome su carta de pago». Nota al margen: } \\
\text { "diose sobrecarta del rey nuestro señor } \\
\text { dada en Madrid a dos de enero de LXII } \\
\text { contra el dicho Diego de Alcalá, reçebtor, e } \\
\text { contra Alonso Gómez de Castro, vezino de } \\
\text { Uclés, su fiador de mancomún» }\end{array}$ & 109.235 \\
\hline $\begin{array}{l}\text { 57. Don Lope de Barrientos, obispo de Cuenca. } \\
\text { Por carta del rey (1461-11-4. Medina del } \\
\text { Campo) «de su acostamiento d'este año». } \\
\text { Debe recibirlos por tercios }\end{array}$ & 40.000 \\
\hline $\begin{array}{l}\text { 58. Diego de la ¿ं?. Por carta del rey (1461-12- } \\
\text { 2. Madrid) «de sueldo» }\end{array}$ & 3.877 \\
\hline $\begin{array}{l}\text { 59. Diego de Pada. Por carta (1461-12-12. } \\
\text { Madrid) «de su sueldo para dos lanças» }\end{array}$ & 2.500 \\
\hline $\begin{array}{l}\text { 60. Juan de Guzmán, «cuya es Teba». Por carta } \\
\text { (1462-1-17. Madrid), «de sueldo que ovo } \\
\text { de aver para quinze ginetes fasta que fue } \\
\text { despedido». Nota al margen: «Diose carta } \\
\text { ejecutoria contra el dicho Diego de Alcalá } \\
\text { para que pague al dicho Juan de Guzmán } \\
\text { los dichos VIUXXII mrs fecha tres días de } \\
\text { setienbre de LXII» }\end{array}$ & 6.022 \\
\hline $\begin{array}{l}\text { 61. Comendador Gonzalo Rodríguez de } \\
\text { Ledesma. Por carta de libramiento del } \\
\text { rey (1462-4-11. Madrid) «que los ovo de } \\
\text { aver de sueldo para quatro cavalleros e } \\
\text { diez peones qu'él por mandado del rey } \\
\text { ha de tener en el abadía qu'es çerca de } \\
\text { Granadilla» }\end{array}$ & 42.542 \\
\hline $\begin{array}{l}\text { 62. Comendador Gonzalo Rodríguez de } \\
\text { Ledesma. Por carta de libramiento del rey } \\
\text { (1462-4-11. Madrid) "que los ovo de aver } \\
\text { de su merçed que d'el rey tiene este dicho } \\
\text { año» }\end{array}$ & 31.800 \\
\hline $\begin{array}{l}\text { 63. Comendador Gonzalo Rodríguez de } \\
\text { Ledesma. Por carta de libramiento del } \\
\text { rey (1462-4-11. Madrid) "de su raçión e } \\
\text { quitaçión e tasa que ovo de aver este dicho } \\
\text { año» }\end{array}$ & 17.800 \\
\hline [TOTAL] & [448.593] \\
\hline
\end{tabular}

\section{BiBLIOGRAFÍA}

Abad Raúl, V. 2008. Los libros de Actas Capitulares de la Catedral de Salamanca (1298-1489). Salamanca: Cabildo Catedral de Salamanca.

Abellán Pérez, J. s/a. Fuentes históricas jerezanas: documentos de Enrique IV de Castilla (1454-1474). s. I.: Libros EPCCM.

Álvarez Rubiano, P. 1944. Pedrarias Dávila. Contribución al estudio de la figura del "Gran Justador», gobernador de Castilla del Oro y Nicaragua. Madrid: CSIC-Instituto Gonzalo Fernández de Oviedo.

Arranz Guzmán, A. 2006. «El episcopado y la guerra contra el infiel en las Cortes de la Castilla Trastámara», en J. M. Nieto Soria (dir.), La monarquía como conflicto en la Corona castellano-leonesa (c. 1230-1504): 253-297. Madrid: Sílex.
Asenjo González, M. 1986. Segovia: la ciudad y su tierra a fines del Medievo. Segovia: Excma. Diputación Provincial de Segovia-Excmo. Ayuntamiento de Segovia-Universidad Complutense de Madrid.

Baloup, D. 2003. "La prédication des indulgences et les quêtes itinérantes dans le royaume de Castille aux derniers siècles du Moyen Âge», en S. Cassagnes-Brouquet, A. Chauou, D. Pichot y L. Sousselot (eds.), Religion et mentalités au Moyen Âge. Mélanges en I'honneur 'Hervé Martin: 315-323. Rennes: Presses Universitaires de Rennes.

Baloup, D. 2003-2004. "La muerte y la penitencia en la predicación de las indulgencias en Castilla a finales de la Edad Media». Edad Media: revista de historia 6: 61-89.

Barrientos, L. 1946. Refundición de la Crónica del Halconero. Madrid: Espasa Calpe. [Ed. J. M. Carriazo].

Batllori, M. 1999. La familia de los Borjas. Madrid: Real Academia de la Historia.

Benito Ruano, E. 1960. «Granada o Constantinopla». Hispania 20/70: 267-314.

Cantera Burgos, F. 1969. La familia judeoconversa de los Cota de Toledo. Madrid: Academia de Doctores de Madrid.

Cantera Burgos, F. 1971. Pedrarias Dávila y Cota, Capitán general de Castilla del Oro y Nicaragua: sus antecedentes judíos. Madrid: Universidad.

Cañas Gálvez, F. P. 2012. Burocracia y cancillería en la corte de Juan Il de Castilla (1406-1454). Estudio institucional y prosopográfico. Salamanca: Universidad de Salamanca.

Carceller Cerviño, M. P. 2006. Realidad y representación de la nobleza castellana del siglo XV. El linaje de la Cueva y la Casa ducal de Alburquerque. Tesis doctoral. Madrid: Universidad Complutense de Madrid.

Carrasco Manchado, A. I. 2006. «Símbolos y ritos: el conflicto como representación», en J. M. Nieto Soria (dir.), La monarquía como conflicto en la corona castellano-leonesa (c. 1230-1504): 489-546. Madrid: Sílex.

Carriazo y Arroquia, J. M. (ed.) 1982. Crónica de Juan II de Castilla. Madrid: Real Academia de la Historia.

Carriazo, J. M. (ed.) 1940. Crónica de Don Álvaro de Luna. Madrid: Espasa-Calpe.

Carrillo de Huete, P. 1946. Crónica del halconero de Juan II. Madrid: Espasa Calpe. [J. M. Carriazo (ed.)].

Castro Toledo, J. 1981. Colección diplomática de Tordesillas, 909-1474. Valladolid: Servicio de Publicaciones de la Diputación Provincial de Valladolid.

Caunedo del Potro, B. 1998. «Factores burgaleses, ¿privilegiados o postergados?». En la España medieval 21: 97-114.

Causse, B. 1988. Église, finance et royautè. La floraison des decimes dans la France du Moyen Âge. Paris: ANRT.

Collantes de Terán Sánchez, A. 2000. "La élite financiera en la Sevilla bajomedieval: los mayordomos del concejo». Revista d'Història Medieval 11: 13-40.

Conde de Valencia de Don Juan. 1898. Catálogo histórico-descriptivo de la Real Armería de Madrid. Madrid: Estab. Tip. Sucesores de Rivadeneyra.

Corradini, S. 2006. «Preparazione della crociata contro il turco e tramonto di un sogno di Pio II», en R. di Paola, A. Antoniutti y M. Gallo (ed.), Enea Silvio Piccolomini. Arte, storia e cultura nell'Europa di Pio II: 263-278. Roma: Associazione culturale Shakespeare 2.

Cuevas Mata, J y Arco Moya, J. del (eds.) 2001. Relación de los hechos del muy magnífico e más virtuoso señor, el señor don Miguel Lucas, muy digno condestable de Castilla. Jaén: Ayuntamiento de JaénUniversidad de Jaén.

Echevarría Arsuaga, A. 2004. «Enrique IV, un rey cruzado». Espacio, Tiempo y Forma. Serie III. Historia Medieval 17: 143-156.

Enríquez del Castillo, D. 1878. «Crónica de Enrique IV», en Crónicas de los reyes de Castilla. Vol. 70. Madrid: BAE.

Enríquez del Castillo, D. 1994. Crónica de Enrique IV. Valladolid: Universidad de Valladolid. [Ed. A. Sánchez Martín].

Fabié, A. M. 1879. Viajes por España de Jorge de Einghen, del Barón Leon de Rosmithal de Blatna, de Francisco Guicciardini y de Andrés Navajero. Madrid: Fernando Fé. 
Fernández Gallardo, L. 2010. «Guerra santa y cruzada en el ciclo cronístico de Alfonso XI». En la España Medieval 33: 43-74.

Fernández Gallardo, L. 2014. «Imágenes del Turco en la Castilla del siglo XV», en J. M. Nieto Soria y Ó. Villarroel González (coords.), Pacto y consenso en la cultura política peninsular. Siglos XI al XV: 459-495. Madrid: Sílex.

Foronda, F. 2003. "Le prince, le palais et la ville. Ségovie ou le visage du tyran dans la Castille du XV siècle». Revue historique 627: 521-542.

Galíndez de Carvajal, L. 1946. Crónica de Enrique IV. Murcia: CSIC-Seminario de Historia de la Universidad de Murcia. [Ed. J. Torres Fontes].

García de Cortázar y Ruiz de Aguirre, J. Á. 1979. Introducción a la historia medieval de Álava, Guipúzcoa y Vizcaya en sus textos. San Sebastián: Txertoa.

Gil, J. 2003. Los conversos y la Inquisición sevillana. Vol. VI. El distrito y sus hombres. Sevilla: Universidad de Sevilla-Fundación El Monte.

Giménez Soler, A. 1908. "La Corona de Aragón y Granada». Butlletí de la Reial Acadèmia de Bones Lletres de Barcelona 4/30: 342-375.

Goicolea Julián, F. J. 2002. Archivo Municipal de Salvatierra-Agurain. Vol. III (1451-1500). Donostia: Sociedad de Estudios Vascos.

González González, R. 2015. «Vida, industria y tribulaciones de Juan de Oviedo, recaudador mayor de Asturias (C. 1406-1494)», en E. García Fernández, y J. A. Bonachía Hernando (eds.), Hacienda, mercado y poder al norte de la Corona de Castilla en el tránsito del Medievo a la Modernidad: 291-323. Valladolid: Castilla Ediciones.

González Sánchez, S. 2013. Las relaciones exteriores de Castilla a comienzos del siglo XV. La minoría de Juan II (1407-1420). Madrid: Comité Español de Ciencias Históricas.

Goñi Gazambide, J. 1980. «Estado actual de los estudios sobre Pedro Martínez de Osma». Celtiberia 30/59: 5-35.

Goñi Gaztambide, J. 1954. «Las primeras indulgencias de difuntos (1456-1474)». Anthologica annua 2: 377-391.

Goñi Gaztambide, J. 1958. Historia de la bula de la cruzada en España. Vitoria: Editorial del Seminario.

Grau, M. 1949. "Así fue coronada Isabel la Católica». Estudios Segovianos 1: 20-39.

Guerrero Navarrete, Y. 1986. Organización y gobierno en Burgos durante el reinado de Enrique IV de Castilla (1453-1476). Madrid: Universidad Autónoma de Madrid.

Guerrero Navarrete, Y. 2013. «Ser y pertenecer a la élite: estrategias de reproducción del poder en el Burgos bajomedieval», en J. A. Jara Fuente (coord.), Ante su identidad: la ciudad hispánica en la Baja Edad Media: 75-92. Cuenca: Universidad de Castilla-La Mancha.

Kirschberg Schenck, D. 2012. Catálogo de los Papeles del Mayordomazgo del siglo XV. Vol. V (1455-1474). Sevilla: Ayuntamiento de Sevilla.

Ladero Quesada, M. Á. 1991. «1462: un año en la vida de Enrique IV, rey de Castilla». En la España medieval 14: 237-274.

Ladero Quesada, M. Á. 2002. Las guerras de Granada en el siglo XV. Barcelona: Ariel.

Ladero Quesada, M. Á. 2009a. "La Hacienda Real de Castilla en el siglo XV», en La Hacienda Real de Castilla (1369-1504). Estudios y documentos: 1-400. Madrid: Real Academia de la Historia.

Ladero Quesada, M. Á. 2009b. "El cargo de Diego Arias en 1462», en La Hacienda Real de Castilla (1369-1504). Estudios y documentos: 543-559. Madrid: Real Academia de la Historia.

Ladero Quesada, M. Á. 2009c. "Para una imagen de Castilla (14291504)", La Hacienda Real de Castilla (1369-1504). Estudios y documentos: 487-505. Madrid: Real Academia de la Historia.

Ladero Quesada, M. Á. 2011. Fiscalidad y poder real en Castilla. Madrid: Real Academia de la Historia.

López Rodríguez, C. (dir.) 2007. Diplomatari Borja. Vol. 4. Documents de l'Arxiu de la Corona d'Aragó (1444-1458). Valéncia: Edicions 3i4.

Martín Expósito, A. y Monsalvo Antón, J. M. 1986. Documentación medieval del Archivo Municipal de Ledesma. Salamanca: Ediciones de la Diputación de Salamanca.

Martín Martín, J. L. 2002. Enrique IV de Castilla. Rey de Navarra, Príncipe de Cataluña. Madrid: Hondarribia.

Medina y Mendoza, F. 1853. «Vida del Cardenal D. Pedro González de Mendoza», en Memorial Histórico Español: vol. VI, 153-310. Madrid: Real Academia de la Historia.
Memorias de don Enrique IV de Castilla. Vol. II. Colección diplomática. 1835-1913. Madrid: Real Academia de la Historia.

Molina Grande, M. C. 1988. Documentos de Enrique IV. Murcia: Academia Alfonso X El Sabio.

Morelló i Baget, J. (coord.) 2013. Financiar el reino terrenal: la contribución de la iglesia a finales de la Edad Media (siglos XIII-XVI). Barcelona: CSIC.

Navarro Sorní, M. 2004. "Calixto III y la cruzada contra el Turco», en M. Chiabò, A. M. Oliva y O. Schena (eds.), Alessandro VI dal Mediterraneo all'Atlantico. Atti del convegno (Cagliari, 17-19 maggio 2001): 147-167. Roma: Ministero per i Beni e le Attività Culturali-Direzione Generale per gli Archivi.

Navarro Sorní, M. 2008a. Alfonso de Borja, Papa Calixto III en la perspectiva de sus relaciones con Alfonso el Magnánimo. Valencia: Institució Alfons el Magnánim.

Navarro Sorní, M. 2008b. Documents per a la història d'Alfons de Borja, Papa Calixt III. Valéncia: Institució Alfons el Magnànim-Diputació de València.

Nieto Soria, J. M. 1988a. Iglesia y poder real en Castilla. El episcopado.1250-1350. Madrid: Editorial Complutense.

Nieto Soria, J. M. 1988b. Fundamentos ideológicos del poder real en Castilla (siglos XIII-XVI): 80-81. Madrid: Eudema.

Nieto Soria, J. M. 1993. Iglesia y génesis del Estado moderno en Castilla. Madrid: Editorial Complutense.

Nieto Soria, J. M. 1994. «El pontificado de Martín V y la ampliación de la soberanía real sobre la Iglesia castellana (1417-1431)». En la España Medieval 17: 113-131.

Nieto Soria, J. M. 1996. «Enrique IV de Castilla y el Pontificado (14541474)». En la España Medieval 19: 167-238.

Nieto Soria, J. M. 2010. «El ciclo ceremonial de la batalla de la Higueruela (1431)». Estudios de Historia de España (Homenaje a María del Carmen Carlé en sus 90 años) 12 (2): 389-404.

Nieto Soria, J. M. 2012a. «La ceremonialización de la vida política durante la regencia de Fernando de Antequera (1406-1416)», en Mundos medievales: espacios, sociedades y poder. Homenaje al profesor José Ángel García de Cortázar y Ruiz de Aguirre: II, 16871698. Santander: Universidad de Cantabria.

Nieto Soria, J. M. 2012b. «El pregón real en la vida política de la Castilla trastámara». Edad Media: revista de historia 13: 77-102.

Nieto Soria, J. M. 2015. De Enrique IV al emperador Carlos. Crónica anónima castellana de 1454 a 1536. Madrid: Sílex.

O'Callaghan, J. F. 2011. The Gibraltar Crusade. Castile and the Battle for the Strait. Philadelphia: University of Pennsylvania Press.

O'Callaghan, J. F. 2014. The last crusade in the West: Castile and the conquest of Granada. Philadelphia: University of Pennsylvania Press.

Olivera Serrano, C. 1986. Las Cortes de Castilla y León y la crisis del reino (1445-1474): el registro de Cortes. Burgos: Cortes de Castilla y León.

Ortego Rico, P. 2015. Poder financiero y gestión tributaria en Castilla: los agentes fiscales en Toledo y su reino (1429-1504). Madrid: Instituto de Estudios Fiscales.

Ortiz de Zúñiga, D. 1796. Anales eclesiásticos y seculares de la muy noble y muy leal ciudad de Sevilla, metrópoli de la Andalucía. Madrid: Imprenta Real.

Otte, E. 1996. Sevilla y sus mercaderes a fines de la Edad Media. Sevilla: Vicerrectorado de Relaciones Institucionales y Extensión Cultural. [Eds. A.-M. Bernal, A. Collantes de Terán].

Palencia, A. 1973. Crónica de Enrique IV. Madrid: Atlas. [Ed. A. Paz y Melia].

Palencia, A. 1999. Gesta Hispaniensia ex annalibvs svuorvm diarvm collecta. Tomo 2. Libri VI-X. Madrid: Real Academia de la Historia. [Eds. B. Tate y J. Lawrance].

Porras Arboledas, P. A. 2006. «Un protocolo ubetense de 1459 y otros documentos procesales de los siglos XV y XVI». Cuadernos de Historia del Derecho 13: 311-345.

Pulgar, F. 1943. Crónica de los Reyes Católicos. Madrid: Espasa-Calpe. [ed. J. M. Carriazo]. 
Rábade Obradó, M. P. 1990. «El doctor Juan Díaz de Alcocer. Apuntes biográficos de un servidor de los Reyes Católicos». Espacio. Tiempo. Forma. Serie III. Historia Medieval 3: 259-288.

Rábade Obradó, M. P. 2009. «Escenario para una Corte real: Madrid en tiempos de Enrique IV». e-Spania: Revue électronique d'études hispaniques médiévales: 8.

Rius Serra, J. 1948. Regesto ibérico de Calixto III. Barcelona: CSIC Escuela de Estudios Medievales.

Rubio Martínez, A. 2010. «La Hacienda Real de Galicia en la época de Enrique IV». En la España Medieval 33: 97-130.

Rumeu de Armas, A. 1969. La política indigenista de Isabel la Católica. Valladolid: Instituto «Isabel la Católica» de Historia eclesiástica.

Salicrú i Lluch, R. 1998. El sultanat de Granada i la Corona d'Aragó (1410-1458). Barcelona: CSIC.

Salicrú i Lluch, R. 2004. "Caballeros cristianos en el Occidente europeo e islámico», en K. Herbers y N. Jaspert (eds.), Das kommt mir spanisch vor. Eigenes und Fremdes in den deutsch-spanischen Beziehungen des späten Mittelalters: 217-289. Münster: Lit.

Sánchez Parra, M. P. (ed.) 1991. Crónica anónima de Enrique IV de Castilla. Madrid: Ediciones de la Torre.

Suárez Fernández, L. 2001. Enrique IV de Castilla. La difamación como arma política. Barcelona: Ariel.

Torija Rodríguez, E. 2012. «El Subsidio Eclesiástico para la guerra de Granada (1482-1492). Aportación, ingresos y gastos en el arzobispado de Toledo». Medievalismo 22: 217-238.
Torres Fontes, J. 2001. Fajardo el Bravo. Murcia: Real Academia Alfonso $\mathrm{X}$ el Sabio.

Torres Fontes, J. s/a. Itinerario de Enrique IV de Castilla. Murcia: Universidad de Murcia.

Triano Milán, J. M. 2015. El aparato financiero de la Santa Hermandad en Sevilla y su alfoz. Tesis de licenciatura. Universidad de Málaga.

Valentini, G. 1974. «La Crociata da Eugenio IV a Callisto III (dai documenti d'archivio di Venezia)». Archivium Historiae Pontificale 12: 91-123.

Valentini, G. 1975. «La crociata di Pio II dalla documentazione veneta d'archivio». Archivium Historiae Pontificale 13: 249-282.

Valera, D. 1941. Memorial de diversas hazañas. Madrid: Espasa-Calpe. [Ed. J. M. Carriazo].

Villarroel González, Ó. 2000. «El papado y la monarquía de Juan II de Castilla (1406-1454) en un inventario de documentación pontificia de los Reyes Católicos». En la España medieval 23: 137-187.

Villarroel González, Ó. 2011. El rey y la Iglesia castellana. Relaciones de poder con Juan II (1406-1454). Madrid: Fundación Ramón Areces.

Villarroel González, Ó. 2013. «La tributación de los eclesiásticos castellanos en el siglo XV: entre el rey y el papa», en J. Morelló i Baget (coord.), Financiar el reino terrenal: la contribución de la iglesia a finales de la Edad Media (siglos XIII-XVI): 315-343. Barcelona: CSIC. 